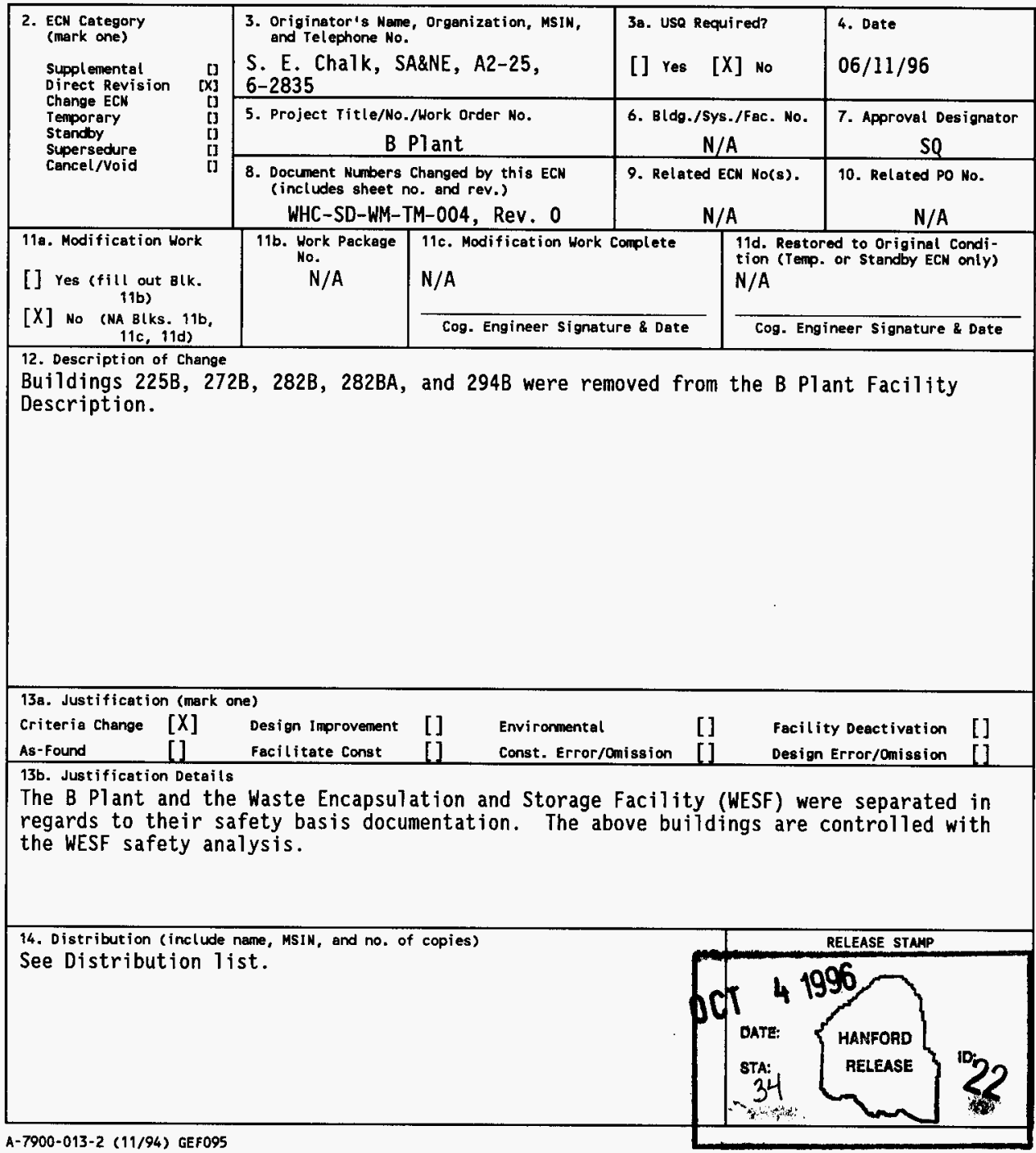




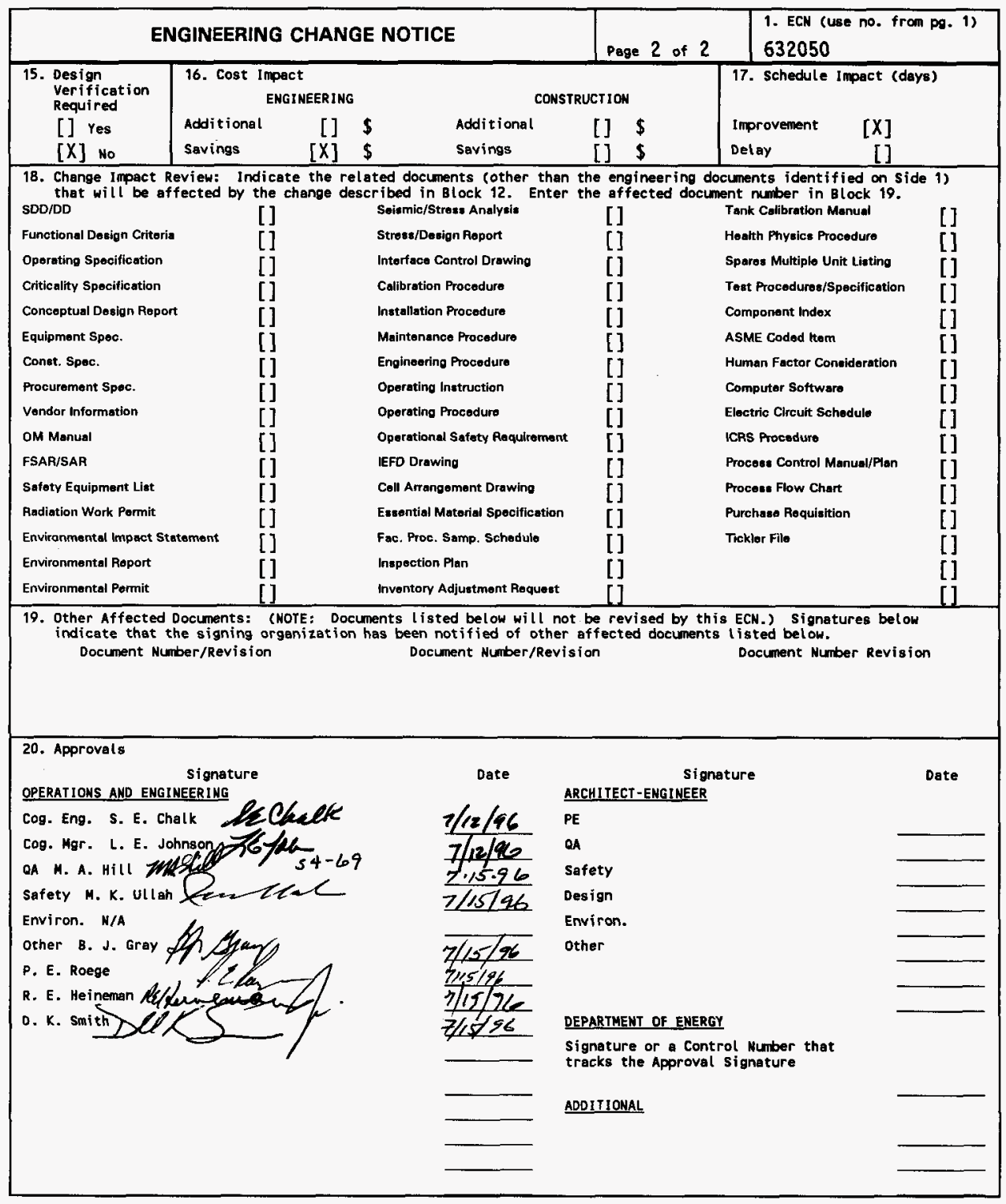




\section{B Plant Facility Description}

S. E. Chalk

Westinghouse Hanford Co., Richland, WA 99352

U.S. Department of Energy Contract DE-ACD6-87RL10930

EDT/ECN: $\begin{array}{r}632050 \\ 6302050\end{array}$

Org Code: 8M200

UC: 510

B\&R Code: EW3135090

Charge Code: KN24F

Total Pages: 89

Key Words: B Plant, facility description, spent nuclear fuels

Abstract: Buildings 225B, 272B, 282B, 282BA, and 294B were removed

from the $B$ Plant facility description. Minor corrections were made for tank sizes and hazardous and toxic inventories.

TRADEMARK DISCLAIMER. Reference herein to any specific commercial product, process, or service by trade name, trademark, manufacturer, or otherwise, does not necessarily constitute or imply its endorsement, recommendation, or favoring by the United states Government or any agency thereof or its contractors or subcontractors.

Printed in the United States of America. To obtain copies of this document, contact: WHC/BCS Document Control Services, P.O. Box 1970, Mailstop H6-08, Richland WA 99352, Phone (509) 372-2420; Fax (509) 376-4989.
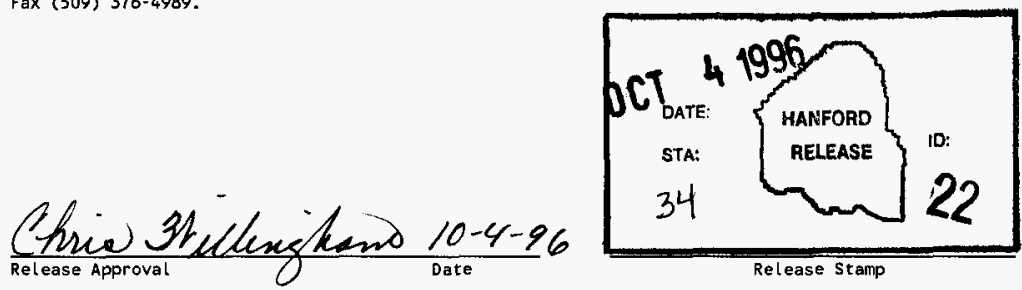

Release Stamp

\section{Approved for Public Release}




\section{RECORD OF REVISION}

(2) Title

B Plant Facility Description

CHAMGE CONTROL RECORD

\begin{tabular}{|c|c|} 
(3) Revision & (4) Description of Change - Replace, Add, and Delete Pages \\
\hline 0 & (7) Initial Release \\
\hline 1 & Rewrite of Entire Document \\
RS & \begin{tabular}{c} 
ECN- -62050 \\
\hline
\end{tabular} \\
\hline
\end{tabular}

\section{Authorized for Release}

(5) Cog. Engr. (6) Cog. Mgr. Date

L.S. Semmens J.P. Estrellado

$3 / 16 / 94$

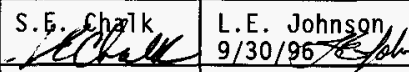


WHC-SD-WM-TM-004 REV 1

\section{B PLANT FACILITY DESCRIPTION}

WHC-SD-WM-TM-004

July 1996 
WHC-SD-WM-TM-004 REV 1

This page intentionally left blank. 
CONTENTS

1.0 FACILITY DESCRIPTION ......................... 1-1

1.1 SUMMARY DESCRIPTION . . . . . . . . . . . . . . . . . 1-1

1.1.1 Site Location and Facility Layout ........... 1-1

1.2 CONFINEMENT SYSTEMS . . . . . . . . . . . . . . . $1-2$

1.3 CONTAINMENT BARRIER . . . . . . . . . . . . . . . 1-2

1.3.1 271-B Services Building Facility Description . . . . . 1-2

1.3.2 221-B Canyon Structure Facility Description . . . . 1-3

1.3 .3 212-B Cask Station. . . . 1-7

1.4 VENTILATION SYSTEM - 221-B CANYON, 212-B CASK

STATION, AND 271-B SERVICE BUILDING . . . . . . . . 1-10

1.4.1 271-B Service Building Ventilation System . . . . . 1-10

1.4.2 Gallery Ventilation System . . . . . . . . . . . 1-10

1.4.3 Canyon Ventilation System .............1-11

1.4.4 291-B Exhaust Ventilation System .......... . 1-13

1.5 HIGH-EFFICIENCY PARTICULATE AIR FILTER SYSTEM . . . . . . $1-14$

1.5 .1 A, B, C, D, E, Cells . . . . . . 1-14

1.5.2 Water Seals on Inlet and Outlet of Filter Cells . . 1-15

1.5.3 0peration of Jets for Seals and Sumps ....... 1-16

1.5.4 Radionuclide Inventory on the Exhaust

Ventilation System .............. 1-16

1.5.5 Preventive and Mitigative Features......... . 1-17

1.6 SAND FILTER . . . . . . . . . . . . . . . . . . 1-18

1.6.1 Operation of Sand Filter.............. . . . . . . . . .

$1.7291-B$ STACK AND MONITORING SYSTEM . . . . . . . . . . . . . 1-19

1.7 .1 291-B-1 Stack . . . . . . . . . . . . . . 1-19

1.7.2 292-B Stack Monitoring Building . . . . . . . . . 1-19

1.7 .3 Sampling System ................. . . 1-20

1.7.4 Main Stack Flow Monitoring . . . . . . . . . . . 1-21

1.8 PRIMARY CONTAINMENT . . . . . . . . . . . . . . . $1-21$

1.8.1 Waste Processing Plant Equipment in Canyon Cells . . . 1-21

1.8.2 Vessel Vent Systems .............. . 1-24

1.9 LIQUID HANDLING . . . . . . . . . . . . . . . . . . . . . 1-25

1.9.1 Organic and Aqueous Storage ............. 1-25

1.9.2 Low-Level Waste System ............... . 1-25

1.9.3 211-BA Neutralization Facility.......... . 1-25

1.9.4 22l-BC Building R-13 (Change Room,

Canyon Entrance, and Dumbwaiter) .. . . . . . 1-26

1.9.5 221-BB Condensate Building (Inactive) . . . . . . 1-27

1.9.6 221-BF Effluent Control Building (Inactive) . . . . . 1-27

1.9.7 217-B Demineralizer Building (Inactive) . . . . . . . 1-27

1.9.8 276-B Building . . . . . . . . . . . . . . . . 1-27

1.9.9 Cold Chemical Storage Facilities . . . . . . . . . 1-28

1.10 UTILITIES AND FIRE PROTECTION SYSTEM . . . . . . . . . . . . . 1-29

1.10 .1 Electricity . . . . . . . . . . . . . . . . . 1-29

1.10 .2 Steam Supply System ............. 1-34

1.10 .3 Water Supply System . . . . . . . . . . . . . 1-35

1.10 .4 Deionized Water . . . . . . . . . . . . . . . . . . . 1-37

1.10 .5 Compressed Air Systems . . . . . . . . . . . . . . . . 1-37

1.10.6 Fire Protection System . . . . . . . . . . 1-39 


\section{CONTENTS (Continued)}

1.11 CANYON CRANE . . . . . . . . . . . . . . . 1-44

1.11 .1 Crane ................. . . . . . . . . . .

1.11.2 Rotary Crane Hook ............. . . . 1-44

1.11.3 Crane Optical Aids .............. . 1-44

1.11 .4 Crane Maintenance Platforms . . . . . . . . . . 1-44

1.11.5 Electrical Services ............ . 1-45

1.12 REFERENCES . . . . . . . . . . . . . . . . 1-45 


\section{LIST OF FIGURES}

1 B Plant, Waste Encapsulation and Storage

Facility, and Auxiliary Facilities ............ F-1

2 Floor Plans of the 271-B Service Building . . . . . . . . . . F-2

3 Typical Cross Section of 271-B Service Building and 221-B Canyon Structure ............... F-3

4 Cross Section of 221-B Building . . . . . . . . . . . . F-4

5 Nonprocess Cell 3, Railroad Tunnel ... . . . . . . . . F-5

6 Nonprocess Cel1 4, Waste Encapsulation and Storage Facility Solid Waste Drum Interim Storage. . . . . . . . . . F-6

7 Nonprocess Cell 40, Sample Cave . . . . . . . . . . . . F-7

8 Hot Pipe Trench Cross Sections . . . . . . . . . . . . . . F-8

9 Canyon Exhaust Ventilation Duct . . . . . . . . . . . F-9

10 212-B Cask Station ... . . . . . . . . . . . F-10

11 Ventilation Flow Pattern of the Gallery Ventilation System .... F-11

12 Electrical Gallery Supply System . . . . . . . . . . . . . F-12

13 Pipe Gallery Exhaust System Fans . . . . . . . . . . . . . F-13

14 Canyon Ventilation System . . . . . . . . . . . . F-15

15 Ventilation Diagram of the B P7 ant Processing and Service Area . . . F-17

16 The 212-B Cask Station Ventilation System . . . . . . . . F-18

17 The K2 System: 212-B Operating Gallery and Entrance Ventilation System .............. F-19

18 The K1 System: 212-B Surveillance, Cask Handling, and Cell Supply System .............. F-21

19 Typical Sand Filter Cross Section . . . . . . . . . . . F-23

20 B Plant Cell Configuration ................. . F-25

21 211-BA Neutralization Facility . . . . . . . . . . . F-27

22 Chemical Storage Area Plot Plan . . . . . . . . . . . . F-28 
WHC-SD-WM-TM-004 REV 1

\section{LIST OF TABLES}

1 Specific Buildings Within B Plant Facility . . . . . . . . . . . T-1

2 Canyon Tanks Information ................ . . . T-3

3 Chemical Storage Tanks in 211-B . . . . . . . . . . . . . . . . T-4

4 Chemical Headers to Operating Gallery Scale Tanks . . . . . . . . . . T-5

5 Aqueous Makeup Tanks. . . . . . . . . . . . . . . . . . . . T-6 


\section{LIST OF TERMS}

AMU

BCE

CAM

FPMCS

HEPA

HRHE

HVAC

LLW

MCC

$\mathrm{ms} 1$

NBS

WESF aqueous makeup unit

B Plant Chemical Sewer continuous air monitor Facility/Process Monitor and Control System high-efficiency particulate air

Hanford Regional Historical Earthquake

heating, ventilating, and air conditioning

low-level waste

motor control center

mean sea level

National Bureau of Standards

Waste Encapsulation and Storage Facility 
WHC-SD-WM-TM-004 REV 1

This page intentionally left blank. 
WHC-SD-WM-TM-004 REV 1

\section{B PLANT FACILITY DESCRIPTION}

\subsection{FACILITY DESCRIPTION}

\subsection{SUMMARY DESCRIPTION}

This chapter describes the B Plant buildings and related facilities. The design features discussed include those employed to withstand natural forces, ensure safe operation, provide personnel safety, and ensure radiological protection.

B Plant was designed to chemically process spent nuclear fuels. Radiological containment and confinement features were incorporated in the various facilities and support systems to prevent exposure of plant personnel and the general public to excessive radiation. After plant production was terminated, B Plant was thoroughly decontaminated and modified to provide for separation and purification of cesium and strontium from the fission product waste stream following plutonium and uranium recovery from irradiated reactor fuels.

The new B Plant mission consists of cleanout and stabilization of the mobile isotopes still located throughout the plant, which resulted from the separation and purification mission, while continuing operations to safely store existing radiological inventory and support Waste Encapsulation and Storage Facility (WESF) capsule storage.

\subsubsection{Site Location and Facility Layout}

The Hanford Site is located in the southeastern part of Washington state about $72-\mathrm{km}(45-\mathrm{mi})$ north of the Oregon border. The site occupies about $1,476 \mathrm{~km}^{2}\left(570 \mathrm{mi}^{2}\right)$ of arid 1 and.

In the middle of the Hanford Site, on an arid terrace about $11 \mathrm{~km}$ ( $7 \mathrm{mi}$ ) from the Columbia River, are the 200 East and 200 West Areas where fuel and waste processing and waste storage facilities are located. The locations of the 200 Areas were chosen to provide the most isolation from the Site boundaries and are the most remote from both surface and subsurface water. The groundwater table varies from $46-$ to $91-\mathrm{m}$ (150- to $300-\mathrm{ft}$ ) below the surface of the 200 Areas.

Other occupied portions of the Hanford Site include the 100 Areas along the Columbia River, where the production reactors are located; the 300 Area north of Richland, where the research and development laboratories and fuel production facilities are located; the 400 Area, or Fast Flux Test Facility site, about 11-km (7-mi) northwest of the 300 Area; and the sites of the nuclear power reactors about $3-\mathrm{km}(2-\mathrm{mi})$ north of the 400 Area.

The B Plant is a complex of several buildings and support facilities located within the northwest corner of the 2,125 acre 200 East Area (Table 1, Figure 1). The elevation is $217-\mathrm{m}(711.5-\mathrm{ft})$ above mean sea level (ms 1). It is $92-\mathrm{m}(303-\mathrm{ft})$ above the underlying water table at 124-m (408-ft) $\mathrm{msl}$, and 
77-m (253-ft) above the elevation of the Columbia River at 140-m (458-ft) ms1. The river makes its closest approach $11-\mathrm{km}(7-\mathrm{mi})$ northwest of the $B$ Plant site.

Truck transportation to and from B Plant is provided via the Hanford Site highway system, which connects the state highways at three portals on the southeast, south, and west boundaries.

The Hanford Site railroad system provides rail transport directly into the main processing (canyon) building and connects to other areas within the site. Commercial railroad connections are with Burlington Northern and Union Pacific through the south portal at North Richland.

\subsection{CONFINEMENT SYSTEMS}

This section describes the design of physical confinement barriers and their associated systems, which are referred to herein as confinement systems. The confinement systems are designed to prevent or mitigate the effects of an uncontrolled release of radioactive material, such that onsite and offsite doses and effluent concentrations are maintained within recommended guidelines during all facility operations.

B Plant is designed and operated to contain high-level contamination using multiple confinement barriers between the sources of radioactive material and the environment. The plant layout is effective in reducing casual and transient exposure to radiation fields by segregating the areas allotted to nonradiation work from the areas of high radiation. Occupational doses to workers are limited to those areas where the performance of an assigned task requires radiation exposure.

\subsection{CONTAINMENT BARRIER}

\subsubsection{1-B Services Building Facility Description}

The 271-B Building (Figure 2), consisting of a basement and three floors, is a reinforced concrete and cement block structure $49-\mathrm{m}(160-\mathrm{ft})$ long, $15-\mathrm{m}$ $(48-\mathrm{ft})$ wide, and $18-\mathrm{m}(60-\mathrm{ft})$ high. This building is attached to the north-center gallery side of the canyon.

The 271-B Building basement contains the building maintenance and instrument shops, process air compressor room, filters for the building ventilation air supply, and electrical distribution panels on the east end.

The first floor provides space for offices, locker rooms, and rest rooms. The former sodium bicarbonate and sodium bisulfate makeup tanks and receiving dock are located on the east end of the first floor.

The second floor contains administrative and supervisory offices, a lunch room, and the dispatcher's facilities. Within the dispatcher's office is an operational interface unit for the Facility/Process Monitor and Control System (FPMCS). The FPMCS provides monitoring and control interface for all 
installed and operating systems. This is accomplished by using Distributive Control System components, which are each designed to provide one of the following subfunctions:

- Input/output interface, signal conditioning, and distributive control including batch processing, alarms, and interlock logic

- Operator process monitoring and alarm handling functions

- Historical data archiving and retrieval functions

- Engineering control, logic, and interactive graphics configuration.

The third floor contains the chemical makeup head tanks, space for dry chemical storage, and the continuous deionization unit.

\subsubsection{1-B Canyon Structure Facility Description}

The waste fractionization facility, a reinforced concrete and steel structure, is divided into 20 sections with transverse section joints provided at $\approx 12-\mathrm{m}(40-\mathrm{ft})$ intervals, with the exception of sections 1,2 , and 20 . The transverse expansion joints for sections 1,2 , and 20 are spaced at $13 \mathrm{~m}$

$(44 \mathrm{ft}), 13 \mathrm{~m}(43 \mathrm{ft})$, and $14 \mathrm{~m}(44.5 \mathrm{ft})$. A1l expansion joints are keyed and offset to ensure necessary shielding requirements.

The overall length of the canyon is $247.4 \mathrm{~m}(811.5 \mathrm{ft})$, and the building is supported on a 2-m (6-ft) thick concrete slab. The canyon is 24-m (77-ft $2 \mathrm{in.})$ high with partial embedments of $7 \mathrm{~m}(22.5 \mathrm{ft})$ and $5 \mathrm{~m}(16 \mathrm{ft})$ on the south and north sides. The cross-sectional width of $20 \mathrm{~m}(66.2 \mathrm{ft})$ is constant to a height of $18 \mathrm{~m}(59.75 \mathrm{ft})$ and then increases to a maximum of $21 \mathrm{~m}(68.2 \mathrm{ft})$ at the roof top. The roof slab varies in thickness from $1 \mathrm{~m}$ (3 ft) at midspan to $1.2 \mathrm{~m}(4 \mathrm{ft})$ at the edges where it is supported by the exterior walls.

As depicted in the transverse cross section of the building (Figure 3 ), there are two interior longitudinal walls. The north exterior and interior walls support the concrete slabs for the operating, pipe, and electrical galleries. The south exterior and interior walls support the slab of the air tunnel. The cells between the two interior walls and the hot pipe trench are covered with removable concrete blocks. There is a 45-ton capacity overhead bridge crane that spans the total width of the building.

The 22l-B Building is comprised of cells, hot pipe trench, air tunnel, crane cab gallery, service area, and operating, pipe, and electrical galleries (Figure 4).

1.3.2.1 Cells. The cells provide segregation of the highly contaminated process vessels and equipment, and provide controlled access and storage space of waste and spare parts. There are 40 cells, 2 cells per section, arranged in a single row running the length of the building. These cells can be categorized as process and nonprocess cells. 
1.3.2.1.1 Process Cells. Cells 5 through 14 and 17 through 39 , except for cell 10, are standard canyon cells 5-m (17.8-ft) long, 4-m (13-ft) wide, and 6-m (22-ft) deep. Cell 10 is $15-\mathrm{m}(48-\mathrm{ft})$ deep. Each cell is separated from the adjacent cell by a $2-\mathrm{m}(7-\mathrm{ft})$ thick concrete wall. Representative standard cell sections are illustrated in Figures 5 and 6 . Approximately $19 \mathrm{~kL}(5,000 \mathrm{gal})$ of organic inventory is being stored in cells 27 and 28 , and $12 \mathrm{~kL}(3,200 \mathrm{gal})$ of aqueous inventory is stored in cells 25,26 and 30 . The low-level waste (LLW) system consists of cells $9,10,24,36$, and 39 . These cells are the only active cells in the 221-B Canyon.

1.3.2.1.2 Nonprocess Cells. Cells 1 through 4, 15, 16, and 40 are used for controlled access and storage space for radioactive solid waste and failed parts.

- Cells 1 and 2, with no partition, form a single cell 10-m (33.5-ft) wide, 11-m (35.2-ft) long, and 8-m (26-ft) deep.

- Cel1 3 (Figure 5), 5-m (16-ft) wide, 17-m (56.5-ft) 1ong, and 8-m (24.93-ft) deep, is the railroad tunnel cel1. There is a $5-m$ by $7-m$ (16-ft by 24-ft) motor-operated rolling steel door at the end of a 53-m (174-ft) railroad tunnel attached to the north end of the cell. The cell has a steel sliding cover instead of a cell block. The railroad tunnel is used routinely in the transfer of packaged containers from 221-B to a railroad cask car for movement to the burial area. The tunnel is used also during nonroutine transfer of process equipment to and from the 221-B Canyon.

- Cel1 4 (Figure 6 ) is used for interim storage of contaminated solid waste generated in 225-B. The 208-L (55-gal) standard drums containing contaminated waste are placed in casks and transported to the 221-B tunnel on a truck. The cask is lifted from the truck by the overhead canyon crane and placed on the deck. The drums are set on removable racks made with grating floors. A maximum of 295 drums can be stored in the cell.

- Cell 40 (Figure 7) provided a shielded sample cave (no longer in service) for obtaining high-activity level samples from the cells 38 (inactive) and 39 process vessels. Personnel access from 225-B to the cell 40 sample cave is provided by a $1-m(3.5-f t)$ wide by $2-m$ $(7.2 \mathrm{ft})$ high by $2-\mathrm{m}(7-\mathrm{ft})$ deep passageway located at the southwest corner of cell 40 .

The cell 40 cover blocks have been replaced with $1-\mathrm{cm}(0.25-i n$. thick steel plate. Flooring is provided at an elevation of about $5 \mathrm{~m}(17 \mathrm{ft})$ above the original concrete floor of the cell and consists of $1-\mathrm{cm}(0.37-\mathrm{in}$.$) thick nonskid steel plate over 4-\mathrm{cm}$ (1.5-in.) steel grating. Elevation of the flooring results in an overall height from floor to ceiling of $3.3 \mathrm{~m}$ (10 ft $9 \mathrm{in}$.). The sample cave is located in the extreme southeast corner of cell 40. The sample cave is constructed of reinforced, high-density concrete with $0.5-\mathrm{m}(1.5-\mathrm{ft})$ thick walls and a $6-\mathrm{cm}(2.30-\mathrm{in}$.$) thick floor.$ The cave is provided with a single cover block of $1-\mathrm{m}(2.23-\mathrm{ft})$ thick reinforced concrete. Overall inside dimensions of the sample cave are $2 \mathrm{~m}(5.5 \mathrm{ft})$ by $1.2 \mathrm{~m}(4.5 \mathrm{ft})$ by $2 \mathrm{~m}(6.25 \mathrm{ft})$ from the 
floor to bottom of the cover block. The inner walls of the cave are lined with Type 304 stainless steel. The cave floor is sloped to a center 5-cm (2-in.) drain. The north wall of the cave contains a lead-glass viewing window that is $1-\mathrm{m}(\approx 4-\mathrm{ft})$ wide by $1-\mathrm{m}(3-\mathrm{ft})$ high. Sampling operations were performed in the sample cave with the aid of a master-slave mechanical manipulator.

1.3.2.1.3 Service Pipe Lines. Original pipe lines servicing the cells are buried in concrete and terminate in a row of connector nozzles on the cell wall $3-m(9-f t)$ below the canyon deck level. Equipment is placed on the cell floor and held in position by guides built into the cell, which establishes a standard relationship between the wall connector nozzles and the vessels. This arrangement makes possible the prefabrication of replacement vessels, jumpers, and other equipment for any given location in the cell.

Additional nozzles were added later at various elevations, originating from either the hot pipe trench or the pipe gallery. These nozzles allow additional routes to be established between cells.

1.3.2.1.4 Cell Cover Block. Cover blocks form the movable confinement barrier to the cells and the hot pipe trench. During normal operation of the plant, the 2-m (6-ft) thick concrete cell cover blocks serve as shielding barriers from high-intensity radiation emanating from the process equipment and allow ventilation air into the cells, which prevents the escape of airborne radioactive contamination from the cells to the canyon deck. These blocks are constructed of a proper size and uniformity so that the gap on the stepped interlocking edges, horizontal or vertical, cannot exceed 3-cm (1-in.) maximum nor be less than $0.3-\mathrm{cm}\left(0.13-\mathrm{in}_{\text {. }}\right)$ minimum when the blocks are placed in any possible position. This clearance provides ease of insertion and removal of cell blocks during maintenance and removal of equipment.

Cells 5, 20, and 23 have cover blocks, which are 1-m (3-ft) thick to allow adequate clearance for the in-cell equipment. These blocks are structurally equivalent to the other blocks and are painted red along the borders for easy identification.

1.3.2.2 Hot Pipe Trench. The hot pipe trench, parallel to the process cells from cell 5 through cell 40, provides the isolation and shielding of contaminated piping for intercell solution transfer and vessel venting systems. The trench is $2-\mathrm{m}(8-\mathrm{ft})$ wide and $3-\mathrm{m}(10.5-\mathrm{ft})$ deep and $216-\mathrm{m}$ $(708-f t)$ long (measured from the canyon deck). The trench is accessible for remote maintenance after the removal of the $137-\mathrm{cm}$ (54-in.) thick concrete cover blocks (Figure 8 ).

Lead brick shielding barriers exist in the hot pipe trench between cel1s 12 and 13. Piping stubs extend through the barrier to permit future tie-ins.

Lines from the process cells pass through concrete walls and terminate in connector nozzles in the hot pipe trench. Routing changes in the hot pipe trench are possible by installing prefabricated jumpers to the nozzles with connector heads. 
1.3.2.3 Cell Drain Header. The cell drain header, a 61-cm (24-in.) inside diameter, vitreous-clay pipe embedded in a minimum of $0.3 \mathrm{~m}(\mathrm{l} \mathrm{ft}$ ) of concrete below and on either side, is a route for the collection of solutions from the canyon deck, cell flushes, and leaks from process systems in cells and the pipe trench. The cell drain header starts $10-\mathrm{m}(33-\mathrm{ft})$ below the deck at each end of the canyon. It has a gradient of $1 \%$ and drains into Tank $10-1$. The $15-\mathrm{cm}$ (6-in.) diameter vertical pipes drain any solution from the process cells or pipe trench.

1.3.2.4 Canyon Crane Cabway and crane. The canyon provides space for the crane cabway, a flow path for the supply air and a containment volume for the confinement of airborne radioactive contamination from the cells (Figure 4).

The crane cabway is located on the north side of the building above the operating gallery. The cabway is separated from the canyon by a $1.5-\mathrm{m}$ (5-ft) thick and $3-\mathrm{m}(9.3-\mathrm{ft})$ high concrete parapet wal1. The parapet wail provides shielding from direct gamma radiation for the operators in the cab. The steel structure of the cab provides protection from scattered radiation. Entry to the cab is through a 8-cm (3-in.) thick doorway, and high-efficiency particulate air (HEPA) filtered ventilation air is provided through a shielded duct from a blower mounted on the top. Emergency exits are provided at each stairwell along the north side of the building and are about $24.4 \mathrm{~m}(80 \mathrm{ft})$ apart. Al1 applicable safety standards are met.

1.3.2.5 Galleries. Parallel to the process cells on the north side are the electrical, pipe, and operating galleries. The galleries are 4-m (14-ft) wide tunnels that extend the length of the building from cell 4 to cell 40 , except for the operating gallery, which extends the length of the canyon. The galleries are shielded by the 3-m (9-ft) thick (at the cell level) and 2-m (7-ft) thick (above the canyon deck level) north interior longitudinal wall (Figure 4).

1.3.2.6 Air Tunnel and Exhaust Ventilation Duct. The air tunnel, located within the confines of the 22l-B Building, and the exhaust ventilation duct, 4-m (14.4-ft) below the deck level and below grade, form the last containment for the release of potentially contaminated air. The air passes through HEPA filters before final dispersal from an elevated stack.

1.3.2.6.1 Air Tunnel. Located below the hot pipe trench, the air tunnel is the exhaust manifold for air from the process ce11s, the hot pipe trench, and the 212-B Cask Station. The cross-sectional area of the air tunnel is a square measuring $3 \mathrm{~m}$ by $3 \mathrm{~m}(10.5 \mathrm{ft}$ by $10.5 \mathrm{ft})$. The air tunnel runs parallel to cells 5 through 40 and is interconnected to the cells by twelve 36-cm (14-in.) diameter cylindrical holes through a 2-m (7-ft) thick partition wal1. Six of the holes are located at elevation $-7 \mathrm{~m}(-22.10 \mathrm{ft}$ ) (relative to canyon deck) and the other six holes are located at elevation $-6.5 \mathrm{~m}(-21.3$ $\mathrm{ft}$.) except for cell 15, where the two sets of six holes are located at elevations $-36 \mathrm{~cm}(-14.11 \mathrm{in.})$ and $-5 \mathrm{~m}(-16.6 \mathrm{ft})$. Ce11s 10 and 40 are connected to the air tunnel through a single $36-\mathrm{cm}$ (14-in.) diameter hole.

Cells 1 through 4 are not connected to the canyon air tunnel but are connected to the exhaust ventilation duct by a $25-\mathrm{cm}(10-$ in.) pipe outside the canyon, which enters the duct $5.5-\mathrm{m}(\approx 18-\mathrm{ft})$ below the deck leve 1 and $25 \mathrm{~cm}$ (10 in.) away from the wall. There are three exhaust ports, one each for 
cells 3 and 4 and one for cells 1 and 2 . These ports are all located 2-m $(5.5-\mathrm{ft})$ below deck level. The ports for cells 3 and 4 are located $5 \mathrm{~m}$ $(15 \mathrm{ft})$ and $3 \mathrm{~m}(10.2 \mathrm{ft})$ from the west end of section 2 . The port for cells 1 and 2 is located $2 \mathrm{~m}(7 \mathrm{ft})$ from the west end of section 1 .

1.3.2.6.2 Exhaust Ventilation Duct. The exhaust ventilation duct, along with the filters, forms the final barrier to potentially contaminated air reaching the environment through the stack (Figure 9).

The main exhaust duct, 59-m (194.5-ft) long, extends perpendicular to the side of the 221-B Canyon Building. The main exhaust duct splits into the filter exhaust duct at $38-\mathrm{m}(123.5-\mathrm{ft})$ south of the canyon and runs parallel to the main duct. The main exhaust and the filter exhaust duct merge into a variable cross-section duct that forms the plenum for the inlet to the exhaust fans. The adjoining plenum of the main exhaust duct is sealed off by two concrete walls. It has three $2-m(6-f t)$ long and $1-m(4.3-f t)$ wide openings at the top for the stainless steel exhaust ducts, with automatic adjustable dampers for the two electric and one turbine driven fan. The accident analyses found that an operable backup steam turbine is not required.

The $1-\mathrm{m}$ by $1-\mathrm{m}(4-\mathrm{ft}$ by $3-\mathrm{ft})$ stainless steel outlet ducts are connected to a reinforced concrete duct by $43^{\circ}$ inclined entry ports. Extending from the exhaust end of this duct is a $4-\mathrm{m}(13-\mathrm{ft})$ long stainless steel duct. The stainless steel duct breeches the stack and the acid-brick lining for the passage of the gases for dispersal through the stack.

\subsubsection{2-B Cask Station}

The 212-B Cask Station is situated at the southwest corner of B Plant so that process and utility piping and other supporting services in B P1ant could be conveniently used. The 212-B Cask Station and 221-B (B Plant) cel1 35 contained facilities for loading and unloading fission products from the shielded transfer casks. These transfers are no longer performed at B P1ant and the 212-B facility is considered inactive (Grady and Kirkman 1971).

1.3.3.1 212-B Cask Station Facility Description. The 212-B Cask Station facilities include a truck lock, a cask handling and surveillance room (canyon), an underground operating gallery and cell, and attached laundry storage, and change rooms (Figure 10). The 212-B Cask Station Building is a sheet-metal covered, steel-frame structure, 23-m (76-ft) long by 15-m (48.7-ft) wide. The inside height of the building varies from $7-\mathrm{m}(22-\mathrm{ft})$, in the cask handling and surveillance room, to $11-m(35-f t)$ in the cell area. There are two personnel access door on the east side of the building, and an emergency exit door on the west side of the building. Truck access to the building is provided through a 4-m (14-ft) high by $4-m(14-\mathrm{ft})$ wide rolling steel door located on the east side of the building.

1.3.3.1.1 Truck Lock. The truck lock is located at the south end of the building and is $6-\mathrm{m}(21-\mathrm{ft})$ wide by $14-\mathrm{m}(45-\mathrm{ft})$ long by $8-\mathrm{m}(26-\mathrm{ft}) \mathrm{high}$. A 30 -ton crane is located on an overhead rail system $5-\mathrm{m}(16.5-\mathrm{ft})$ above the floor. The wall between the truck lock and the cask storage and surveillance room is 23-cm (9-in.) thick concrete and contains two doorways. One doorway is located near the west end and is for personnel access between the two 
rooms. The second doorway is located on the north wall, approximately in the middle of the truck lock, and was used for passage of the cask and crane between rooms. This doorway contains a double door, $3-\mathrm{m}(10-\mathrm{ft})$ wide and 3.4-m (11-ft) high, for cask passage, plus a third door located across the top of the wall for crane passage between rooms. The craneway door is hinged at the top and swings northward and up towards the ceiling of the cask handling and surveillance room. This door is $7-\mathrm{m}(24-\mathrm{ft})$ wide and $2-\mathrm{m}(8-\mathrm{ft}) \mathrm{high}$. A third doorway is located in the northeast sector of the truck lock for passage between the truck lock and the dirty laundry storage room.

1.3.3.1.2 Cask Storage and Surveillance Room. The dimensions of the cask storage and surveillance room are $16.5-\mathrm{m}(54-\mathrm{ft})$ 1ong by $15-\mathrm{m}(48.7-\mathrm{ft}$ ) wide by $7-\mathrm{m}(22-\mathrm{ft})$ high. The 30 -ton crane runs on an overhead rail system $4-\mathrm{m}(12.6-\mathrm{ft})$ above the floor. Located at the north end of the room is the 4-m by $4-\mathrm{m}(12.5-\mathrm{ft}$ by $12.5-\mathrm{ft})$ by $1-\mathrm{m}(2-\mathrm{ft})$ thick cover block for the cell. Adjacent to the southwest corner of this cover block is a $1-\mathrm{m}$ by $1-\mathrm{m}$ (3.75-ft by $3.75-\mathrm{ft}$ ) access hatch, which permits personnel entry to the cell through a labyrinth passageway.

1.3.3.1.3 212-B Cell. The 212-B cell is located underground near the north end of the building and is $3-\mathrm{m}(11-\mathrm{ft})$ square by $5-\mathrm{m}(17-\mathrm{ft})$ deep. The south wall of the cell is $1.2-\mathrm{m}(4-\mathrm{ft})$ thick concrete containing a $1.2-\mathrm{m}$ (4-ft) square, 102-cm (40-in.) deep, lead-glass viewing window equivalent shielding to $38-\mathrm{cm}$ (15-in.) of lead and passageways for two manipulators. The north and east walls and the cell floor are $0.3-\mathrm{m}(1-\mathrm{ft})$ thick concrete, while the west wall is $1-\mathrm{m}(2-\mathrm{ft})$ thick concrete. The walls and bottom of the cell are 1 ined with 16 gauge, Type 304 stainless steel. Along the west, south, and east walls of the cell, a $1-\mathrm{m}(3-\mathrm{ft})$ high steel grating platform extends around a 2-m (7-ft) diameter hole provided for casks. The personnel entrance labyrinth is separated from the cell by $1-\mathrm{m}(2-\mathrm{ft})$ of concrete and has a $4-\mathrm{cm}$ (1.75-in.) thick door that opens onto the grating platform. The cell north wall contains filters and an exhaust air duct to the existing 221-B ventilation air tunnel. An 20-cm (8-in.) square, and $18-\mathrm{cm}$ (7-in.) deep sump is located in the cell's northeast corner. Four $1-\mathrm{cm}(0.5-\mathrm{in}$.) stainless steel chemical spray nozzles are located around the top and the middle of the cel1. An intercom system provides communication between the cell and the operating gallery.

1.3.3.1.4 Operating Gallery or Control Room. The operating gallery is located directly south of the cell and is 8-m (27-ft) long, 4-m to 6-m (12-ft to $18-\mathrm{ft})$ wide, and $3-\mathrm{m}(11-\mathrm{ft})$ high. The room contains the viewing window, manipulator controls, an instrument panel, a motor control center (MCC), a heating, ventilating, and air conditioning (HVAC) panel, and a sump. The only personnel access to the room is from a door on the east wall. All of the walls of the room are $0.3-\mathrm{m}$ (1-ft) thick concrete, except opposite the cell where the wall is $1-m(4-\mathrm{ft})$ thick. The ceiling is 41-cm (16-in.) thick concrete, and the floor is $15-\mathrm{cm}$ (6-in.) thick.

1.3.3.1.5 Change Room. The change room is located north of the main entrance door on the east side of the building. The room is $5-\mathrm{m}$ to $6-\mathrm{m}$ (18-ft to 20-ft) long, 6-m (19-ft) wide, and 4-m (12-ft) high. It contains clothing storage bins, lockers, a sink, a toilet, a shower, a drinking fountain, and a hot water heater. The room has two personnel access doors, one on the south side and the other near the northeast corner. 
1.3.3.1.6 Laundry Storage Rooms. The clean and dirty laundry for 212-B is stored in two small rooms south of the main entrance door on the east side of the building. Each of these rooms, 3-m (10-ft) square and $4-m(13-\mathrm{ft})$ high, is entered through a $1-m(3-f t)$ wide sliding steel door.

1.3.3.2 Process Equipment and Piping. The cask station process equipment and piping includes the cell piping, the pipe encasements, the aqueous makeup unit (AMU) facilities, and the underground waste tank (TK-CS-3).

1.3.3.2.1 Cell Piping. All service and utility piping enter the cell through the cell west wall. All process piping enters the cell through the cell east wall. The process 1 ines extend through the wall and are joined in a series of flushing manifolds, which are installed in a $10-\mathrm{cm}(4-\mathrm{in}$.$) deep,$ water-filled tray designed to hold any line leakage and to provide some process line shielding.

1.3.3.2.2 Pipe Encasements. The 212-B Building has three separate buried pipe encasements that connect the 212-B Cask Station with the 221-B Building. One encasement contains the hot process lines while the other two encasements contain service lines.

The hot pipe encasement begins at the east edge of the cell wall and enters the 221-B Building at cel1 35. The entire length of the encasement and the lines it contains have a uniform slope toward the 221-B Building of $0.6 \mathrm{~cm} / \mathrm{m}(0.24 \mathrm{in} . / \mathrm{ft})$. The encasement is constructed of $15-\mathrm{cm}$ (6-in.) thick concrete on the sides and top and $31-\mathrm{cm}$ to $20-\mathrm{cm}$ (12-in. to 8-in.) thick concrete on the bottom. The top and sides of the encasement are covered with a membrane water proofing. The top of the encasement has been covered with an additional $46 \mathrm{~cm}$ (18 in.) of concrete to provide shielding, and below the change room, the encasement is covered by an additional $61 \mathrm{~cm}$ (24 in.) of concrete. The encasement contains a branch $7 \mathrm{~m}(24 \mathrm{ft})$ from the east wa11 of 212-B that contains two spare lines originally intended for future rail services.

The east service line encasement begins at the northeast edge of the cell wall and enters the 221-B Building between cells 37 and 38 . The encasement consists of a 25-cm (10-in.) earthenware pipe that has a constant slope towards the $221-\mathrm{B}$ Building of $0.5 \mathrm{~cm} / \mathrm{m}(0.20 \mathrm{in} . / \mathrm{ft})$. After entering 221-B, the pipe becomes level and continues to the electrical gallery.

The north service line encasement begins at the north wall and enters 212-B Building between cells 39 and 40. The encasement consists of a $25-\mathrm{cm}$ (10-in.) earthenware pipe and a $15.2-\mathrm{cm}(6-\mathrm{in}$.$) Schedule 5$ pipe that has a constant slope towards the $221-B$ Building of $0.5 \mathrm{~cm} / \mathrm{m}(0.20 \mathrm{in.} / \mathrm{ft})$. The $15-\mathrm{cm}$ (6-in.) pipe is inserted partly through the side of the $25-\mathrm{cm}(10-\mathrm{in}$. pipe and parallel to it. After entering 221-B, the pipes become level and continues to the electrical gallery. 


\subsection{VENTILATION SYSTEM - 221-B CANYON, 212-B CASK STATION, AND 271-B SERVICE BUILDING}

The ventilation system, in association with physical containment, makes up the confinement system. The two essential features of the ventilation system are the pressure differentials and the HEPA filtration. A system of pressure differentials is used to prevent the flow of air from areas of high contamination to areas of low contamination.

There are three independent ventilation systems for the 221-B Canyon and the 271-B Service Building. The vessel ventilation systems form a part of the primary containment feature discussed in Section 1.8.2. The 212-B Cask Station has an independent supply system, but interfaces with the canyon exhaust ventilation system by exhausting into the air tunnel.

\subsubsection{1-B Service Building Ventilation System}

Fresh air is drawn from the outside through $5-\mathrm{m}$ by $5-\mathrm{m}$ (16-ft by $16-\mathrm{ft}$ ) vertical, rectangular cross-section ducts reaching to the roof of the building into a central air filtering, washing, and conditioning unit. The air is fed through the ducts to the four floors of the building by a fan with a counterclockwise rotation. The fan delivers $2,265.4 \mathrm{~m}^{3} / \mathrm{min}\left(80,000 \mathrm{ft}^{3} / \mathrm{min}\right)$ at $8-\mathrm{cm}(3-\mathrm{in}$.$) water static pressure and 21.1{ }^{\circ} \mathrm{C}\left(70^{\circ} \mathrm{F}\right)$. The static pressure is maintained slightly above that in the operating gallery, such that air flows from 271-B into the galleries. Air is exhausted from the building through exhaust fans on several of the floors.

\subsubsection{Gallery Ventilation System}

Twelve supply fans and seven exhaust fans provide ventilation for the galleries in the 221-B Building (Figure 11). Ten fans, rated at $142 \mathrm{~m}^{3} / \mathrm{min}$ $\left(5,000 \mathrm{ft}^{3} / \mathrm{min}\right)$, supply the operating gallery, and two $283-\mathrm{m}^{3} / \mathrm{min}$ $\left(10,000-\mathrm{ft}^{3} / \mathrm{min}\right)$ fans supply air to the electrical gallery (Figure 12). Six fans exhaust air from the pipe gallery, and one exhausts air from the electrical gallery. Four of the exhaust fans draw $226 \mathrm{~m}^{3} / \mathrm{min}\left(8,000 \mathrm{ft}^{3} / \mathrm{min}\right)$ each, while the other three are rated at $453 \mathrm{~m}^{\frac{3}{3}} / \mathrm{min}\left(16,000 \mathrm{ft}^{3} / \mathrm{min}\right)$.

Fresh air is introduced into the operating and electrical galleries. The air flows through transfer grills in the floors of the operating and pipe galleries, where it is exhausted to the outside. The airflow pattern differs for the eastern end of the building, where both the pipe and electrical galleries are detached by the railroad tunnel. In this section, air supplied to the operating gallery, flows down to the pipe gallery, and then to the electrical gallery for exhaust.

For contamination control purposes, the galleries are maintained at a pressure slightly higher than that of the canyon, but lower than atmospheric pressure and the occupied 271-B Building. Exhaust air passes through HEPA filters upstream of the exhaust fans. 
Air supply units are equipped with steam heating coils and evaporative cooling units. The supply and exhaust fans may be stopped by controls in the dispatcher's office.

1.4.2.1 Operating Gallery Supply Fans. The ten gallery supply fans are located in each stairwell on the second floor of 221-B (one per stairwel1). Each unit is controlled on the FPMCS (Figure 11).

1.4.2.2 Gallery Exhaust Fans EF-1 through EF-7. There are seven outside mounted exhaust fans of which six fans, EF-2 through EF-7, serve the pipe gallery and one of the fans, EF-1, serves the electrical gallery in the first section of the building (Figure 13).

These fans can be turned on or off with the FPMCS. When the fans are operating, gallery exhaust air is drawn through prefilter and HEPA fiTter banks and then discharged to the atmosphere through the fan outlet.

The air flow rate of each fan is controlled manually by adjusting the vaned inlet damper of the fan to maintain a positive static pressure in the pipe gallery, with respect to the 221-B Canyon and negative with respect to atmospheric pressure and the 271-B building.

\subsubsection{Canyon Ventilation System}

The canyon ventilation system capabilities are based on the reliability of the supply and exhaust ventilation fans to maintain a continuous controlled airflow pattern, which utilizes a system of pressure differentials to govern the flow of aerosols and/or radioactive particulates that can escape the structural containment barriers of the canyon (Figure 14). Performance parameters of the ventilation system include the following:

- Maximum air flow rate through the canyon of $2,122 \mathrm{~m}^{3} / \mathrm{min}$ $\left(75,000 \mathrm{ft}^{3} / \mathrm{min}\right)$

- Maintenance of sufficient airflow through the cells to maintain the cell temperature below $51.7^{\circ} \mathrm{C}\left(125^{\circ} \mathrm{F}\right)$ for the protection of electrical and instrument systems and to minimize thermal gradients between the canyon and cell air

- Provision of sufficient openings and restrictions to provide an air flow rate of $1,062 \mathrm{~m}^{3} / \mathrm{min}\left(37,500 \mathrm{ft}^{3} / \mathrm{min}\right)[48.8 \mathrm{~m} / \mathrm{min}(160 \mathrm{ft} / \mathrm{min})]$ through an open cell.

1.4.3.1 Canyon Airflow. Differential pressures direct airflow from areas of low radiological contamination to areas of higher radiological contamination. The exhaust fans produce a vacuum that draws air from the canyon into the cells. The 22l-B Canyon is at a negative pressure, with respect to the galleries, and the galleries are at a negative pressure relative to atmospheric pressure and the 271-B support building (Figure 15).

Air is drawn in from the environment by the supply units. Air enters the canyon along the crane cabway and flows over the parapet wall and down onto the canyon deck. Air is pulled into the cells through gaps in the cover 
blocks, then it is drawn through openings into the exhaust air duct (wind tunnel). The air passes through HEPA filters and is monitored for radionuclides during release out of the stack.

The vessel vent 1 system (Section 1.8.2) was designed to vent and filter the gases from those process vessels that did not contain significant quantities of ammonia compounds. The vessel vent 2 system was designed to vent, scrub, and filter gases from process vessels in which ammonia was present.

1.4.3.2 Canyon Supply Fans. There are 10 canyon supply fans, one for each section, rated at $142 \mathrm{~m}^{3} / \mathrm{min}\left(5,000 \mathrm{ft}^{3} / \mathrm{min}\right)$ and $6-\mathrm{cm}(2.35-\mathrm{in}$.) static pressure. These supply fans, along with the canyon exhaust fans, establish airflow patterns for contamination control. During normal operation, flow rate is maintained by the operation of 4 to 5 supply fans. Supply fans 1,5 , 9,13 , and 17 automatically shut off if the canyon-to-atmosphere differential pressure drops below $0.2 \mathrm{~cm}$ wg (0.1 in. $\mathrm{wg})$, and supply fans $3,7,11,15$, and 19 will shut off if canyon-to-atmosphere differential pressure drops below $0.4 \mathrm{~cm}$ wg $(0.17 \mathrm{in}$. wg). Canyon supply fans can be started and stopped through manual on/off switches on the FPMCS. If canyon differential pressure is lost, the canyon supply fans will shut off automatically.

The incoming air temperature is maintained in the comfort zone for personnel working in the canyon by steam heating or evaporative cooling, depending upon the environmental air temperature. The incoming air is filtered to remove dust and particulates (Buckingham 1967 and RHO 1969).

1.4.3.3 212-B Cask Station Ventilation Supply Fans. There are two independent ventilation supply fans that service the contingent and the radiation zones. The two supply systems are located in the HVAC equipment room of the 212-B Building (Figure 16).

The ventilation systems are designed to prevent or limit the spread of contamination from the process cell to the operating areas or the surrounding atmosphere. The cell is maintained at a negative pressure, with respect to the operating areas, which are negative with respect to the atmosphere. Air is introduced into the cask station by the supply fans and is exhausted from the cell through a duct filter to the B Plant air tunnel.

1.4.3.3.1 K2 System (Operating Gallery). This ventilation system supplies air to the operating gallery and the entrance and exhausts to the atmosphere. The $\mathrm{K} 2-4-2$ air handling unit includes a $71-\mathrm{m}^{3} / \mathrm{min}^{2}\left(2,500-\mathrm{ft}^{3} / \mathrm{min}\right)$ supply fan and an evaporative cooling unit. The cabinet heaters located inside the main door and the control room are rated for $7 \frac{\mathrm{min}}{3}\left(250 \mathrm{ft}^{3} / \mathrm{min}\right)$ and $16 \mathrm{~m}^{3} / \mathrm{min}\left(575 \mathrm{ft}^{3} / \mathrm{min}\right)$ and are manually controlled. The operating gallery and the entrance form the contingent zone, which is maintained at a pressure slightly above atmospheric so that leakage flow is maintained in the direction of the radiation zone (Figure 17).

1.4.3.3.2 KI System (Surveillance, Cask Handling and Cell Supply). This system services the surveillance and the cask handling room and the cell. Atmospheric air is supplied by fans $\mathrm{Kl}-5-1$ and $\mathrm{K} 1-5-2$, located in the HVAC room on the west side of the building. Air flows through the surveillance, 
then the cask handling areas to the north end of the building, where it is drawn into the cell. From the cell, the air passes through a filter into the 221-B Building exhaust air duct.

Either one or both fans operate, depending upon the season. Both fans provide steam heat during the winter and fan K1-5-1 provides evaporative cooling during the summer. The supply air flow rate is manually controlled via a radial damper on the inlet to fan $\mathrm{Kl-5-1}$ (Figure 18).

\subsubsection{1-B Exhaust Ventilation System}

There are two electric motor driven fans used during normal operation and a steam turbine driven fan is on automatic standby. They are ducted for parallel operation (GBC 1966 and CFC 1963).

1.4.4.1 Electric Motor Driven Fans. Two centrifugal fans, each capable of delivering $1,062 \mathrm{~m}^{3} / \mathrm{min}\left(37,500 \mathrm{ft}^{3} / \mathrm{min}\right)$ are used in the exhaust ventilation system. The maximum operating temperature of the fans is $52^{\circ} \mathrm{C}\left(125^{\circ} \mathrm{F}\right)$. The fans are directly driven by 460-V, 150-hp motors.

Each fan is provided with an inlet and outlet seal damper requiring a minimum of $448 \mathrm{kPa}\left(65 \mathrm{lbf} / \mathrm{in}^{2}\right)$ instrument air to open. These fans also have pneumatic radial throttling or modulating dampers to adjust the exhaust flow. These dampers are controlled by the FPMCS in response to the canyon-toatmosphere differential pressure transmitter in the automatic operation mode. As an alternative, the damper position (\% closed) can be selected manually on FPMCS. The fan controls are located in the 291-B turbine house and the C8-577 substation, with the exception of the damper controls, which can be operated remotely from the FPMCS.

1.4.4.2 Steam Turbine Driven Fan. The steam turbine fan (not required to be operable) is the backup fan maintained on automatic standby. This unit consists of an exhaust fan with a steam turbine drive complete with control equipment.

The exhaust fan has a capacity of $1,062 \mathrm{~m}^{3} / \mathrm{min}\left(37,500 \mathrm{std} \mathrm{ft}^{3} / \mathrm{min}\right)$. The steam turbine is designed to operate on $1,551-\mathrm{kPa}\left(225-1 \mathrm{bf} / \mathrm{in}^{2}\right.$ gauge) saturated steam exhausting at $35-\mathrm{kPa}\left(5-1 \mathrm{bf} / \mathrm{in}^{2}\right.$ gauge) back pressure. The turbine has an overspeed trip mechanism to protect it from damage caused by high rotational speed. The turbine is set in the auto mode for automatic operation. In the event of an overspeed trip, the overspeed mechanism on the turbine must be manually reset for the turbine to operate normally. A signal is sent to the FPMCS when the overspeed switch is tripped.

1.4.4.3 Canyon Ventilation Instrumentation and Control system. This section discusses the instrumentation and control that maintains the canyon air pressure at a vacuum for contamination control through ventilation.

1.4.4.3.1 Canyon to Atmosphere Differential Pressure. This canyon pressure is the control point used to maintain a system of pressure differential to direct the contaminated air through the 291-B filter to the atmosphere. To ensure this, the canyon-to-atmosphere pressure is currently maintained at a negative pressure of $1 \mathrm{~cm}(0.3 \mathrm{in.})$ of water. 
1.4.4.3.2 Turbine Overspeed Trip Mechanism. The steam turbine is equipped with an over speed trip mechanism to protect the turbine from operating at unsafe speeds. In the event that the turbine speed governor fails or the speed of the turbine increases above safe operation, a valve will be tripped open diverting the steam supply from the turbine.

1.4.4.3.3 Differential Pressure Across the Electric Fans. The differential pressure across each electric fan is used as a control point to verify that the fan is operating correctly. A pressure alarm switch for each fan will trip if the pressure across the fan drops below $1 \mathrm{~cm} w g(0.3 \mathrm{in}$. wg) automatically shutting down the electric fans and starting the steam turbine.

1.4.4.3.4 Instrument Air Pressure. Instrument air is used in the 291-B canyon exhaust ventilation system for a variety of pneumatic instruments.

1.4.4.3.5 Exhaust Air Temperature. Each filter is equipped with thermocouples located at the inlet and between each filter bank. In addition, there are thermocouples located near the filter ducts and two installed in the wind tunnel access hole near the R-3 canyon entrance.

There are temperature recorders for $D$ and $E$ filters in the filter instrument building, 291-BF and 291-BG. A, B, and C filter temperatures and the wind tunnel temperatures are recorded on the FPMCS. A temperature rise in any of the locations will cause an alarm on the FPMCS. An unusually high temperature on these thermocouples could be an indication of a fire in the duct or the filters. A temperature rise probably is the most reliable warning of a fire before an actual filter breach.

1.4.4.3.6 Relative Humidity. The air passing the filters is monitored by a dew point probe located in the wind tunnel upstream of the exhaust HEPA filters. The percentage relative humidity is read on the FPMCS.

\subsection{HIGH-EFFICIENCY PARTICULATE AIR FILTER SYSTEM}

\subsubsection{A, B, C, D, E, Cells}

Ventilation air from the 221-B Canyon, vessel vent 1 , and 212-B Cask Station is exhausted through the B Plant operating HEPA filter cell before being discharged to the atmosphere. The 224-B building is also connected to the B Plant exhaust duct and passively vented through the HEPA filters. The sand filter, built in 1948, is the emergency backup filter to the operating HEPA filter. A, B, and $C$ filters are retired and no longer used in the exhaust ventilation system.

The D filter cell (in use) and E filter cell (ready to be made operable) each have a design capacity of $2,124 \mathrm{~m}^{3} / \mathrm{min}\left(75,000 \mathrm{ft}^{3} / \mathrm{min}\right)$ of air and are constructed in parallel with the A, B, and C filter cells. The cell structure is a reinforced concrete building with steel filter frames inside. The concrete and steel exposed to the exhaust air stream are painted with corrosion resistant paint. 
The $D$ and $E$ filter cells are equipped with two banks of $85 \%$ National Bureau of Standards (NBS) prefilters and three banks of HEPA filters. The two prefilter banks and the first HEPA filter bank are designed to allow the upper one quarter of the filter bank to be lowered. The remaining three quarters of the filter banks remains fixed. This feature permits bypassing of a filter bank or banks should excess pressure drop occur as a result of filter loading. The final two HEPA banks are permanently mounted. At this time, both prefilters and the first HEPA filter bank in the $D$ filter have been bypassed.

A stainless steel $4-\mathrm{m}$ by $4-\mathrm{m}$ (12-ft by $12-\mathrm{ft})$ mesh screen is installed $1-\mathrm{m}(\approx 4 \mathrm{ft})$ upstream of the first prefilter bank. Each prefilter and HEPA filter unit is equipped with a stainless steel $\approx 1.2 \mathrm{~m}(\approx 4 \mathrm{ft})$ mesh screen downstream of each unit.

Each individual prefilter (bag type) of both the prefilter banks is equipped with sheet metal separators coated with (Fecht et al. 1974) intumescent paint to retard propagation of any potential filter fire to other filters in the same bank. The intumescent paint absorbs heat by forming air bubbles, thus providing an insulating barrier on the surfaces of the metal separators and insulating one filter from the next (Rourke 1973 and Cast7e 1973).

Temperature elements are installed in the D filter inlet air stream, between each bank of filters, and in the outlet air stream. Temperatures can be recorded in the filter instrument building 291-BF, with a high temperature alarm located on the FPMCS. Liquid level indicating instruments housed in the 291-BF Building are provided for the filter sumps, and the filter outlet seal with a high-level sump and seal alarm located on the FPMCS. Differential pressures across individual filter banks can be recorded in the 291-BF Building with a preset high alarm on the FPMCS.

The seal water is supplied from a heat-traced insulated storage tank with a 14-kL (3,700-gal) capacity. The filter seal can be filled from the sand filter seal tanks and/or the storage tank.

\subsubsection{Water Seals on Inlet and Outlet of Filter Cells}

The $B$ and $C$ filters are the only filters with inlet seals, but every filter has an outlet seal. The inlet seals provided isolation during construction of the future filter cells. D filter uses a concrete plug to provide isolation from $E$ filter. The outlet seals prevent airflow through the retired filters. Because D filter cell is in service, all other outlet seals are full.

The water for filling the inlet and outlet seals on the filter cells is supplied to concrete valve pits. In each pit there is a valve on the water supply line and a valve to the respective seal fill line. A rubber hose line with quick disconnect fittings is provided for connecting the supply to the fill line. The rubber hose line is always disconnected when not in use to prevent inadvertent addition to the wrong seal or flooding through a leaking valve. The valves in the fill line are locked in the closed position. 
The inlet and outlet seal pits also contain the steam supply and discharge lines for the seal removal jets. Control valves for the steam to the jets are located outside the pits with a combination blank and orifice plate installed on the upstream end of the valve, which is normally blanked when the jet is not is use. The discharge 1 ine from each jet has a downstream ball valve, which is locked out when not in use.

\subsubsection{Operation of Jets for Seals and Sumps}

Jet controls are located in a concrete pit identified as a filter sump and instrument pit with valves for manually controlling the steam jet, which is located inside the pit and is blanked when not in use. The discharge line from each jet has a check valve, which also is kept blanked when not in use. The intermediate sump jet on the number one system has been used more frequently; therefore, instead of installing blanks, the steam valve to the jet and the ball valve in the discharge line are kept closed and locked when the jet is not in use.

There are 284-L/min (75-gal/min) jets located at 291-B for the filter inlet and outlet seals and the sumps. The discharge from all the jets drains through a common header system to the 221-B wind tunnel via the access hole near the R-3 canyon entrance and finally to tank TK-10-1. Because of the limited drain capacity, one jet is operated at a time. The depth in the sumps is $41 \mathrm{~cm}$ ( $\approx 16$ in.), and liquid levels are measured by gauges located in the instrument house.

\subsubsection{Radionuclide Inventory on the Exhaust Ventilation System}

In December 1992, water accidently overflowed into the A filter housing to a depth of $86 \mathrm{~cm}$ (34 in.) above the floor (Gehrke 1992, 1993). As a result, the first row and $1 / 8$ of the second row of HEPA filters was wetted. This accident yielded the best sample of filter inventory to date.

$\begin{array}{cccc}\text { Cel1 } & { }^{90} \underline{\mathrm{Sr}(C i)} & { }^{137} \underline{\underline{C s}(\mathrm{Ci})} & \text { Total }(\mathrm{Ci}) \\ \mathrm{A} & 12,000 & 18,000 & 30,000 \\ \text { B } & 29,000 & 43,000 & 72,000 \\ \text { C } & 16,000 & 25,000 & 41,000 \\ \text { D } & 50,000 & 550,000 & 600,000 \\ \text { Total } & 107,000 & 636,000 & 743,000\end{array}$

The water removed $2,500 \mathrm{Ci}$ of ${ }^{137} \mathrm{Cs}$ and $180 \mathrm{Ci}$ of ${ }^{90} \mathrm{Sr}$. Based on past process history, the cesium on the filters was judged to be $100 \%$ soluble. The strontium compounds could have been relatively insoluble; therefore, the strontium was conservatively estimated to be $10 \%$ soluble. The water samples 
indicated an isotopic split of $60 \%$ cesium and $40 \%$ strontium. The other filters were assumed to have similar isotopic splits, and the A filter results were used to revise previous estimates on the $B$ and $C$ filters.

There has not been a large number of radionuclides other than ${ }^{137} \mathrm{Cs}$ and ${ }^{90} \mathrm{Sr}$ in B Plant since 1968 and the material in the plant had considerable aging before being processed. This would indicate that the filters should not contain significant inventories of radionuclides other than ${ }^{137} \mathrm{Cs}$ and ${ }^{90} \mathrm{Sr}$. The samples taken of the water in the A filter support this conclusion and report the only substantial inventory on the filters to be ${ }^{137} \mathrm{Cs}$ and ${ }^{90} \mathrm{Sr}$.

Available literature indicates that the organic materials of construction for HEPA filters, such as plywood frames, rubber base adhesives, and rubber gaskets, begin to lose mechanical strength after a total absorbed radiation dose of $5 \times 10^{8}$ to $10^{9}$ rads. Because of the high levels of radiation exposure over a period of 20 to 25 years, A, B, and C filters are at risk of failure. For this reason, $A, B$, and $C$ filters will not be placed in service or be used as backup fi1ters.

\subsubsection{Preventive and Mitigative Features}

1.5.5.1 Cel1 Fire Detection System. Stored organic liquids are a possible source of fire. Process cells that contain or could contain organic liquids are equipped with dual fire detectors and a foam, fire-retardant spray system. Activation of one of the two fire detectors will alert operations and the Hanford Fire Department. Activation of both detectors in a cell will initiate operation of the foam, fire-retardant system to that cell. Cell sprays can be activated manually to extinguish the fire.

1.5.5.2 Ignition Source. Sources of ignition in the canyon and filter cells are minimized.

1.5.5.3 Housekeeping Practices. Good housekeeping practices are emphasized in the canyon area to prevent the collection of combustible debris on the deck, in the cells, or in the exhaust air ducts.

1.5.5.4 Airflow Diversion System. The 29l-B exhaust filtration facilities include installed capability for diverting the exhaust airflow from the HEPA filter to the sand filter, dual heat detectors in the exhaust air duct before and after the HEPA filter system, and a $19-\mathrm{L} / \mathrm{min}$ (5 gal $/ \mathrm{min}$ ) and a $189-\mathrm{L} / \mathrm{min}$ (50-gal/min) water spray system in the exhaust air duct upstream of the filter system. The $19-\mathrm{L} / \mathrm{min}(5-\mathrm{gal} / \mathrm{min})$ water spray will be activated by either the exhaust air duct heat detectors or the organic cell fire protection system. The $189-\mathrm{L} / \mathrm{min}(50-\mathrm{gal} / \mathrm{min})$ exhaust duct spray is actuated manually.

\subsubsection{E and D Filter Cells.}

1.5.5.5.1 Design Features. Screens are provided upstream of the first prefilter and immediately following each bank of prefilters and HEPA filters.

1.5.5.5.2 Isolation of Individual Deep Bed-Bag Type Filters. Each bag type filter unit in the two prefilter banks is isolated by metal separators coated with intumescent paint. 
1.5.5.5.3 Spacing Compartmentalization and Sections. The spacing between the second prefilter bank and the first HEPA filter bank is $1.5 \mathrm{~m}$ $(\approx 5 \mathrm{ft})$, an increase of $0.6 \mathrm{~m}(2 \mathrm{ft})$ over comparable spacing in $\mathrm{C}$ filter. The filters are divided into three sections and compartmentalized in each cell (Fecht et al. 1973, 1975).

\subsection{SAND FILTER}

In the event that the HEPA filter system becomes inoperable, the 291-B sand filter can be manually activated as a backup by draining and filling appropriate water seals. The accident analyses do not require an operable backup sand filter.

The sand filter is located $52-\mathrm{m}(171-\mathrm{ft})$ south and $19-\mathrm{m}(62-\mathrm{ft})$ west of the east end of the canyon building. The filter is connected by $1.5-\mathrm{m}$ ( $5-\mathrm{ft}$ ) wide and $2-\mathrm{m}(6-\mathrm{ft})$ deep stainless steel ducts $5.5-\mathrm{m}(\approx 18-\mathrm{ft})$ long and above grade. The fi1ter, 34-m (110-ft) long, 17-m (55-ft) wide, and $6.4-\mathrm{m}(21-\mathrm{ft})$ high, except at the west end where it is $8-\mathrm{m}(\approx 26.5-\mathrm{ft})$ high, is a reinforced concrete structure with a floor slab 30.5-cm (12-in.) thick at an elevation of $1.2-\mathrm{m}(4-\mathrm{ft})$ below grade. The roof consists of 60 precast concrete slabs, 18-cm (7-in.) thick, 5-m (16.8-ft) long, and $1.5-\mathrm{m}(4.92-\mathrm{ft})$ wide, covered by waterproofing membrane composed of layers of asphalt and fabric. The roof is supported by $30.5-\mathrm{cm}(12-\mathrm{in}$.$) thick concrete walls and by 30.5-\mathrm{cm}$ by $46-\mathrm{cm}$ (12-in. by 18-in.) precast concrete beams upheld by two rows of $31-\mathrm{cm}$ by $31-\mathrm{cm}$ (12.24-in. by 12.24-in.) reinforced concrete columns spaced $3 \mathrm{~m}(10 \mathrm{ft})$ apart. Figure 19 shows a cross-section of the sand filter. The floor has $20-\mathrm{cm}$ by $30.5-\mathrm{cm}$ by $41-\mathrm{cm}$ (7.76-in. by $12-$ in. by $16-\mathrm{in.})$ hollow concrete blocks laid longitudinally and separated by $0.1-\mathrm{cm}(0.04-\mathrm{in}$.$) wood dowels for distributing$ the incoming air.

The sand filter is a deep bed of rock, gravel, and sand constructed in layers graded with about 2 to 1 variation in granule size from 1 ayer to 1 ayer. The collection mechanism of a sand filter is largely gravity settling and Brownian diffusion. Airflow direction is upward, and granules decrease in size in the direction of the airflow. A top layer of moderately coarse sand is added to prevent fluidization of the finer sand. The superficial velocity is around $1.5 \mathrm{~m} / \mathrm{min}(5 \mathrm{ft} / \mathrm{min}$ ), and the pressure drop across the contiguous layers of sand sized from grade I to grade VII (with type C 2-Bays at duct end only) is $18 \mathrm{~cm}(7.1 \mathrm{~cm})$ at a volumetric air flow rate of $708 \mathrm{~m}^{3} / \mathrm{min}$ $\left(25,000 \mathrm{ft}^{3} / \mathrm{min}\right)$.

The sand filter has a greater mass than the other filter types and sand is inert to most gases and only gravity is required to ensure that bypassing does not occur (Burchsted, Kahn, and Fuller 1976). The maximum flow rate is $736 \mathrm{~m}^{3}\left(26,000 \mathrm{ft}^{3} / \mathrm{min}\right)$ and the normal operating flow rate is between $510 \mathrm{~m}^{3}$ and $651 \mathrm{~m}^{3}\left(18,000\right.$ and $\left.23,000 \mathrm{ft}^{3} / \mathrm{min}\right)$.

Smoke cannot be removed practically from the exhaust gases, and the capacity of the filter to accept smoke can become an important consideration. Sand filters are nearly invulnerable to the heat of fire. 


\subsubsection{Operation of Sand Filter}

Upon disruption of the operating filters, the sand filter can be activated. The airflow through the sand filter should be limited to $736 \mathrm{~m}^{3} / \mathrm{min}\left(26,000 \mathrm{ft}^{3} / \mathrm{min}\right)$ to prevent fluidization of the filter bed. The sand filter is either activated or taken out of service by the use of a water seal in the outlet duct and a motorized butterfly valve in the inlet duct.

The sampling and detection instrumentation for the 291-B stack monitoring equipment is given close attention by constant monitoring of the equipment in the 292-B Building during the initial stages of the sand filter operation.

1.6.1.1 Filling Sand Filter Seal. The seal is filled through manually operated valves. There are two ways to drain the water seal; switch to the sand filter from the HEPA filter system and drain the water to the D filter outlet seal, or drain the water to the wind tunnel and tank TK-10-1.

\subsection{1-B STACK AND MONITORING SYSTEM}

\subsubsection{1-8-1 Stack}

The 291-B-1 Stack, located 65-m (214-ft) south and 27-m (87-ft) west of the east end of the canyon, provides the elevated release path for the dispersion of potentially contaminated canyon air. The $61-\mathrm{m}(200-\mathrm{ft})$ stack column, constructed of reinforced concrete and vertical steel reinforcements, is a circular tapering hollow shaft. At the base, the shaft has a 4-m (14-ft) outside diameter and is $0.3-\mathrm{m}(1-\mathrm{ft})$ thick. At the top, the shaft has a $2-\mathrm{m}$ $(7.5-\mathrm{ft})$ outside diameter and is $0.2-\mathrm{m}(0.5-\mathrm{ft})$ thick. The top of the stack column is covered with an alloy cap (Fecht et al. 1973).

Within the stack is an acid-proof brick lining laid in acid-proof mortar completely separated from the column by a free, unobstructed annular space. The lining is a self-supporting, free-standing structure of varying wall sections and thicknesses at various elevations, and tapers from a $2-m$ (7-ft) inside dimension to a $1.5-\mathrm{m}(5-\mathrm{ft})$ inside dimension $15-\mathrm{cm}(6-\mathrm{in}$.) above the top of the concrete column. The acid-proof brick lining, reinforced with alloy metal bands, is provided with an alloy cap anchored to the bricks by means of bolts.

The stack has a catch tank located at the base that receives condensate from the stack. The catch-tank solution can be jet transferred to the air tunnel that drains to tank TK-10-1 in 221-B.

\subsubsection{2-B Stack Monitoring Building}

The 292-B Stack Monitoring Building is a concrete block structure containing the sampling and monitoring equipment for continuously measuring the gaseous and particulate emissions from the 291-B-1 Stack. The building has one level on grade with a poured concrete floor covering an area of $31 \mathrm{~m}^{2}$ $\left(336 \mathrm{ft}^{2}\right)$. The exterior and the interior walls are concrete blocks and the concrete deck roof is covered with tar and gravel. 
Instrument controls, alarms, and indicators are located within this structure except for the high airborne-radiation beacon and system-failure be11, which are mounted on the exterior of the 292-B Building. Redundant remote alarms and indicators are continuously monitored by the FPMCS in the 271-B Building dispatcher's office.

\subsubsection{Sampling System}

The stack sampling system includes probes located in the stack, a record sampler, a backup-record sampler, and a beta/gamma monitor.

The near isokinetic sample probes are located $\approx 15 \mathrm{~m}(50 \mathrm{ft})$ from the base of the stack. Two separate near isokinetic air extraction probes are installed to withdraw representative air samples from the main stack airstream. One of the probes is for the record sampler, and the second probe is for the backup-record sampler and the beta/gamma continuous air monitor (CAM).

The record-sampling system operates continuously unless the airflow drops below $425 \mathrm{~m}^{3} / \mathrm{min}\left(15,000 \mathrm{ft}^{3} / \mathrm{min}\right)$. The CAM system operates for a 11 airflows. The generic system has a switch receptacle linked to the exhaust fan operation. A flow switch disrupts power to the receptacle when stack airflow stops and restores the power upon detection of flow resumption. Sample probes are designed for isokinetic sample extraction based on the average stack velocity. The average value is determined from velocity profile measurements taken at or near the plane of sample extraction.

Two 2-cm (0.75-in.) sample-transport lines and two $1-\mathrm{cm}(0.5-i n$.$) pitot$ tube assemblies extend from the probe-mounting assembly to the monitoring instruments in the 292-B Building. The sample-transport lines are heat traced and insulated to inhibit condensation. Three separate vacuum pumps draw air through the sample-transport lines for the record sampler, the backup record sampler, and the beta/gamma monitor.

1.7.3.1 Record Sampler. One probe is dedicated to extract an air sample that passes through a paper record filter at a minimum flow rate of $0.1 \mathrm{~m}^{3} / \mathrm{min}^{-}$ $\left(2.2 \mathrm{ft}^{3} / \mathrm{min}\right)$. A flow rate exceeding $0.11 \mathrm{~m}^{3} / \mathrm{min}\left(4.0 \mathrm{ft}^{3} / \mathrm{min}\right)$ will damage the record filter and, therefore, cannot be exceeded. Airflow rates through the record filter are sensed, regulated, indicated, and totalized in the 292-B Instrument Building. A low sample air flow rate activates a local alarm and a remote alarm. The local alarm, connected to a beacon outside the 292-B Building, indicates low flow, and the remote alarm in the 271-B Building dispatcher's office indicates a monitor failure.

1.7.3.2 Beta/Gamma Sampler. Another probe draws a sample through a flow splitter. One side of the flow splitter is ported to the CAM. The other side of the flow splitter is ported to a backup record filter. The flow rate to both is $0.01 \mathrm{~m}^{3} / \mathrm{min}\left(2 \mathrm{ft}^{3} / \mathrm{min}\right)$.

The CAM monitors the particulate-matter buildup on filter paper for the detection and measurement of beta/gamma radiation. In the event of radiation buildup exceeding established parameters, a local high beta-radiation alarm is activated, as well as a remote stack radiation alarm on the FPMCS. 
1.7.3.3 Backup-Record Sampler. The second side of the flow splitter is ported to a backup-record sampler that collects the effluent particulates on filter paper. The airflow through the backup record filter is regulated and equipped with a local flow rate indicator. In the event of low flow in the backup-sampler line, a local alarm and a remote alarm are activated.

\subsubsection{Main Stack Flow Monitoring}

Three separate locations are available for obtaining f]ow rate measurements for the 291-B-1 Stack. The first location is in the duct immediately downstream of the exhaust fans and consists of eight separate ports. The second location is through pitot tubes mounted in the air duct at the base of the stack. The third location for velocity measurements is through two pitot tubes (static and total pressure) installed in the stack at an elevation of $15 \mathrm{~m}(50 \mathrm{ft})$ from the base of the stack.

\subsection{PRIMARY CONTAINMENT}

The tanks and equipment located in the B Plant canyon are in a single array of cells which are sunk below deck level. Each cell is covered by four $1.8-\mathrm{m}$ (6-ft) thick concrete blocks. Figure 20 depicts the B Plant cell configuration. Cells $9,10,22,24$, and 39 are being used during transfers of liquid LLW to Tank Farms. Ce11s 25, 26, 27, 28, and 30 are being used to store spent organic solvent and aqueous inventory.

Radioactive solutions during intersectional transport are transferred by way of the pipe trench running the length of the canyon to the boundary of cell 4. The pipe trench is covered by stepped $1.4-\mathrm{m}(4.5-\mathrm{ft})$ thick concrete covers similar to those used for the process cells.

The process equipment, tanks, and piping provide physical barriers and form the primary confinement of the radiochemical solutions in the process. The vessels and equipment are compartmentalized within the cells, and the intersectional piping for transport of radiochemical solutions is located within the hot pipe trench area to isolate high risk zones and minimize the potential hazardous effects of design-basis accidents.

The piping from the galleries is used for nonradioactive chemical transfer through seal pots to the equipment and the tanks. The valves at the wall serve as an isolation device. The cold-chemical and the utility pipes are curved where they pass through the walls to provide radiation shielding. Seal pots and valves located near the north wall piping penetration are designed to minimize transport of radioactive materials into operating areas and provide the demarcation boundary for contamination control between the accessible cold-chemical lines and the isolated radioactive areas.

\subsubsection{Waste Processing Plant Equipment in Canyon Ce1ls}

This section covers the major equipment used in the diversified process at B Plant (Buckingham 1967). Details concerning B Plant equipment are available in the B Plant Equipment and Facilities Information Manual (RHO 1969). 
1.8.1.1 Canyon Tanks. The tanks in the canyon are cylindrical or oval enclosed cross-section tanks, except for the open topped $38-k L(10,000-g a l)$ waste collection tank in cell 10. Table 2 provides pertinent data and information applicable to active canyon tanks, and Figure 20 indicates the cell allocation to all canyon tanks. All tanks were equipped with cooling coils except for pump tank TK-29-4, which is located within makeup tank TK-29-2. Cooling coils are no longer required. Some of the valves on the system leak through, which causes a flow that must be increased by keeping two coils active in order to monitor before release.

1.8.1.2 Concentrators and Condensers. The four concentrators in B PIant are designated as follows:

- E-5-2 Strontium product concentrator

- E-20-2 Cesium product concentrator

- E-23-3 Low-level waste concentrator

- E-38-6 Purified cesium concentrator.

Al1 these concentrators have been inactivated.

1.8.1.3 Centrifuge. Cel1s 12,13 , and 32 each have a centrifuge and a supernatant receiver. These centrifuges are inactivate.

1.8.1.4 Ion Exchange Column. The ion-exchange columns were used in the cesium purification process but are now inactive. One ion-exchange column is located in cell 18 and the other in cell 38. The T-18-2 ion exchange column, a Class 1 vessel $2-m(6-f t)$ diameter and $5-m(15-f t)$ high, still contains Duolite ${ }^{1}$ ES-286 resin. The T-38-5 ion exchange column, a vessel $31-\mathrm{cm}$ (12.20-in.) diameter and $4-m(13.78-f t)$ high, is filled with a synthetic zeolite ion-exchange medium.

TK-2-1 in cell 2 stores $\approx 4 \mathrm{~m}^{3}\left(130 \mathrm{ft}^{3}\right)$ of Duolite ARC-9359 resin previously used in the T-18-2 ion exchange column.

1.8.1.5 Solvent Extraction. The B Plant solvent extraction battery was used to recover strontium and rare earths from current acid waste and acid sludge and to purify strontium. There are four pulse columns designated as follows:
- $T-30-1$
$1 A$ - Extraction
- $\mathrm{T}-28-1$
1B - Strontium strip
- $T-27-1$
IC - Rare earth strip
- $T-29-1$
1S - Scrub.

These columns are no longer used in B Plant. Tanks in cel1s 26, 27, 28, and 30 store organic and aqueous solutions resulting from the solvent extraction process. The organic consists of normal paraffin hydrocarbons, tributyl phosphate, and di-2-ethylhexyl phosphoric acid.

1.8.1.6 Pumps. Pumps located within the process tanks are supported and fixed on the top of the vessel by means of a mounting flange resting on a nozzle flange. A vertical column, containing the pump stages as an integral

${ }^{1}$ Duolite is a trademark of the Diamond Shamrock Chemical Company. 
part, extends downward to the desired distance. The number of stages is determined by the desired head and capacity of the pump. Solutions enter the pump axially at the lower end of the column and pass vertically upward through contiguous stages in the column. The pumped solution is discharged radially through a side arm at the top of the column section just above the mounting flange. The drive shaft extends concentrically through the column and is guided by sleeve bearings lubricated by the pumped solution. The drive shaft is directly coupled to the shaft of the electric pump motor mounted above the mounting flange. The weight of the shaft and the thrust developed during operation are absorbed by the motor bearings. A throttle bushing is provided at the point where the drive shaft emerges from the column section. Leakage past the throttle bushing is returned to the vessel.

Portable pumps are also used in the canyon since many of the existing pumps are inoperable. These pumps may be used for organic solvent/aqueous transfers or LLW transfers.

1.8.1.7 Pump Agitators. In several B Plant tanks, 1imited space has necessitated modifying existing pumps into pump agitators. The modification consists of drilling three holes in the bowl of the bottom pump stage. A portion of the solution entering the first stage is forced through the holes back into the tank, and a portion passes on to the upper pump stages. Through the use of a diaphragm-operated valve on the pump discharge line, a pump agitator may be used for two modes of operation: with the pump discharge valve closed, the solution will recirculate back to the tank agitating the contents of the tank and with the pump discharge valve open, the solution will be pumped and agitated simultaneously. Pump agitators cannot be used for batch contractors because they cannot pump without also agitating the solution.

1.8.1.8 Agitators. A1l agitators in the plant are of stainless steel construction. The agitator shaft is connected through a flexible coupling to the output shaft of a speed reducer that is directly connected to the shaft of an electric motor. The agitator shaft is fabricated in two sections; the upper portion carries both thrust and radial bearing loads, while the lower portion carries the agitator blades. The two sections are joined together with a rigid, flange-type coupling. The upper section is sealed by a kerosene-lubricated seal at the upper end of a cylindrical torque tube welded in the mounting flange. The torque tube also contains a grease-lubricated guide bearing near its lower end to provide shaft support near the point of load application. Contact of process solutions with the guide bearing is prevented by means of positive air pressure introduced to the torque tube. Kerosene drippings from the seal and air escape through the clearance between the agitator shaft and the lower end of the torque tube.

1.8.1.9 Transfer Jets. Transfer jets are used for transferring various solutions. The rated water siphoning capacity ranges from 11 to $284 \mathrm{~L} / \mathrm{min}$ ( 3 to $75 \mathrm{gal} / \mathrm{min}$ ) with somewhat smaller jets used in samplers. Solutions transferred by steam jet are diluted $\approx 5 \%$. Although steam is usually used for the motive fluid, both water and air may be used. Solutions at temperatures greater than about $63{ }^{\circ} \mathrm{C}\left(145^{\circ} \mathrm{F}\right)$ cannot be jetted because suction of the solution is great enough to cause the solution to vaporize. However, submerged jets are capable of jetting solutions up to about $79^{\circ} \mathrm{C}\left(175^{\circ} \mathrm{F}\right)$. 
1.8.1.10 Gang Valves. Gang valves are used to operate the steam jets in B Plant. A gang valve consists of four spring-closed, globe-type valves with all working parts constructed of bronze. The four valves control steam, air, shutoff, and vent. The proper use of the gang valves prevents back flow of radioactive solutions into the partial vacuum created by condensation of steam in unpurged lines. The four positions of a gang valve are presented below.

Position Gallery Jet Air Steam Operation

$\begin{array}{lllll}1 & 0 & C & C & C \\ 2 & C & 0 & 0 & C \\ 3 & C & 0 & C & 0 \\ 4 & 0 & 0 & C & C\end{array}$

Normal closed position

Air purge of jet or sparger

Steam supplied to jet or sparger

Maintenance position - jet vented to

$C=$ closed $0=$ open

operating gallery.

\subsubsection{Vessel Vent Systems}

The primary function of the vessel vent system was to maintain the atmosphere of the canyon vessels, which contain solutions of fission products of concentrations greater than $26 \mathrm{Ci} / \mathrm{L}(100 \mathrm{Ci} / \mathrm{gal})$ or solutions with temperatures greater than $70^{\circ} \mathrm{C}\left(158^{\circ} \mathrm{F}\right)$ at a vacuum with reference to the cell containing the vessel (Buckingham 1967). B Plant no longer stores these types of solutions therefore the vessel vent system is no longer required.

Dilution air is provided to active tanks with the potential for generating an explosive hydrogen atmosphere. The tanks are then vented to prevent pressurization and contamination spread to the galleries. If an alternate method of venting dilution air and hydrogen is not provided (i.e., open tank nozzles), the vessel vent system could be used.

There were two separate vent systems, and the equipment for both systems is located in cell 22 .

- Vessel vent No. 1. This system was designed to vent and filter the gases from those process vessels, which do not contain ammonia.

- Vessel vent No. 2. This system was designed to vent, scrub, and filter gases from process vessels in which ammonia is present. Some vessels vented to the main vent header 146 via two other headers, $69 \mathrm{~A}$ and $69 \mathrm{~B}$, while others vented directly to header 146 .

The vessel vent 2 system has been shut down because ammonia is no longer used in B P1 ant. The vessel vent 2 header, 146, has been connected with the vessel vent 1 header, 22, via a direct jumper installation in cell 34 and by eliminating various liquid seals throughout the plant. The vessel vent 2 equipment remains in place. 


\subsection{LIQUID HANDLING}

\subsubsection{Organic and Aqueous Storage}

B P1ant stores $\approx 19 \mathrm{~kL}(5,000 \mathrm{gal})$ of contaminated organics and $12 \mathrm{~kL}$ $(3,200 \mathrm{gal})$ of contaminated aqueous resulting from the solvent extraction process. The organic and aqueous phases have been separated and are stored in four canyon tanks. The organic is stored in TK-27-3 and TK-28-3, and the aqueous is stored in TK-26-1 and TK-30-3. A caustic wash is used to remove radionuclides from the organic phase to allow for better sampling, characterization, and disposition. 0ther tanks which may also be used during the caustic wash include TK-25-2, TK-26-3, and TK-27-2.

\subsubsection{Low-Leve1 Waste System}

Currently cells $9,10,24$, and 39 are part of the B Plant low-level liquid waste system. Liquid from the operating gallery floor drains, scale tank drains, scale tank overflows in the operating gallery, and floor drains in the pipe gallery are collected in a $15-\mathrm{cm}$ (6-in.) stainless steel header that traverses the length of the electrical gallery. This flow normally exits the header into TK-900A or TK-900B where a sample is pulled and both the pH and radiological content are tested. If the sample is within guidelines for release, the liquid is sent to the chemical process sewer through the Neutralization Facility (211-BA), where the $\mathrm{pH}$ is further adjusted if needed, before being sent to B-Pond.

If the sample is out of specification, the waste is sent to the LLW cells in the 221-B canyon. This waste along with the additional LLW generated (i.e, decontamination of equipment at WESF, 291-B water seals, miscellaneous leaks) is transferred to Tank Farms via an underground $8-\mathrm{cm}$ (3-in.) line. Sodium hydroxide and/or sodium nitrite is added to the LLW before transfer to protect the underground storage tanks. A sample is also taken before transfer to characterize the waste.

\subsubsection{1-BA Neutralization Facility}

The 211-BA Neutralization Facility provides neutralization capabilities for the B Plant Chemical Sewer (BCE) (Swanson 1989). The facility minimizes the potential for release of corrosive liquids that exceed regulatory limits to the environment by neutralizing corrosive liquids. The system consists of a pump station (211BA-151), which intercepts the BCE flow downstream of access hole 14 and pumps the BCE effluent to the 211-BA, Facility where the stream flows into four parallel neutralization units. Neutralization of the stream is accomplished by the injection of sulfuric acid or sodium hydroxide from separate $757-\mathrm{L}(200-\mathrm{gal})$ double-wall tanks within the facility. 
The pump station is a $15,009-\mathrm{L}(3,965-$ gal) sump with two variable speed pumps, rated at $757 \mathrm{~L} / \mathrm{min}(200 \mathrm{gal} / \mathrm{min})$. The sump pumps run separately or together and feed the neutralization system under normal operating conditions at $568 \mathrm{~L} / \mathrm{min}(\approx 150 \mathrm{gal} / \mathrm{min})$. The liquid level in the sump is normally maintained at $60 \%$ capacity $(102 \mathrm{~cm}$ [40 in.]). The sump has a gravity overflow that will bypass the neutralization facility.

A schematic of the neutralization system is given in Figure 21 .

Flow from the pump station enters the neutralization system where it is divided into the four neutralization units. Each neutralization unit consists of three chambers in series that contain probes, agitators, and injectors. If the $\mathrm{pH}$ is found to be outside the range of 6 to 9 , the neutralization process will begin automatically by injecting sodium hydroxide or sulfuric acid to adjust the effluent $\mathrm{pH}$. Each neutralization unit has a continuous flow rate of $189 \mathrm{~L} / \mathrm{min}(50 \mathrm{gal} / \mathrm{min})$ and can manage a peak flow rate of $303 \mathrm{~L} / \mathrm{min}$ $(80 \mathrm{gal} / \mathrm{min})$. The final $\mathrm{pH}$ value of effluent discharged from the neutralization system to the BCE will be within a pH of 4 to 10 . If the effluent $\mathrm{pH}$ is found to be outside the acceptable limits, flow will be diverted back to the pump station for automatic recycle through the neutralization system.

The effluent from the neutralization system flows by gravity into the 211-BA Building sump, and during normal operating conditions (i.e., pH within limits), the liquid then gravity flows from the sump into the $B C E$ and combines with the B Plant cooling water system, which discharges to B-Pond.

Instrumentation in 211-BA measures liquid in the sulfuric acid and sodium hydroxide tanks, BCE flow rate through the neutralization facility, liquid height in the 211-BA-151 pump pit sump, and $\mathrm{pH}$ of the BCE effluent in the neutralization units and the building sump. Beta and gamma radiation in the BCE is monitored by an offline sample monitoring system. Sample lines are routed from the 211-BA to the monitoring system and are then discharged to the 21l-BA sump. Instruments also are installed to monitor and detect leaks in the neutralization units and the sulfuric acid and sodium hydroxide storage tanks and detect loss of power. Signals from the instrumentation are fed into the B Plant facility distributive control system to remotely control and monitor the neutralization system by operations. Monitored operating parameters are relayed to the B Plant dispatchers and displayed on an operator interface unit located in the dispatcher's office.

\subsubsection{1-BC Building R-13 (Change Room, Canyon Entrance, and Dumbwaiter)}

The building is a single-story change room built on a $9-\mathrm{m}$ by $8-\mathrm{m}(30.5-\mathrm{ft}$ by 24.8-ft.) concrete $s] a b$ and attached to the south end of section 7 of the 221-B Building. The walls are constructed of standard concrete blocks reinforced with steel bars, and the core is filled with concrete. The roof is a built-up metal deck. The 22l-BC K1 ventilation system is described in Figure 23 and Table 4 . 
1.9.4.1 Dumbwaiter. The primary function of the R-13 dumbwatter is to transport sampling equipment in and out of the canyon to eliminate the hazards of manually carrying this material up and down the stairs.

\subsubsection{1-BB Condensate Building (Inactive)}

The 22l-BB Condensate Building is located immediately south of the 221-B Building and directly above a vault that provides housing for two 2-kL (400-gal) steam condensate and process condensate tanks. Instruments for sampling and monitoring the steam condensate and process condensate stream are located in the condensate building. B Plant is no longer generating this effluent stream and this building is not used.

Air from the vault containing the steam (BCS) and process (BCP) condensate tanks is exhausted via the 221-BB Building through a single-stage HEPA filter, exhauster, and stack.

\subsubsection{1-BF Effluent Control Building (Inactive)}

The 221-BF Effluent Control Building provides interim storage of process condensate in two 49-kL (13,000-gal) tanks located below grade for sampling before disposal to the cribs. B Plant is no longer generating this effluent stream and this building is not used.

A negative atmosphere to 221-BF Building pressure differential is maintained by the exhaust fans. Approximately $16 \mathrm{~m}^{3} / \mathrm{min}\left(560 \mathrm{ft}^{3} / \mathrm{min}\right)$ of ambient air flows across a heating coil, through a $36 \%$ NBS filter and backdraft dampers, and into the sample and monitor rooms. The air from the monitor room, sampler boxes, batch tanks, and the effluent control pit flows through a common exhaust duct with a heating coil, two HEPA filters, and opposed blade manual dampers. A pressure differential (sample room to effluent control) allows a flow of 7 to $13 \mathrm{~m}^{3} / \mathrm{min}\left(260\right.$ to $\left.450 \mathrm{ft}^{3} / \mathrm{min}\right)$ across a HEPA filter. The exhaust flow is recorded and effluents are sampled before being released to the atmosphere.

\subsubsection{7-B Demineralizer Building (Inactive)}

The demineralizer building is located in the 211-B Chemical Storage Area. This process has been replaced by a continuous deionization system, which is located on the third floor of 271-B.

\subsubsection{6-B Building}

This building, attached to sections 4 and 5 on the north side of the 221-B Building was used previously for organic make-up and storage. This building has been inactive since B Plant shut down solvent extraction, and currently this building is used for paint storage. 


\subsubsection{Cold Chemical Storage Facilities}

This section provides a description of the facilities needed for nonradioactive chemical receiving, storage, and transfer to the in-canyon cell equipment (Figure 22). These solutions are termed cold chemicals because they do not present radiological hazards. These chemicals may pose a toxicological and/or carcinogenic hazard.

The facilities needed for the cold chemical receiving and storage are the chemical handling facilities on the third and first floors of the 271-B Building (AMU area), and the scale tanks located in the operating ga11ery.

\subsubsection{Chemical Storage. The chemical storage tanks facility is located} north of the canyon and east of the 271-B service building. Table 31 ists the tanks in the farm along with the capacity, usage, and headers. The

information provided is the current specified usage of these tanks. However, these are tanks that can be used for other chemical storage, based upon their availability.

1.9.9.1.1 Nitric Acid. Three vertical stainless steel tanks, TK-SA-101, TK-SA-102, and TK-SA-103, in the 211-B Chemical Storage Area are empty. Approximately $265 \mathrm{~L}(70 \mathrm{gal})$ of nitric acid will be stored in intermediate bulk containers on the third floor of the 271-B Building.

1.9.9.1.2 Deionized Water. Tank TK-SD-111, which stores deionized water in the 211-B Chemical Storage Area, is insulated with $6.4 \mathrm{~cm}$ (2.5 in.) of calcium silicate and covered with stainless steel jacketing. A heating coil maintains the temperature near $21{ }^{\circ} \mathrm{C}\left(70^{\circ} \mathrm{F}\right)$.

1.9.9.1.3 Sodium Hydroxide. Approximately $5.68 \mathrm{~kL}$ (1500 gal.) of sodium hydroxide solution will be stored in the 271-B third floor AMU. Approximately $1.5 \mathrm{~kL}$ (400 gal.) of $\mathrm{NaOH}$ may also be stored in a gallery scale tank.

1.9.9.1.4 Sodium Nitrite. Sodium nitrite is received as a bulk dry chemical and is stored on the third floor of the 271-B Building.

1.9.9.1.5 Citric Acid. Citric acid was received as a bulk crystalline dry chemical and is stored on the third floor of the 271-B Building.

1.9.9.2 Scale Tanks in the 0perating Gallery. These tanks (Table 4) rest on scales and are located in the operating gallery. They are used to meter chemical solutions for the process. The tanks are generally of $1.5-\mathrm{kL}$ (400-ga1) operating capacity resting on a $2,722-\mathrm{kg}(6,000-1 \mathrm{~b})$ capacity scale.

\subsubsection{Aqueous Makeup Tanks. The AMU area located on the first floor of} 271-B contains two chemical tanks, $\mathrm{H}-101$ and $\mathrm{H}-102$, which are no longer used. This area is now used for receiving supplies.

The AMU area located on the third floor of 271-B contains eight tanks located within retention basins (two tanks per basin) and two tanks located on the mezzanine (Table 5). These tanks are no longer used. The third floor AMU is now used for storage of dry chemicals and houses the continuous deionization unit. 
WHC-SD-WM-TM-004 REV 1

\subsection{UTILITIES AND FIRE PROTECTION SYSTEM}

\subsubsection{Electricity}

The Bonneville Power Administration, through its substations at Vernita and White Bluffs, supplies power to the Hanford Site loop at 251-W substation A8 by $230-k V$ overhead lines equipped with static wire protection. Two independent sources are available to the loop to allow multiple component failure without irredeemable power loss. From the 251-W substation A8, with two 230-/13.8-kV transformers, power lines are routed to Site facilities via the following dual independent overhead 7 ines: $\mathrm{C} 8-\mathrm{L} 1$ through $\mathrm{C} 8-\mathrm{L} 4$ to 200 West Area and C8-L5 through C8-L8 to 200 East Area.

1.10.1.1 Main Distribution Feeders. Electric power from the 251-W substation A-8 is transmitted by two independent, 13.8-kV overhead 1ines, C8-L6 and C8-L7, to B P1ant. The powerhouse supplies 2,400 V standby power to B Plant via line E8-L66. Power for the B Plant air compressors is provided by lines $\mathrm{C} 8-\mathrm{L} 6$ and $\mathrm{C} 8-\mathrm{L} 7$ via two platform mounted substations. There is one $13.8 \mathrm{kV}$ to $2,400 \mathrm{~V} 1,000 \mathrm{kVA}$ transformer bank on each platform. The platform substations delivers 2,400 V of electrical power to B Plant on two normal lines E8-L53 and E8-L58.

1.10.1.1.1 Electrical Equipment. Substation C8-S49 is located just north of the 271-B Building. Two separate sources supply power to C8-S49, 1 ine $C 8-\mathrm{L} 6$ on Baltimore Avenue and 7 ine $\mathrm{C} 8-\mathrm{L} 7$ at the west end of the 225-B Building.

Pole-mounted, 3-pole, gang-operated load break switches, used as main disconnects from the two normal supply lines, are mounted on a dead end structure, with connections to the unit substation via underground concrete encased ducts.

Substation C8-S49 is a weatherproof, double-ended unit substation, consisting of two 1,500-kVA transformers, metal enclosed medium voltage load interrupter switch, and metal-enclosed, low-voltage drawout circuit breakers. The transformers are separated by a distance of $8 \mathrm{~m}(25 \mathrm{ft})$. Fused load interrupter switches also are used as primary disconnects to the two 1,500-kVA transformers. The unit substation has the capability of being expanded from both ends for additional 13.8-kV feeders for future loads. The low-voltage switchgear consists of metal-enclosed, 600-V circuit breakers with two 3-phase, 2,500-amp busses, each having a main incoming circuit breaker and fed from the respective 1,500 kVA transformers. A buss tie circuit breaker between these two sets of main busses is included. The two main breakers and the buss tie are electrically operated and interlocked. Under normal operation each buss is fed from its respective 1,500-kVA transformer. If either transformer or its source should fail, voltage sensing relays automatically open the main breaker of the failed source and close the tie breaker so that both busses are fed from the remaining supply. An interlock prevents a closed position for the two main breakers and the buss tie at the same time. This prevents paralleling of the two 1,500-kVA transformers. The secondaries of the 1,500-kVA transformers are $480 \mathrm{Y} / 277 \mathrm{~V}, 3$ phase, $60 \mathrm{~Hz}$ with the neutral solidly grounded. 
The low voltage main, tie breakers, and feeder breakers in the unit substation are drawout, insulated case circuit breakers with solid-state trip devices. All circuit breakers are equipped with auxiliary contacts for use with the position annunciation system. The unit substation is mounted on a concrete pad surrounded by an approved ground grid.

The transformers are nonpolychlorinated biphenyl, oil-filled outdoor type. The medium voltage switchgear is housed in a weatherproof outdoor enclosure, and the low voltage switchgear is in a walk-in weatherproof housing with internal lighting. The low voltage system is provided with a neutral buss throughout the switchgear. The available short-circuit protection from 1 ines $\mathrm{C} 8-\mathrm{L} 6$ and $\mathrm{C} 8-\mathrm{L} 7$ is $37.5 \mathrm{MVA}$ at $13.8 \mathrm{kV}$.

Electrical power within the 221-B Building is distributed at $480 \mathrm{Y} / 277 \mathrm{~V}$, 3-phase, $60 \mathrm{~Hz}$. This system has a solidly grounded neutral. Neutral conductors are brought into the building with the power conductors from the outdoor unit substation. Power is distributed throughout B Plant by a radial distribution system. Power to the MCCs is from conductors in conduit along the length of the electrical gallery, with conveniently located junction boxes for connection to the MCCs. Each feeder is installed in an individual conduit run servicing no more than two MCCs. All conduits are suitably marked at convenient intervals for identification purposes. All conductors are copper and insulated with cross-linked polyethylene or silicone rubber.

The annunciation and status indication system is installed in the $\mathrm{B} P \mathrm{Pl}$ ant dispatcher's office (271-B Building, room 205) to indicate the position of each major circuit breaker, fused disconnect, or load break switch in the B Plant electrical system. An alarm on the FPMCS indicates a deviation from a normal operating position.

1.10.1.1.2 Motor Control Center. MCCs are rated 480-V ac, three-phase, four wire. Busses are braced for 42,000 RMS symmetrical amperes. Horizontal and vertical busses are copper, and rated $600 \mathrm{~A}$ and $300 \mathrm{~A}$. A copper neutral buss and copper ground buss are provided. The circuit breakers have at least the same fault current rating as the busses. Auxiliary alarm contacts are 
provided with the main breaker for each MCC. The MCCs are effectively grounded by using a bonding jumper that connects the MCCs to the building ground grid.

Power factor capacitors are provided for all motor starters for $25 \mathrm{hp}$ or larger induction motors. Motor controllers for use in the MCCs are provided with three overload relays, which provide protection for each phase of the power conductors.

1.10.1.1.3 Lighting Distribution System. Four single-phase 480-120/240 V, 100-kVA transformers are provided for lighting. These transformers are dry-type in sealed enclosures fed individually by circuit breakers. The 42-circuit lighting panels are provided and fed by automatic transfer switches so that if one of the 100-kVA transformers fails, the associated lighting panels are automatically fed from another 100-kVA transformer until power is restored to the failed circuit, at which time the transfer switch automatically transfers the loads back to the normal supply.

1.10.1.1.4 Circuit Breakers. A11 load center main circuit breakers, a11 standby system circuit breakers (main and branch), and all transfer switches are equipped with auxiliary contacts for use with the position annunciation system.

1.10.1.2 750-kVA Generator Standby Backup. The standby 2,400-V 1 ine, E8-L66, is fed from a breaker at the $284 \mathrm{E}$ powerhouse. In the event of a power failure on the standby line, a 750-kVA steam-driven generator automatically takes over the load on the standby 1 ine. Because this line is shared throughout 200 East Area, allocation of the various operating equipment, which may be automatically switched over to the standby line, E8-L66 has been prearranged and properly authorized.

1.10.1.2.1 Standby System. An standby system compatible with the new 480-V grounded $Y$ power system was installed to supply B Plant standby loads. The system taps into the existing 2,400-V overhead standby line at pole E-181, Tocated on the south side of the 221-B Building. The 2,400-V circuit runs up the south wall of 221-B, over the roof, and down the north wall to a 300-kVA, $2,400 \mathrm{~V}-480$ y pad-mounted transformer installed at ground level on the north side of the 221-B Building. An externally mounted circuit breaker is installed on the secondary side of the transformer.

The standby distribution panel is installed in the electrical gallery. Feeders from the panel supply the following:

- The existing West End Emergency Cable Buss via an existing automatic transfer switch

- Power for the regulated voltage to the dispatcher's panel board, including the following units:

- A11 16 units on the red-colored panel alarm

- Stack activity alarm 
- Relay switch to the $38-\mathrm{cm}$ (15-in.) sewer diverter valve motor starter

- The East End Standby MCC (MCC 6A) via an existing automatic transfer switch

- Two 480-120/240 V single-phase transformers

- CAM panel board 221B-PP-CAM via an existing automatic transfer switch and transformer.

1.10.1.3 Portable Battery-Powered Lights. There are portable battery-powered lights strategically located throughout the building and plugged into the lighting circuits. Upon failure of power, these lights are energized by the battery, which Tasts $\approx 3$ hours.

1.10.1.4 Safety Consideration and Controls. In the event of a power outage on both the normal feeders, the following equipment automatically will switch to the standby feeder E8-L66:

- Instrument air compressor

- 38-cm (15-in.) monitoring system at 211-BA

- Stairwell lighting circuits

- Gallery continuous air monitors

- Alarms in the dispatcher's office

- Stack activity monitoring system in 292-B

- 221-BB condensate pit monitor and instrumentation.

It is possible for the crane to operate off the standby feeder, but this switch must be made manually. In addition, the size of the breaker in this installation limits the amount of equipment on the crane, which can be operated at the same time. It should be possible to operate the lighting, air supply monitoring instruments, and possibly the motor for one motion.

The following units are supplied directly from the E8-L66 standby feeder.

- Power for the canyon door lock solenoids on the dispatcher's desk is supplied directly and continuously from the standby feeder.

The following equipment is supplied directly and continuously from the E8-L66 standby feeder only because of manual switching arrangements made in the electrical gallery.

- Power for the regulated voltage to all panel boards.

- 38-cm (15-in.) and 61-cm (24-in.) sewer monitor and instrumentation

- F-22-9 filter monitor and instrumentation

- E-23-3 tube bundle monitor and instrumentation

- E-23-3 condensate monitor and instrumentation. 
1.10.1.4.1 Reliability of Main Distributor Feeders. The potential for a multidisability of $\mathrm{B}$ Plant protection systems is considered remote, with the potential for a pole line structure failure from lightning or other impact.

The average time to restore the power after these outages is 9 minutes. Electrical distribution personnel can be called in from their homes to the job within 45 minutes, if switching loads or other work is required.

1.10.1.4.2 Power Loss of One of the Normal Sources. In the event of a power loss of the $14 \mathrm{kV}$ sources, provisions have been made at the $480 \mathrm{~V}$ switchgear to automatically transfer the load of the failed source to the source that is still energized. This transfer will be accompanied by a 10 to 15 second loss of power to the equipment supplied by the failed source. The equipment may have to be restarted.

In addition to the indicators on the breakers, an annunciation system in the dispatcher's office monitors the breakers position. The system returns to normal configuration automatically when power is restored to the failed source. Some equipment may have to be restarted because of momentary loss of power.

1.10.1.4.3 Power Supply to Exhaust Fans. Power for the electric exhaust fans, lighting, and instrumentation at 291-B is supplied directly from the C8-L6 feeder through a transformer station in the 291-B Area. No emergency electric power supply backup is provided for this line. The automatically started, steam turbine-powered fans would then exhaust the canyon. A standby power source is available on the south side of $221-\mathrm{B}$, which provides feed to 291-BD.

Equipment in 291-BB and the turbine house that will be out of service, as a result of the C8-L6 feeder outage is as follows:

- Instrument control panels, including:

- Recorder chart drives

- Alarm signals to dispatcher's office

- Turbine running lights in dispatcher's office

- Fan bearing temperature monitor

- Filter dew point indicator and canyon exhaust relative humidity recorder located on 221-B cell 2 panel board

- Lighting, except for emergency battery lights where provided

- Space heaters and power for portable heaters in the valve pits.

1.10.1.4.4 Loss of Power to Emergency Well Houses and Cask Station. Power to the 282-B and 282-BA emergency well pump houses and 212-B Cask Station are supplied directly from the C8-L7 feeder through transformer station C8-S6, west of the 224-B Building. No emergency power supply backup is provided for this line. 
1.10.1.4.5 Emergency We11 Pumps (282-B and 282-BA). When power fails on normal feeder $C 8-L 71$ ine, there will be no power for the 282-B and 282-BA emergency wel1 pump houses. The cooling water for both diese 1 engines is kept preheated for ease in starting by auxiliary electrical heaters.

1.10.1.4.6 Cask Station (212-B). All equipment in 212-B will be without power except for emergency battery lights where provided.

\subsubsection{Steam Supply System}

Steam used in B Plant is produced in the 284-E powerhouse by three $36,000 \mathrm{~kg} / \mathrm{h}(80,000 \mathrm{lb} / \mathrm{h})$ and two $41,000 \mathrm{~kg} / \mathrm{h}(90,000 \mathrm{lb} / \mathrm{h})$ automatic stoker fired boilers at $1,720 \mathrm{kPa}\left(250 \mathrm{bf} / \mathrm{in}^{2}\right)$. Under maximum steam demand conditions, one boiler is available on a standby basis. The coal feeder drive is equipped with both electric and steam drives. The boiler feed water is monitored and sounds an alarm in the event of low water pressure. A manually operated emergency water supply system is available to prevent boiler tube damage. Steam produced in this building also is available to operate an automatic starting, steam turbine driven, $750-\mathrm{kW}$ generator located in the 284-E powerhouse.

1.10.2.1 Major Components and Operating Characteristics. The 284-E powerhouse supplies superheated $\left[1,720 \mathrm{kPa}\left(250 \mathrm{lbf} / \mathrm{in}^{2}\right.\right.$ gauge) at $232{ }^{\circ} \mathrm{C}$ $\left(450^{\circ} \mathrm{F}\right)$ ] steam to a $30.5-\mathrm{cm}(12-i n$.$) over ground line. The 30.5-\mathrm{cm}(12-i \mathrm{n}$. line divides into two lines, the $25-\mathrm{cm}(10-\mathrm{in.})$ heading west and the $15-\mathrm{cm}$ (6-in.) heading east. The $25-\mathrm{cm}(10-i n$.$) line continues around the west end$ of $B$ Plant and is reduced to an $20-\mathrm{cm}$ (8-in.) line, which enters $221-B$ in the vicinity of cell 37 on the electrical gallery level. High pressure steam $\left[1,550 \mathrm{kPa}\left(225 \mathrm{lbf} / \mathrm{in}^{2}\right.\right.$ gauge $\left.), 232{ }^{\circ} \mathrm{C}\left(450^{\circ} \mathrm{F}\right)\right]$ to the process stack area 291-B, the 222-B Building, and the 224-B Building is supplied by branches from the $25-\mathrm{cm}(10-i n)$.1 ine. There are two pressure reducing valve stations located near cells 29 and 15. High pressure steam is reduced to medium pressure steam, $690 \mathrm{kPa}\left(100 \mathrm{lbf} / \mathrm{in}^{2}\right.$ gauge $)$, at these pressure reducing valve stations. Steam at $690 \mathrm{kPa}\left(100 \mathrm{bf} / \mathrm{in}^{2}\right.$ gauge $)$ is used for process transfer jets and is supplied to 271-B Building through an 20-cm (8-in.) line, which leaves the pipe gallery in the vicinity of cell 20.

Medium pressure steam is reduced to low-pressure steam, $200 \mathrm{kPa}$ (29 $1 \mathrm{bf} / \mathrm{in}^{2}$ gauge) or $103 \mathrm{kPa}$ (15 $1 \mathrm{bf} / \mathrm{in}^{2}$ gauge), by individual pressure reducing valves for the building heating system.

Isolation valves are installed throughout the steam distribution header system for system isolation with minimum process shutdown during periods of header maintenance.

1.10.2.2 Safety Considerations and Controls. The supply of steam by the powerhouse in the 200 East Area is normally very reliable. Two or three boilers are routinely in service, but during periods of. low consumption of steam, one boiler is in service while one is on standby.

1.10.2.2.1 Loss of Steam. A complete loss of steam to B Plant could be caused by trouble at the powerhouse or rupture of the steam supply, corrosion, 
vehicle collision, or earthquake. This would require all processes and equipment to be placed on standby status until such time as the steam service is restored.

\subsubsection{Water Supply System}

The Columbia River provides the water needs for the Hanford Site. The water is pumped at the 100-B Area through an underground export water piping into the 200 East Area.

Two alternate pumping sources, located at $100-B$ and $100-D$ reactors, feed the export water pipelines and provide a redundant system, as long as the export water pipeline remains intact.

1.10.3.1 Primary Water Source (100-B Reactor Area). There are 8 electric pumps at the rated capacity of $398 \mathrm{~kL} / \mathrm{min}(10,500 \mathrm{gal} / \mathrm{min})$ per pump located at the 181-B pump house. These pumps, with a total pumping capacity of $318 \mathrm{~kL} / \mathrm{min}(84,000 \mathrm{gal} / \mathrm{min}$ ), deliver water to a 9,464-kL (25-Mgal) reservoir. The $182-B$ pump house, with 5 pumps rated at $23 \mathrm{~kL} / \mathrm{min}(6,000 \mathrm{gal} / \mathrm{min}) \mathrm{per}$ pump, pump water from the reservoir into the underground export water pipeline.

1.10.3.2 Reserve Water Source (100-D Reactor Area). There are 5 electric pumps, rated at $49 \mathrm{~kL} / \mathrm{min}(13,000 \mathrm{gal} / \mathrm{min})$ per pump, located at the $181-D$ pump house. These pumps, with a total capacity of $246 \mathrm{~kL} / \mathrm{min}(65,000 \mathrm{gal} / \mathrm{min})$, supply water to a $5,678-\mathrm{kL}(15-\mathrm{Mga}])$ reservoir. The $182-\mathrm{D}$ pump house, with two pumps rated at $8 \mathrm{~kL} / \mathrm{min}(2,000 \mathrm{gal} / \mathrm{min})$ per pump, delivers water to the export water pipeline.

1.10.3.3 Backup Water Supply. Two diesel pumps rated at $6 \mathrm{~kL} / \mathrm{min}$ $(1,500 \mathrm{gal} / \mathrm{min})$ per pump and located in $182-\mathrm{B}$ pump house, and 1 diesel pump rated at $28 \mathrm{~kL} / \mathrm{min}(7,500 \mathrm{gal} / \mathrm{min})$ and located in the $18 \mathrm{l}-\mathrm{B}$ pump 1 ine serve as backup system in the event of loss of electrical power to both the electrical pumping units located at the $100-\mathrm{B}$ and $100-0$ reactor sites. The pumps at the 100-D reactor area are the normal backup system, and the backup diesel pumps are the second backup system.

The water from both the 100-B and 100-D reactor sites is pumped through 107-cm (42-in.) concrete export water lines, which meet in the 1901-Y Area. The water supply at this juncture divides into two $76-\mathrm{cm}(30-\mathrm{in}$.) 1 ines, one of steel and the other concrete, and proceeds to the 2901-Y Area. Necessary water is allocated between the 200 Areas through two $61-\mathrm{cm}$ (24-in.) 1 ines to the 282-E Area and one 61-cm (24-in.) line to the 200 West Area. These water transport lines have valves that can be used to isolate pump houses/reservoirs and/or pipelines, ensuring a source of water to the various locations.

The main water system is connected to two 11,356-K1 (3-Mgal) reservoirs, one in 200 East Area and one in 200 West Area. From the area reservoirs, water enters either the process water system as raw water or the sanitary water system after filtering, chlorination, and testing. To meet emergency situations, area pump houses are provided with steam driven backup pumps in addition to electrically driven primary pumps. 
1.10.3.4 Water Distribution within the 200 East Area. The primary water storage facility in the 200 East Area is the 11,356-kL (3-Mgal) 282-E reservoir. Raw water is pumped from this reservoir by 4 electric pumps with a capacity of $23 \mathrm{~kL} / \mathrm{min}(6,000 \mathrm{gal} / \mathrm{min})$ per pump. There is a steam driven pump of the same capacity on standby.

1.10.3.5 Sanitary Water System. Sanitary water is produced in the 283-E filter plant, which filters and chlorinates raw water and maintains a 1,514-kL (400,000-gal) supply in an underground clear well system containing two 757-kL $(200,000-\mathrm{gal})$ concrete tanks. The water is then pumped by 4 electric pumps of $12-\mathrm{kL} / \mathrm{min}(3,200-\mathrm{gal} / \mathrm{min})$ total capacity, and two steam turbine pumps (standby status) with a $4.5-\mathrm{kL} / \mathrm{min}(1,200-\mathrm{gal} / \mathrm{min}$ ) total capacity.

Sanitary water is used in B Plant for safety showers, operating area wash down, drinking, toilet facilities, making deionized water (refer to Section 1.10.4) for process use, and as an emergency backup for fire fighting. Included in the system is a 189-kL $(50,000-\mathrm{gal})$ high tank located southwest of the building to ensure continued availability of water under pressure. The sanitary water enters the building at the west end through an $20-\mathrm{cm}$ (8-in.) header valve (47-S) and the header extends along the length of the building.

1.10.3.6 Raw Water System. Raw water is used at B Plant as a heat transfer fluid in cooling coils for process and storage tanks, condensers for the concentrator, air compressors, and diesel engines. Raw water also is used for sprays, filter seals, and fire protection.

The raw water for 221-B enters the building at both the east and west ends via $25-\mathrm{cm}(10-i n$.$) headers. The pressure at both the east and west ends$ of the $221-\mathrm{B}$ operating gallery is $690 \mathrm{kPa}\left(\approx 1001 \mathrm{bf} / \mathrm{in}^{2}\right.$ gauge $)$. Both $5-\mathrm{cm}$ and $8-\mathrm{cm}(2-\mathrm{in}$. and $3-\mathrm{in}$.$) lines that serve each cell within the 221-B canyon$ exit from the $25-\mathrm{cm}(10-i n$.$) header. Raw water discharging from either 221-B$ or 225-B enters the cooling water drain system via either one of two header systems, which is a $61-\mathrm{cm}$ (24-in.) line or a $38-\mathrm{cm}(15-$ in.) line.

1.10.3.6.1 Low Potential. The 61-cm (24-in.) cooling water line receives discharges from those vessels considered to have low potential for possible contact with radioactive solutions.

1.10.3.6.2 High Potential. The $38-\mathrm{cm}$ (15-in.) cooling water line receives discharges primarily from tank cooling coils that have a high concentration of radioactive solution. Radiation monitors are located on each subheader and header.

1.10.3.7 Backup Pumps. Two diesel-driven backup emergency we11 pumps identified as \#1 (282-B) and \#2 (282-BA) are located west of 225-B at wells 299-E28-11 and 299-E28-15. In the event of loss of raw water supply to B Plant, these pumps will be used to supply a minimum volume of raw water. These pumps are controlled by the Waste Encapsulation and Storage Facility (WESF) and thus are part of the safety basis for that facility.

Well 299-E28-11 has an 20-cm (8-in.) casing drilled from an initial elevation of $214 \mathrm{~m}(701 \mathrm{ft})$ to a depth of $106 \mathrm{~m}(347 \mathrm{ft})$. The well was completed in 1962 . 
Well 299-E28-15 has a 30.5-cm (12-in.) diameter casing and was drilled to a depth of $107 \mathrm{~m}(350 \mathrm{ft})$ from an initial elevation of $214 \mathrm{~m}(701 \mathrm{ft})$. Actual depth to the water is $90 \mathrm{~m}(295 \mathrm{ft})$. The well was completed in 1968. Each well is sampled for total beta, total alpha, ${ }^{137} \mathrm{Cs}$, and $\mathrm{NO}_{3}$.

\subsubsection{Deionized Water}

Deionized water is required primarily at the WESF for pool cell makeup water and at both B Plant and WESF for dry chemical makeups, tank flushes, and general miscellaneous use. WESF requires deionized water quality to be $<4.5 \mu \mathrm{S} / \mathrm{cm}$. Average use is $19 \mathrm{~kL}(5,000 \mathrm{gal})$ per month but the system is capable of supplying up to $76 \mathrm{~kL}(20,000 \mathrm{gal})$ per month.

Deionized water is produced by a continuous deionizer unit. Sanitary water is passed through a series of skid-mounted pretreatment components to purify the water to an acceptable quality, which will prevent scaling of the continuous deionizer unit. Water is first passed through a multimedia filter, which removes silt and particles. Next, the water flows through a carbon filter, which removes chlorine and some organics. Water then flows through a primary softener to remove calcium, magnesium, and iron. An organic scavenger is then used to remove remaining dissolved organic matter. Finally, a polishing softener is used to protect against failure or improper regeneration of the upstream primary softener unit. A set of $5-\mu$ filters and a set of $1-\mu$ filters are used to collect any particles that may break free of the previous filters.

The deionization is accomplished by a continuous deionization unit. The process operates by passing feed water through mixed ion-exchange resins sandwiched between an anion and cation exchange membrane. Continuous direct current across the electrodes causes water molecules to break down. Free hydrogen and hydroxide ions replace the retained anions and cations. As the retained ions leave the resin surface, the electric current drives them through the ion-exchange membrane to the waste stream. Control of the system is provided by a wall-mounted controller and individual timers, which regenerate the pretreatment equipment. A wall-mounted panel provides local indication of the feed water and product water quality, as well as flow rate and a flow totalizer. This panel also provides these signals to the FPMCS.

The system is self-regenerating and requires only monitoring and periodic brine salt additions.

Deionized water is supplied to both the 111 No. 1 header and the 111 No. 2 header. The 111 No. 1 header extends the length of the pipe gallery and supplies deionized water to the AMUs, the scale tanks, diptube flush legs, and WESF. The 111 No. 2 header supplies deionized water to tank TK-SD-111, a $68-k L(18,000-g a 1)$ backup supply tank located in the 211-B Chemical Storage. Tank TK-SD-111 has an electric $189-\mathrm{L} / \mathrm{min}(50-\mathrm{gal} / \mathrm{min})$ pump and a portable gas pump as a backup and is tied directly to the 111 No. 1 header. 


\subsubsection{Compressed Air Systems}

B Plant has the following completely separate compressed air systems.

- Process air system (RHO 1971). This system supplies requirements for air jets, jet-air-blow system, process coil purging, air sparger systems, air-operated tools, etc. It also is used as a final backup for the instrument air system.

- Instrument air system (Worthington 1967). This system is used for pneumatic signal transmission, for purge air in instrumentation, for air motor controls on ventilation equipment, and for specialized calibration requirements.

1.10.5.1 Process Air System. Two rotary screw heavy duty compressors located in the 271-B basement provide compressed air for process use. Each compressor is capable of delivering $35.1 \mathrm{~m}^{3} / \mathrm{min}\left(1,240 \mathrm{std} \mathrm{ft}^{3} / \mathrm{min}\right)$ of air at $760 \mathrm{kPa}$ (110 1bf/in ${ }^{2}$ gauge) within a $69-\mathrm{kPa}\left(10-1 \mathrm{~b} / \mathrm{in}^{2}\right)$ differential. only one of these compressors is used during normal operation.

There is a common air intake manifold with a filter that serves both the rotary compressors. Compressed air flows through one of the two after coolers and oil separators into $21-\mathrm{m}(4-\mathrm{ft})$ outside diameter by $4-\mathrm{m}$ (12-ft) receiver tanks. The process air then flows through a $30.5-\mathrm{cm}(12-\mathrm{in}$.$) 1ine to the main$ header that runs the length of the operating gallery. Numerous subheaders and feeders branch out from the main header.

Process air is used to operate the exhaust jets on the vessel vent system, which is provided to contain and decontaminate off gases before discharge to the environment. Process air is used for operating the process solution recirculation jets located in the sampling ports of the canyon deck.

1.10.5.2 Instrument Air System. One reciprocating compressor rated at $9.3 \mathrm{~m}^{3} / \mathrm{min}$ (330 std $\mathrm{ft}^{3} / \mathrm{min}$ ) capacity supplies instrument air at $760 \mathrm{kPa}$ (110 $\mathrm{lbf} / \mathrm{in}^{2}$ gauge). The compressor, in the electrical gallery, takes suction through an 20-cm (8-in.) filter located above grade near the stairwell 15 entrance. The air flows through an inside air receiver to the 2 cylindrical 1-m (4-ft) diameter by 4-m (12-ft) tanks located outside 271-B. The air is passed through a dryer in the electrical gallery, and the pressure reduced by two diaphragm-operated valves from 690 to $450 \mathrm{kPa}$ (100 to $65 \mathrm{lbf} / \mathrm{in}^{2}$ gauge) before flowing to the main header running the length of the operating gallery. Several $1-\mathrm{cm}(0.5-i n$.$) lines branch off these main 8-\mathrm{cm}$ (3-in.) headers to service various systems and instruments requiring instrument air.

Instrument air is used for air purging the weight factor and specific gravity dip tubes, for controlling diaphragm-operated valves, and for a variety of pneumatic instrumentation, including pressure indicators, recorders, recorder controllers, transducers, and transmitters. There is a cross-tie between B Plant instrument air and WESF instrument air.

1.10.5.3 Intertie Between Process and Instrument Air. On low pressure a diaphragm-operated valve on the process air intertie line opens to the main instrument air system through an oil separator at full continuous pressure. 
1.10.5.4 Usage of Process and Instrument Air. Aqueous solutions containing fission products generate hydrogen gas by radiolysis. Dilution air is provided in the tanks, if needed, to maintain the vessel atmosphere below the lower explosive limit. Process air is required for purging gang valves and supply lines to the steam jets after usage to prevent their filling with process solution, as a result of the vacuum caused by condensed steam.

1.10.5.5 Complete Loss of Air Supply. The primary ventilation exhaust fan damper settings at 291-B are controlled by pneumatic instrumentation and arrangements are provided for a fail-safe condition in the event of loss of instrument air supply. The electric motor driven exhaust fans are stopped and their dampers closed.

Plant design criteria require that all air-operated valves be left in a safe position in the event of loss of instrument supply.

1.10.5.6 Loss of Process or Instrument Air. Loss of instrument air supply could be caused by a complete electrical power failure; a mechanical breakdown of the compressors, or a break in the distribution lines from the compressed air tank.

In the event of an interruption of electrical power to the instrument air compressor, power can be supplied to the compressor from the 200 East steam turbine via the standby 2,400-V power line E8-L66. If a mechanical breakdown or a break in the distribution lines of the instrument air compressor occurs, a cross-tie between the process and instrument air systems will allow the supply of process air to instrument systems. The two process air compressors have a total capacity of $70 \mathrm{~m}^{3} / \mathrm{min}\left(\approx 2,480 \mathrm{ft}^{3} / \mathrm{min}\right)$, which is sufficient to supply both air systems.

During normal operation of the process air compressors, one unit is operational while the other is in standby. The standby unit can replace the operating compressor if a mechanical failure occurs.

\subsubsection{Fire Protection System}

The fire protection system encompasses fire prevention, detection, annunciation, control, confinement, suppression, and extinguishment in addition to administrative procedures. There are no accident analyses that require any of the fire prevention, detection or suppression systems (Lee 1972, 1976, Falbert 1980; Gaskill 1972, and Miller 1973).

The fire protection systems of $\mathrm{B}$ Plant are described in the following sections. Systems provided include standard wet and dry automatic sprinkler systems, and a light water aqueous-film foaming deluge system. Smoke detectors, heat detectors, manual pull boxes, portable fire extinguishers and fire hydrants are located within the facility.

1.10.6.1 Causes of Fire. Identified potential causes of fires at B Plant include the following:

- Electrical. Failure of equipment or wiring. 
- Improper Handling. Highly flammable materials such as hydrogen, flammable solvents.

- Thermally Hot Surfaces. Enclosures are provided for heating elements of furnaces, ovens, hot plates, or other heating devices. High temperature cutoff safety circuits are provided independently of normal controls. By administrative control and safety rules, heat producing devices (e.g., motors, ovens, hot plates, soldering irons, and direct flame devices) must be used and located away from combustible materials.

- Spontaneous Ignition. Fires arising from spontaneous combustion of Class $A$ material are not expected to be a significant problem because quantities of stored fuel or packaged waste (oil-soaked rags, sensitized resins) are limited.

\subsubsection{Water Supply for Fire Protection System. The fire protection} systems at B Plant are supplied by raw water. Raw water can also be supplied by the diesel pumps.

1.10.6.2.1 Coordination with 225-B. Close coordination between the operating management of $\mathrm{B} P \mathrm{Pl}$ ant and WESF is required throughout the raw water failure to allocate the $\approx 4 \mathrm{~kL} / \mathrm{min}(\approx 1,000 \mathrm{gal} / \mathrm{min})$ in water supply from the emergency well pumps. When the B Plant emergency shutdown has progressed to the point that raw water header pressure has increased up to about $276 \mathrm{kPa}$ (40 $\mathrm{lb} / \mathrm{in}^{2}$ ), 225-B management is notified to resume raw water to the pool cel1 heat exchangers. The flows are manually controlled and held to a minimum, but they are adequate to prevent temperature excursions.

1.10.6.3 Building Features. B Plant and its auxiliary support facilities structures are divided into the following three sectors for fire detection. The dispatcher's office serves as the central information and control center.

- 271-B Service Building, Portions of 221-B Canyon Structure, and Auxiliary Structures. This sector is divided into seven zones basement, first floor, second floor, change room facilities at the east end of the operating gallery together with the special work permit clothes storage room on the pipe gallery level, 272-B maintenance, and 272-BB insulation shop.

- 221-B Canyon Structure and Cells. The panel for the cell fire protection system is located in the pipe gallery at cel1 25 .

- Exhaust Air Filter Area. This area is divided into three zones. Zone I consists of the 291-B Fan Control Room, 291-BB Exhaust Air instrument house, and 291-BD Exhaust Air third filter cell and instrument house. Zone II consists of 221-BD 1aundry storage, 221-BB process and steam condensate, and 221-BC change house. Zone III includes the exhaust tunnel heat detectors and tunnel sprays.

1.10.6.3.1 Fire Detector and Supervisory Control Pane1. These signal red control panels with a key-lockable door are surface mounted and supplied with the following door-mounted equipment. 
- $A C$ power on indicating lights - white

- Zone fire alarm indicating lights - red

The fire alarm activating device actuates the fire alarm common contacts (including notice to the Hanford Fire Department), lights the appropriate zone-indicating lamps and where applicable activates the suppression system.

- Zone trouble indicating lights - amber

A signal lights the appropriate zone trouble indicating lamp, closes an auxiliary contact to light the fire alarm control panel troubleindicating lamp on the supervisory panel, actuates the supervisory common contacts, and sounds an audible alarm at the panel.

- Single lamp test push button.

1.10.6.3.2 Normal Power. The normal power for the fire protection system consists of $120 / 240 \mathrm{~V} A C$ source. The $120-\mathrm{V}$ circuits are designated as primary and supervisory sources. The primary source operates all fire alarm circuits and is supervised.

There is an emergency fire alarm within the 271-B services and parts of 221-B Canyon structure building. The fire bell is activated by the overhead sprinklers and/or fire alarm pull boxes. Personnel are alerted of an emergency situation in 271-B by a fast-ringing call bell for a duration of 3 minutes.

1.10.6.3.3 Emergency Power. An emergency source of rechargeable batteries is provided for the control panels. The battery assemblies have been sized to operate a system for a minimum of 60 hours after loss of charging current and are capable of sustaining a load of $5 \mathrm{~A}$ for a minimum of I minute in addition to the load of the control panel at the end of the period. The batteries are housed in properly vented metal enclosures mounted on the wall.

The battery charger is a completely automatic, solid-state, constant-voltage device to carry continuous and intermittent loads up to its rated maximum output. The charger is capable of charging batteries from $75 \%$ of ful1 charge to $100 \%$ of full charge within 24 hours.

1.10.6.4 221-B Canyon Structure and 271-B Services Building. These buildings have a construction classification of fire resistance and an occupancy classification of special purpose industrial/business.

1.10.6.4.1 271-B Services Building Facility. This building is protected with a wet pipe automatic sprinkler system that alarms directly to the Hanford Fire Department. The building also is equipped with manual puTl boxes located along the common egress routes. Activating any one box will sound an audible alarm, and an alarm will be transmitted to the Hanford Fire Department. The building has an adequate number and type of portable fire extinguishers located strategicaliy throughout. 
The east and west exit stair enclosures are $\mathrm{Cl}$ ass $\mathrm{B}, 1.5-\mathrm{hr}$ rated. East corridor doors on the first level are Class $C, .75 \mathrm{hr}$ rated, self-closing fire doors and assemblies. All the pipe penetrations in stair enclosures, corridors, and pipe chase floor penetrations are sealed with an approved sealant. Smoke detector actuated dampers annunciate at the fire panel in the first level of the west corridor.

1.10.6.4.2 221-B Canyon Structure Facility. The change room located in the operating gallery at the east end of the facility is protected with a wet pipe automatic sprinkler system having that alarms directly to the Hanford Fire Department. The system also transmits an alarm to the dispatcher's office in 271-B. Cells 26 through 30 , which contain organic solvents, and Cell 10 are protected with a light water, aqueous film forming foam, automatic (or manual) fire suppression system. The accident analyses do not require that this system be maintained operable.

There are eight doors and stairwells on the north side of 22I-B and doors through 271-B into the pipe gallery, operating gallery, and the basement. There are 21 doors into the canyon. One of these doors is through the change room, and the rest are on the south side and have to be opened electrically by operations personnel from within the building.

Doors to stairwells are fire rated ( $C l a s s ~ B, 1.5 \mathrm{hr}$ ), allowing entrance from 221-B to 271-B. The 221-B to 271-B smoke dampers have fusible link closure mechanisms and will be activated by smoke detectors. Penetrations in fire barriers throughout facility are being reviewed for possible upgrade to maintain the integrity of the fire barrier in which they are located and 1.5-hr rated smoke dampers are installed in the ducts penetrating the wall.

The 291-B filter fire protection system is activated either automatically by heat detection devices or manually from the dispatcher's office. Automatic activation of the system results if both heat detectors in the 291-B wind tunnel duct are tripped by a heat source or if both the detectors in any of cells 10 or 26 through 30 are tripped. The fire protection system includes the following features.

- Dual Heat Detectors. Dual heat detectors are located in 221-B processing ce $11 \mathrm{~s} 10$ and 26 through 30 , which contain organic solvent. Foam spray is activated to one or more cells through the upper cell sprays upon response to heat detectors. The accident analyses do not require this system to be maintained operable.

- Fire Alarm Relay. Fire alarm is automatically relayed to the Hanford Fire Department.

- Tunnel Heat Detectors. Two heat detectors are located in the wind tunnel. A $19-\mathrm{L} / \mathrm{min}$ (5-gal/min) water fog spray in the wind tunnel responds automatically to a fire and a $189-\mathrm{L} / \mathrm{min}(50-\mathrm{gal} / \mathrm{min})$ water fog spray can be turned on manually after hose connections are made. The accident analyses found that this system is not required to be maintained in an operable condition. 


\subsubsection{Cell Foam Systems and 291-B Exhaust Ventilation Systems Fire Protection.}

1.10.6.5.1 Cell Foam System. The accident analyses found that this system is not required to be operable as a mitigating feature to an accident.

The heat detectors in cells 10 and 26 through 30 are dual element jumpers. Activation of both elements in the dual heat detectors will activate the foam spray into the cell and the $19-\mathrm{L} / \mathrm{min}(5-\mathrm{gal} / \mathrm{min})$ fog nozzle in the wind tunnel. Once the flow of foam to a cell is activated, it will continue on a timer or until the manual switch on the dispatcher's panel has been turned to spray stop. If flow is discontinued by the timer and the heat detectors still sense a fire, the foam system will activate again. The valves to an individual cell may be operated manually to start and stop the flow of foam to the cells.

1.10.6.5.2 291-B Exhaust Ventilation Fire Protection Systems. Two heat detectors are installed in the 291-B duct. One is installed in the access hole just south of 221-B, and the other is located in the turbine inlet duct downstream of the filters. When either of these detectors is activated by a heat source, the valves for filling the $D$ filter outlet seal are manually activated, the $19-\mathrm{L} / \mathrm{min}(5-\mathrm{gal} / \mathrm{min})$ fog nozzle operates, the canyon supply fan units shut off, and a signal is sent to the Hanford Fire Department. The $189-\mathrm{L} / \mathrm{min}(50-\mathrm{gal} / \mathrm{min})$ tunnel spray down stream of the $19-\mathrm{L} / \mathrm{min}(5-\mathrm{gal} / \mathrm{min})$ spray system, is manually operated, and Operations personnel are required to physically hook up hoses and open the related valves. Alarms in the dispatcher's office will indicate motorized valve operation, seal water level in the outlet seal, fog nozzle operation, and operation of the pressure isolation valve.

When the heat detectors in cells other than the foam equipped cells are activated, there will be an alarm sent to the Hanford Fire Department and the alarm will register on the FPMCS. The airflow will be diverted manually through the sand filter, and the canyon supply fans will be shut down.

1.10.6.6 221-B Process and Condensate Building. This building has smoke detectors with a direct alarm to the Hanford Fire Department. The buitding also has manual pull boxes and portable fire extinguishers.

1.10.6.7 212-B Cask Loading Stations Facility. The fire protection system for 212-B includes alarm boxes, overhead sprinkler lines, heat detectors, and fire extinguishers (Grady and Kirkman 1971).

1.10.6.8 291-B Exhaust Fan Control House. This building is equipped with a smoke detector and manual pull box having a direct alarm to the Hanford Fire Department. The building also has portable fire extinguishers.

1.10.6.9 221-BF Effluent Control Building. There is no fire protection system.

1.10.6.10 282-B and 282-BA Emergency Well Pump Houses. Both buildings have smoke detectors with a direct alarm to the Hanford Fire Department and also have portable fire extinguishers. 


\subsection{CANYON CRANE}

The B Plant canyon is provided with an electrically operated overhead bridge crane (Marusich 1989).

\subsubsection{Crane}

The crane is located on rails that extend the entire length of the canyon. The main trolley sits on top of the bridge and travels between the south wall of the canyon and the parapet on the north. The trolley is equipped with two hoists: a 45-ton main hoist and a 10-ton auxiliary hoist. The 10-ton auxiliary hoist is fitted with an electrically operated rotary hook. The crane also has four auxiliary hoist units attached on two monorails below the bridge for lifting lighter objects. Each monorail trolley carries two hoists, a l-ton hook, and a .5-ton impact wrench. The bridge, the three trolleys, the six hoists, the rotary hook, and the two impact wrenches are controlled from the crane cab.

\subsubsection{Rotary Crane Hook}

The 10-ton rotary hook was designed to allow the crane greater versatility. A $115-V$ dc gear motor drives the hook through a slip clutch set at $10 \mathrm{~m}-\mathrm{kg}$ (60 ft-1b) maximum torque. The load is transmitted from the block by a tapered roller bearing.

\subsubsection{Crane Optical Aids}

Two optical systems, one on each side of the crane bridge, permit the operator to view the crane hooks, impact wrenches, and cell equipment. Although the field of vision is rather limited (to gain magnification), scanning may be obtained at the operator's discretion by electric motors that telescope the optics across the canyon, and rotate them on their axis. The eye pieces are automatically synchronized with the viewing direction of the objective ends of the optics, so the operator is always looking in the true direction. The optics are equipped with three settings - 1ow, medium, and high - that can be switched as needed by the crane operator.

The crane is equipped with two radio-frequency video cameras. One camera is attached to the east-monorail trolley with pan and tilt functions for general overhead viewing of crane work and canyon activities. The other camera is suspended from the hook off the west-monorail trolley. This camera is equipped with pan and tilt functions and can be moved up and down for viewing cell work, completing inspections, and maintaining configuration control.

\subsubsection{Crane Maintenance Platforms}

A mobile crane-maintenance platform is provided to service the crane. The platform is mounted on a short section of rails at the east end of the canyon and is propelled by driving the wheels with a hand crank mechanism. Access to the platform is provided by a fixed catwalk mounted at the east end 
of the canyon. The platform is of split-level design. This allows maintenance of the crane on the upper level while permitting the maintenance platform to pass under the crane simply by positioning the main trolley above the lower level of the platform.

\subsubsection{Electrical Services}

The crane is supplied with 480-V, 3-phase, 60-cycle power via conductors and collector shoes mounted on the crane. Similar conductors and collectors supply power to the trolley. Each monorail trolley is supplied by festooned cables. The rotary hook, impact wrenches, and grabbers are supplied through reel type cord retractors. The cab is equipped with a radio telephone and a private automatic exchange telephone.

\subsection{REFERENCES}

Buckingham, J. S., 1967, Waste Management Technical Manual, IS0-100, Waste Management Process Engineering, Research and Engineering, ISOCHEM, Inc., Richland, Washington.

Burchsted, C. A., J. E. Kahn, A. B. Fuller, 1976, Nuclear Air Cleaning Handbook, "Design, Construction and Testing of High-Efficiency Air Cleaning Systems for Nuclear Applications," ERDA-76-21, Energy Research and Development Administration, Washington, D.C.

Castle, G. K., 1973, "Fire Protection of Structural Steel," Loss Prevention, Vol. 8, Avio Systems Division, Avco Corp., Lowe11, Massachusetts.

CFC, 1963, Exhaust Steam Turbine Fan G.E. H3C-888-4-1-594, CVI 13902, C7arage Fan Company, Kalamazoo, Michigan.

Falbert, J. H., 1980, "Fire Hazards and Consequences of Fires in Nuclear Power Plants," Nuclear Safety, Vol. 21, No. 1, by NATLSC0, Long Grove, Illinois.

Fecht, F. B., et a1., 1973, Hazard Review - Improved Fire Protection - B Plant Exhaust Filters - Project HCP-664, ARH-2918, Atlantic Richfield Hanford Company, Richland, Washington.

Fecht, F. B., et a1., 1974, Hazards Review - B Plant Filter System, ARH-CD-105, Atlantic Richfield Hanford Company, Richland, Washington.

Fecht, F. B., et al., 1975, Hazards Review - Waste Management Effluent Controls - B Plant Fourth Filter - Project B-1120, ARH-CD-352, Atlantic Richfield Hanford Company, Richland, Washington.

Gaskill, J. R., et al., 1972, "Fire Protection of HEPA Filters by Using Water Sprays, " CONF-720823, University of California, Lawrence Livermore Laboratory, Livermore, California (12th AEC Air Cleaning Conference).

GBC, 1966, Model 88-8-024 (EPN-291-B-K2-1 and EPN-291-B-K2-2), CVI 14869, (P.0. JAJ-D-50560), General Blower Company, Wheeling, Illinois. 
Gehrke, J. W., 1992, "Preliminary Estimate of Revised 291B Filter Inventories Based on Unreviewed Safety Question Investigation," (Internal letter 16143-92-284-JWG to W. W. Bowen, October 14), Westinghouse Hanford Company, Richland, Washington.

Gehrke, J. W., 1993, "Revised Inventory Estimates for B Plant Unreviewed Safety Question Safety Analysis Based on A Filter Flooding Incident," (Internal letter 16430-93-009-JWG to R. M. Marusich, January 18), Westinghouse Hanford Company, Richland, Washington.

Grady, Jr., B. J., and H. J. Kirkman, 1971, 212-B Cask Station Information Manual, ARH-1690, Waste Management Process Engineering, Atlantic Richfield Hanford Company, Richland, Washington.

Lee, H. A., 1972, "Fire Protection in Caves, Canyons and Hot Cells," CONF-720823, Atlantic Richfield Hanford Company, Richland, Washington (12th AEC Air Cleaning Conference).

Lee, H. A., 1976, Guide to Fire Protection in Caves, Canyons, and Hot Cells, ARH-3020, Atlantic Richfield Hanford Company, Richland, Washington.

Marusich, R. M., 1989, "B Plant SAR Chapter 9 Review for Crane Upgrade Impact" (internal 1etter to L. M. Swanson, Apri1 19), Westinghouse Hanford Company, Richland, Washington.

Miller, M. J., 1973, "Reliability of Fire Protection Systems," Loss Prevention, Vol. 8, Factory Mutual Research Corp., Norwood, Massachusetts.

RHO, 1969, B Plant Equipment and Facilities Information Manual, Rockwell Hanford Operations, Richland, Washington.

RHO, 1971, Procurement Specifications for Stand-by, Diese7-Engine-Driven, Deep-Well Pump Building 282-BA, Project HAP-631, HWS-8977, Rockwell Hanford Operations, Richland, Washington.

Rourke, J. F., 1973, "The Use of Intumescent Coatings for Fire Protection of Structural Steel," Loss Prevention, Vol. 8, Alki Hamef. Corp., Subs., Cities Service Company, Rockville, Connecticut.

Swanson, L. M., 1989, Preliminary Safety Analysis Report for Project W-008, B Plant Chemical Sewer Neutralization System, WHC-SD-W008-PSAR-001, Westinghouse Hanford Company, Richland, Washington.

Worthington, 1967, Feather Valve Compressors, Vertical Unit VBB-(12 $\times 9$ 9) L-86000T, 3600-EIV-0, Worthington Corporation, Buffalo, New York. 
Figure 1. B Plant, Waste Encapsulation and Storage Facility, and Auxiliary Facilities.

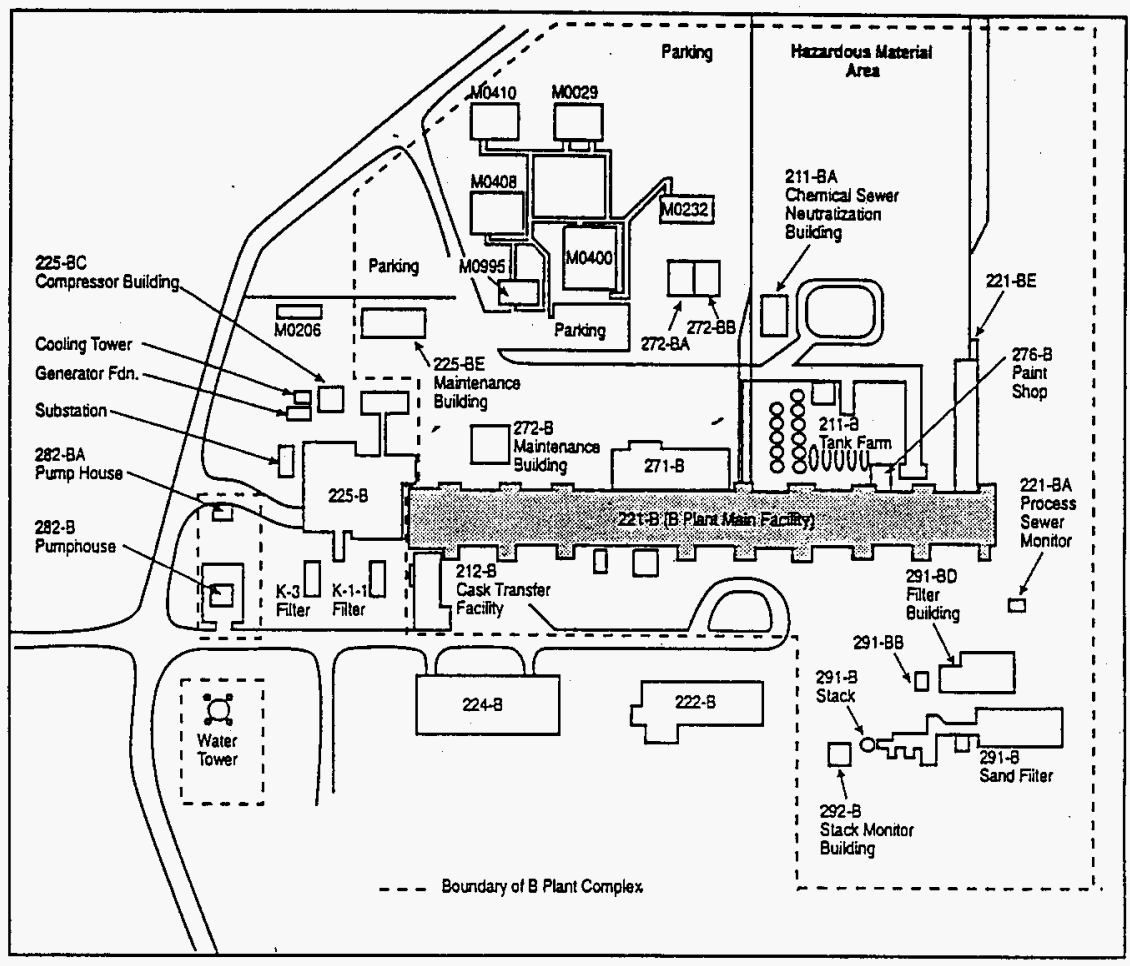

R9505058.1 
Figure 2. Floor Plans of the 271-B Service Building.

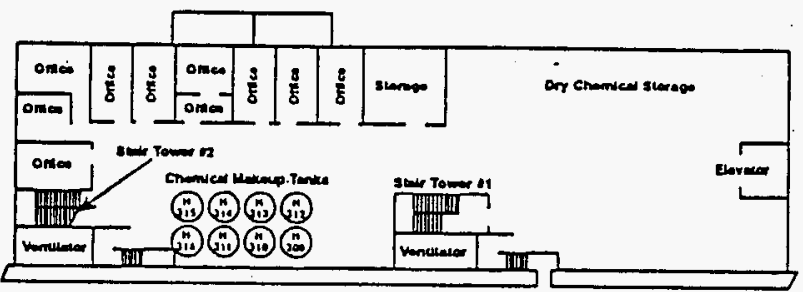

271-B Third Floor Plan
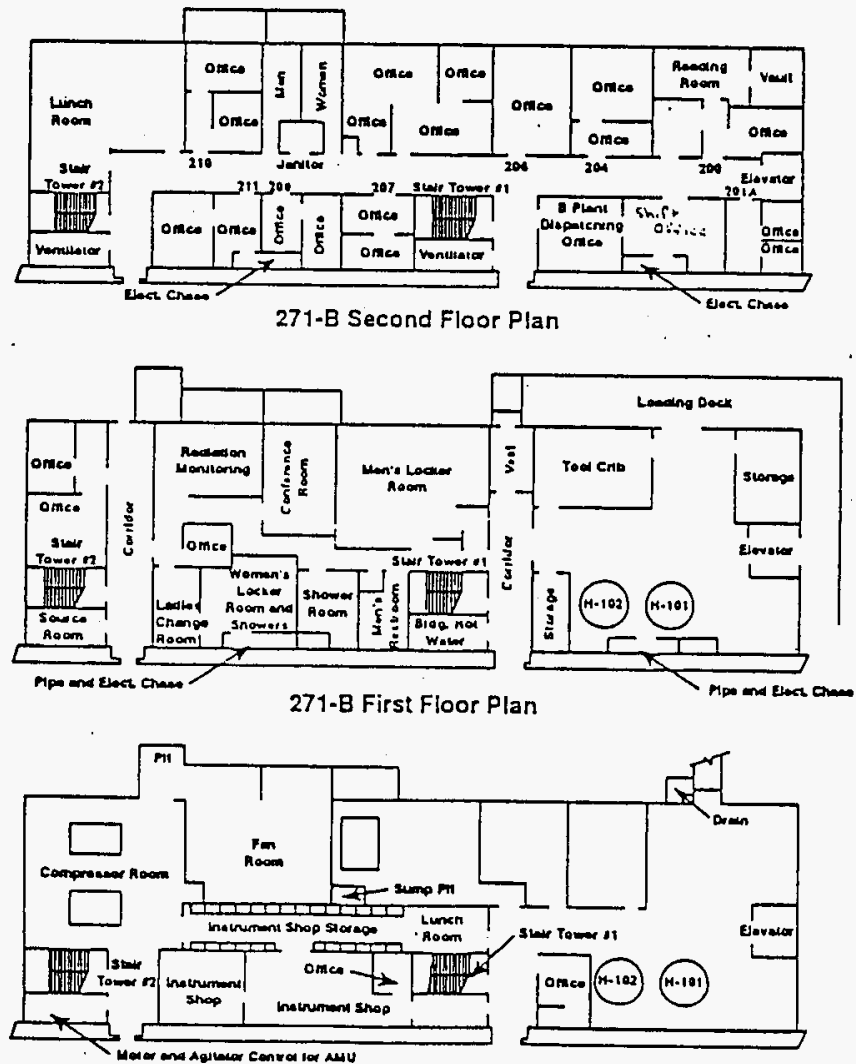

271-B.Basement Floor Plan 
Figure 3. Typical Cross-Section of 271-B Service Building and 221-B Canyon Structure.

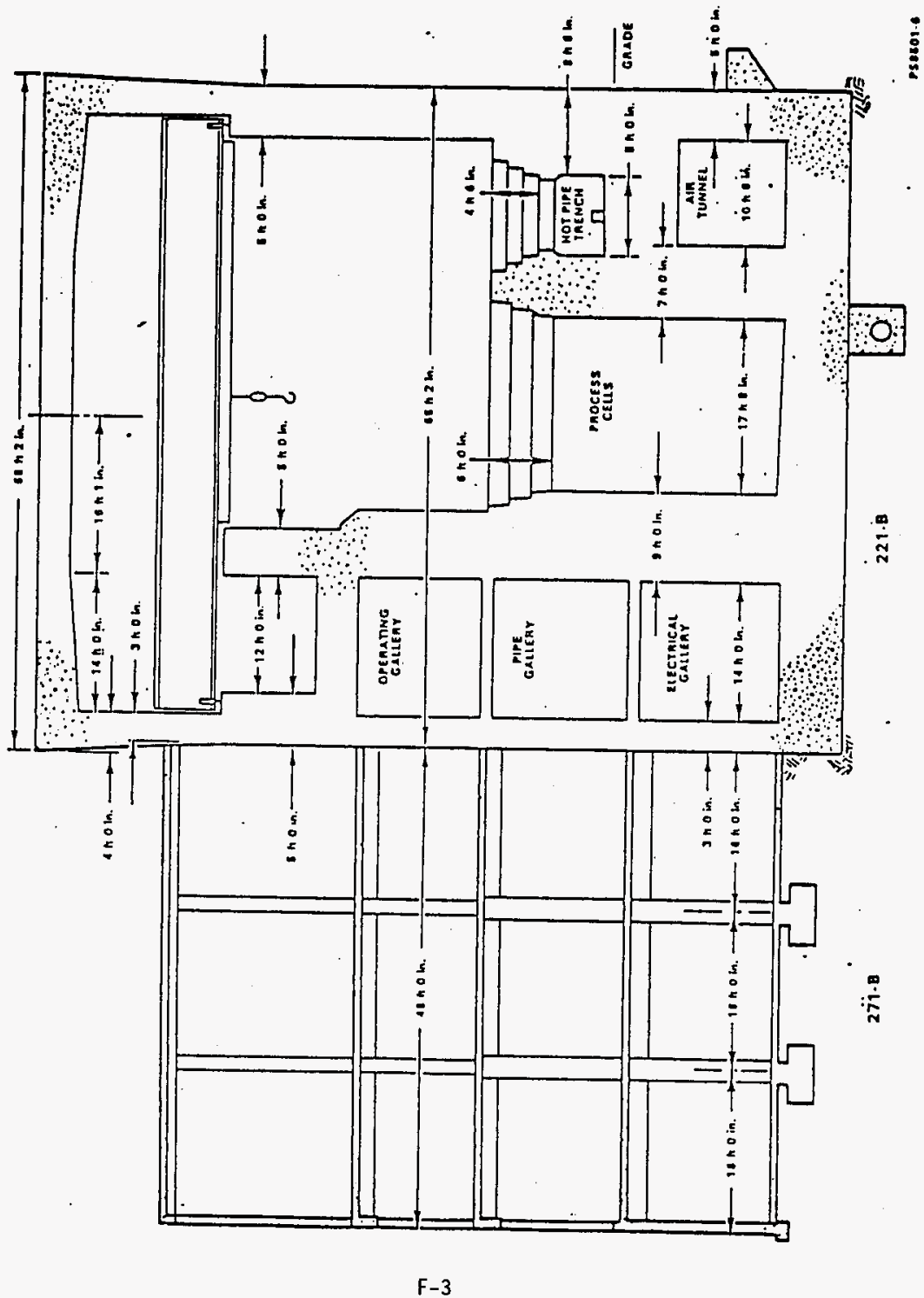


Figure 4. Cross-Section of 221-B Building.

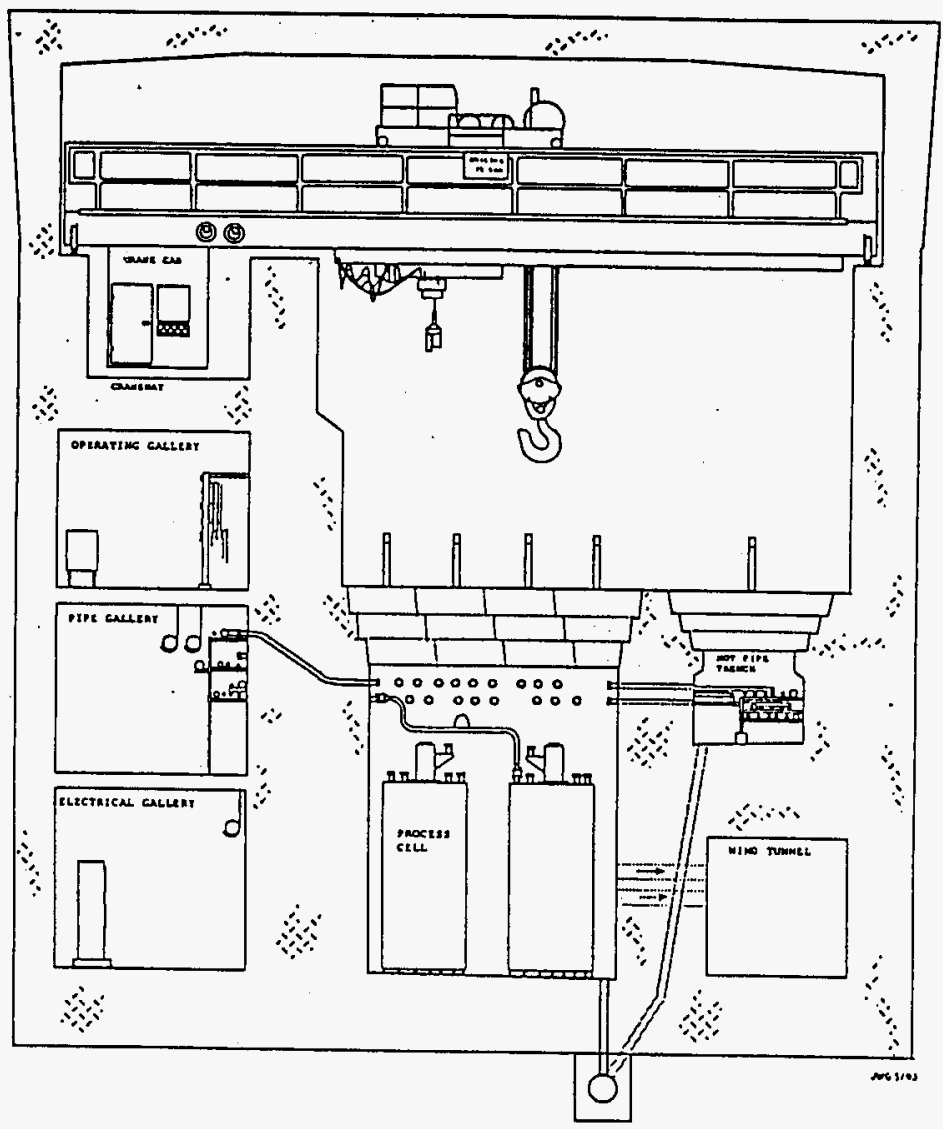




\section{WHC-SD-WM-TM-004 REV I}

Figure 5. Nonprocess Cell 3, Railroad Tunnel.

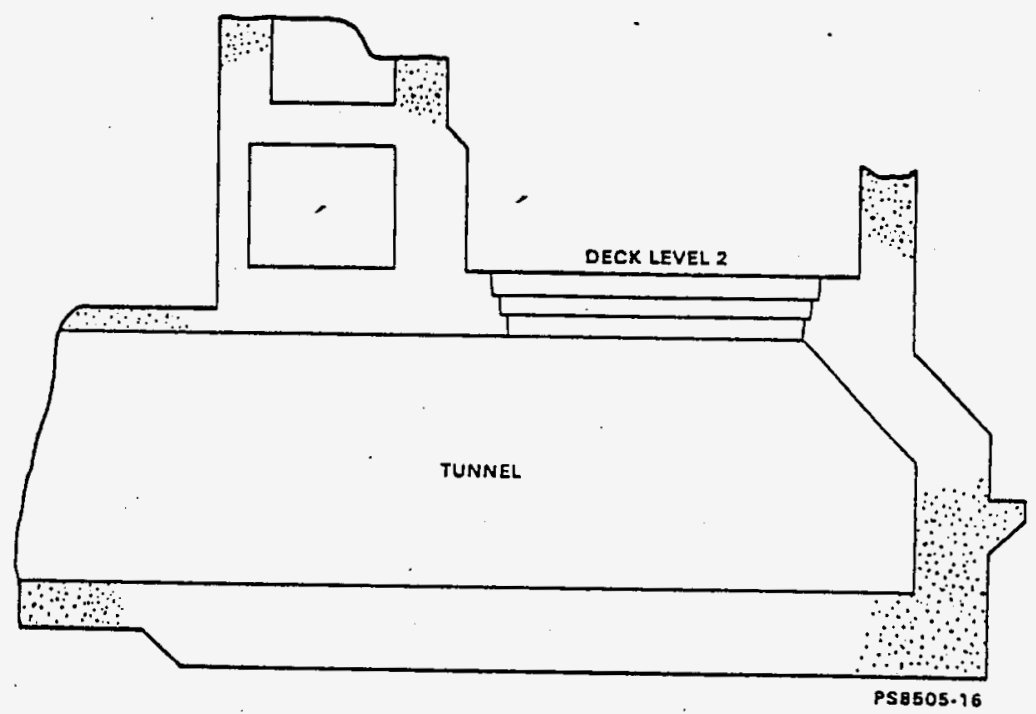


Figure 6. Nonprocess Cell 4, Waste Encapsulation and Storage Facility Solid Waste Drum Interim Storage.

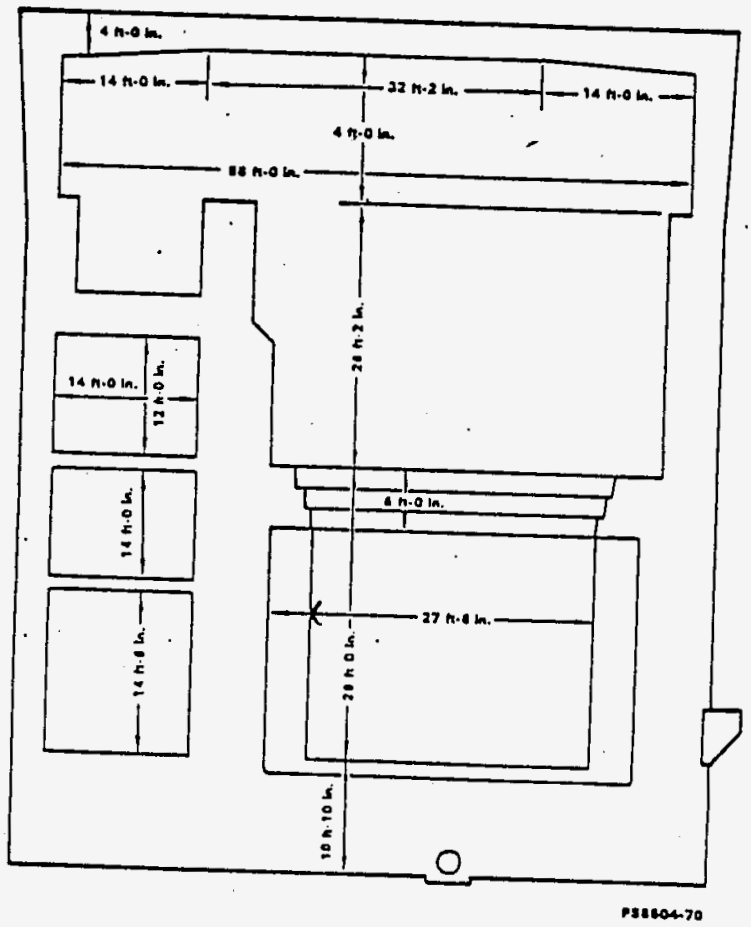


Figure 7. Nonprocess Cell 40, Sample Cave.
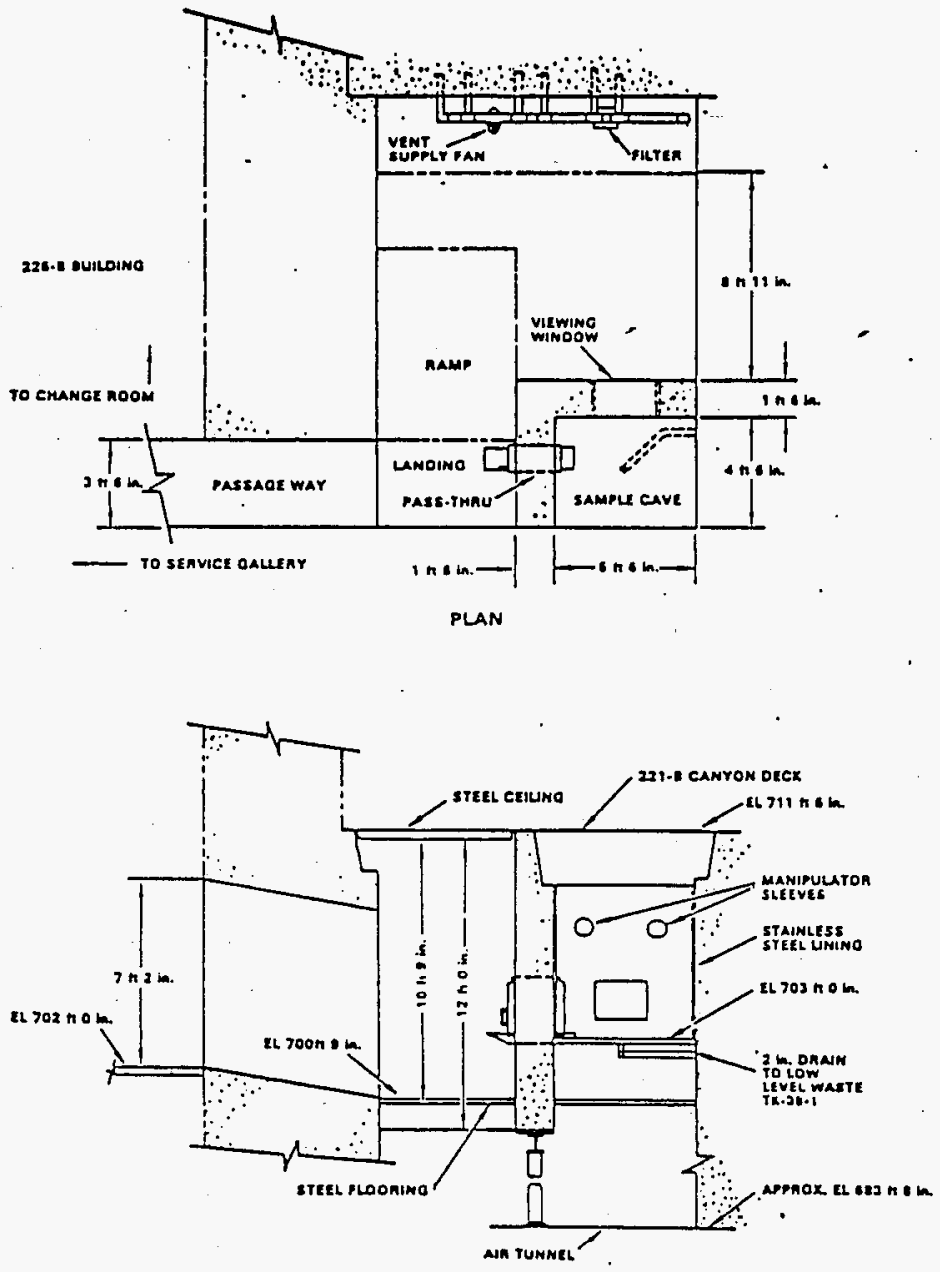

ELEVATION

Fesco1-33 
Figure 8. Hot Pipe Trench Cross Sections.
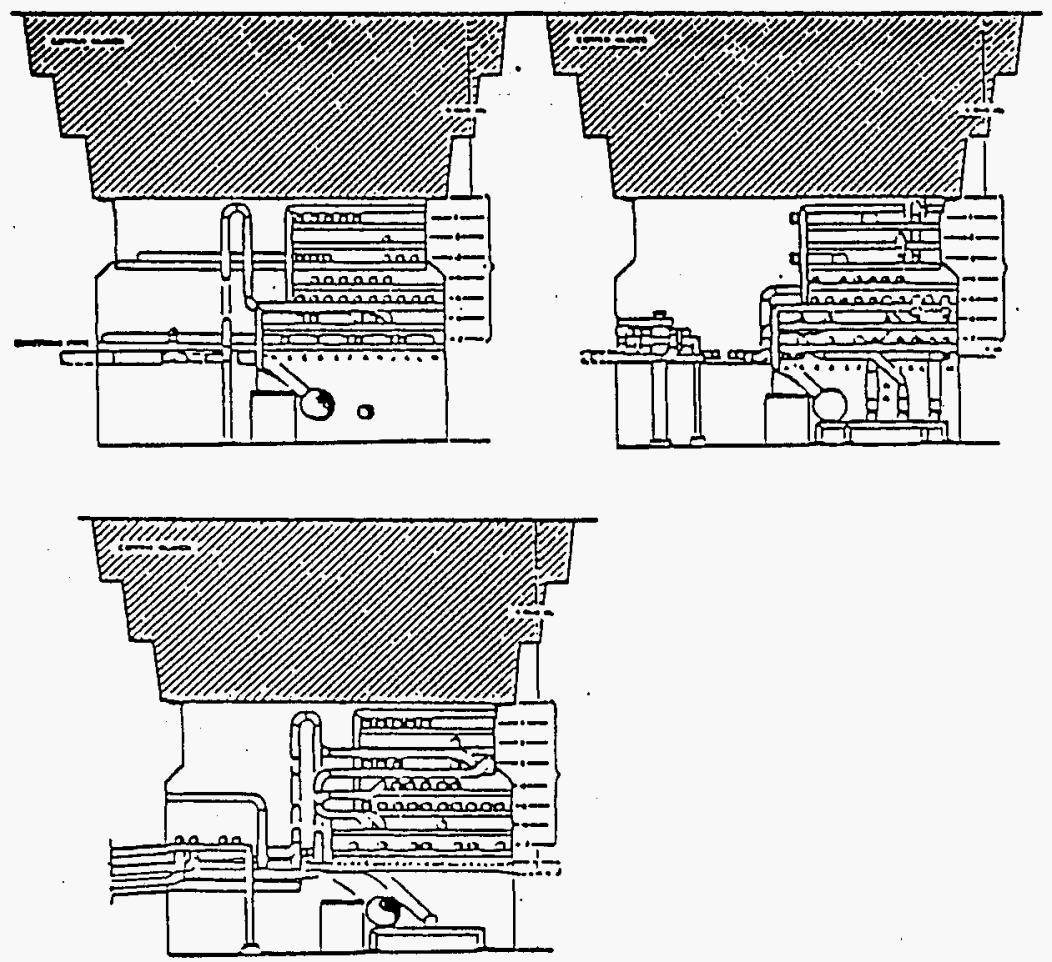
Figure 9. Canyon Exhaust Ventilation Duct.

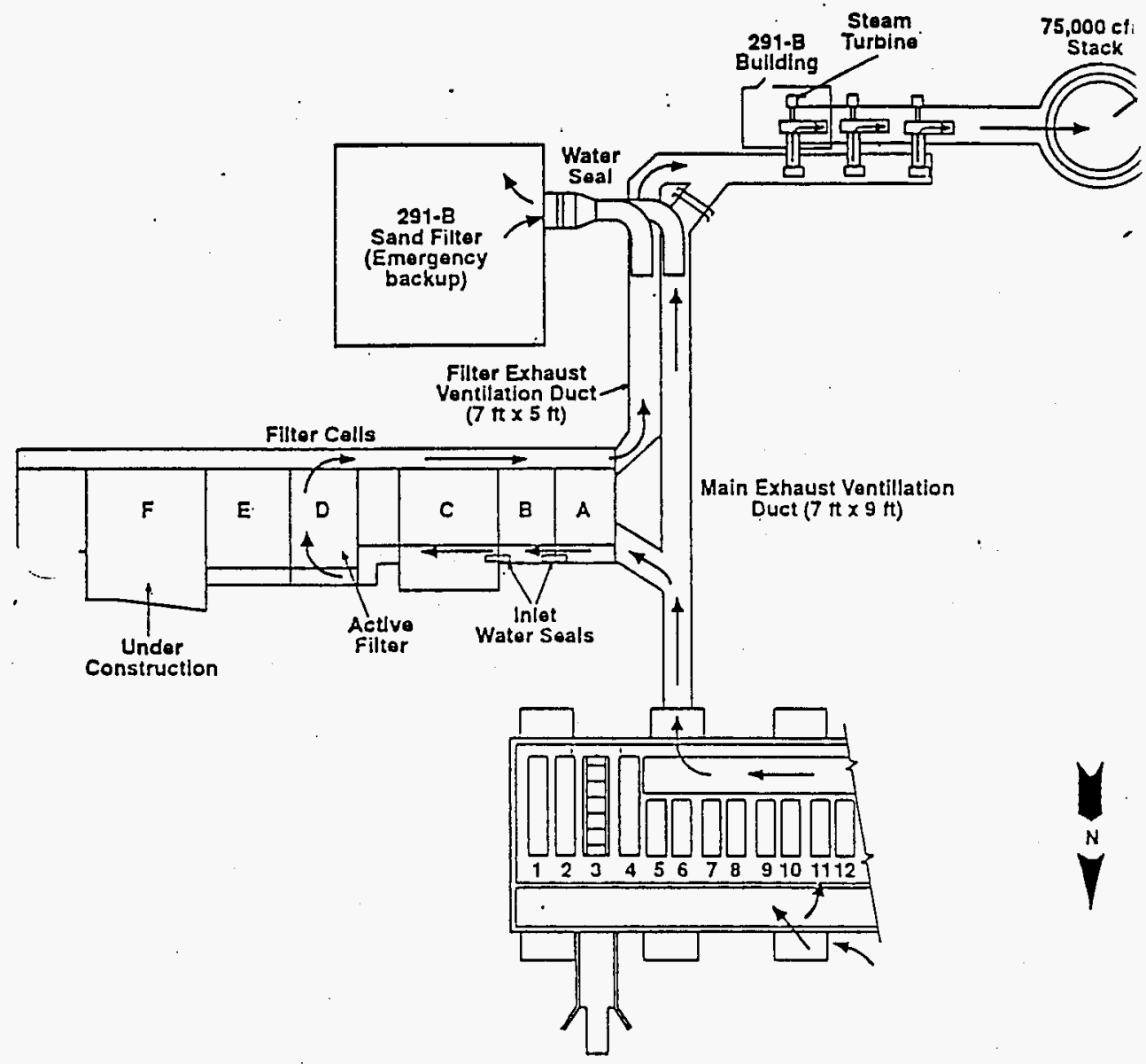


WHC-SD-WM-TM-004 REV 1

Figure 10. 212-B Cask Station.

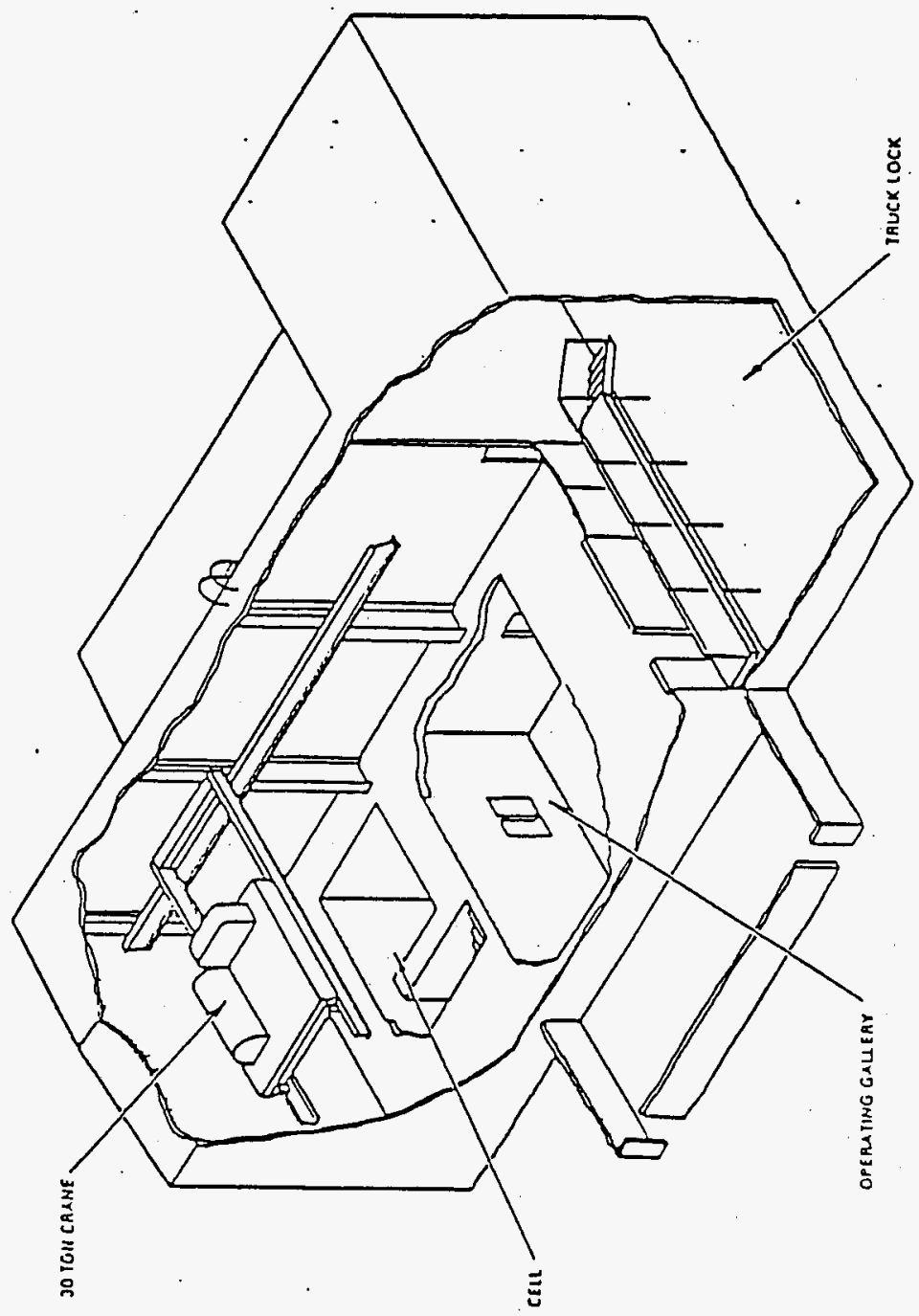


Figure 11. Ventilation Flow Pattern of the Gallery Ventilation System.
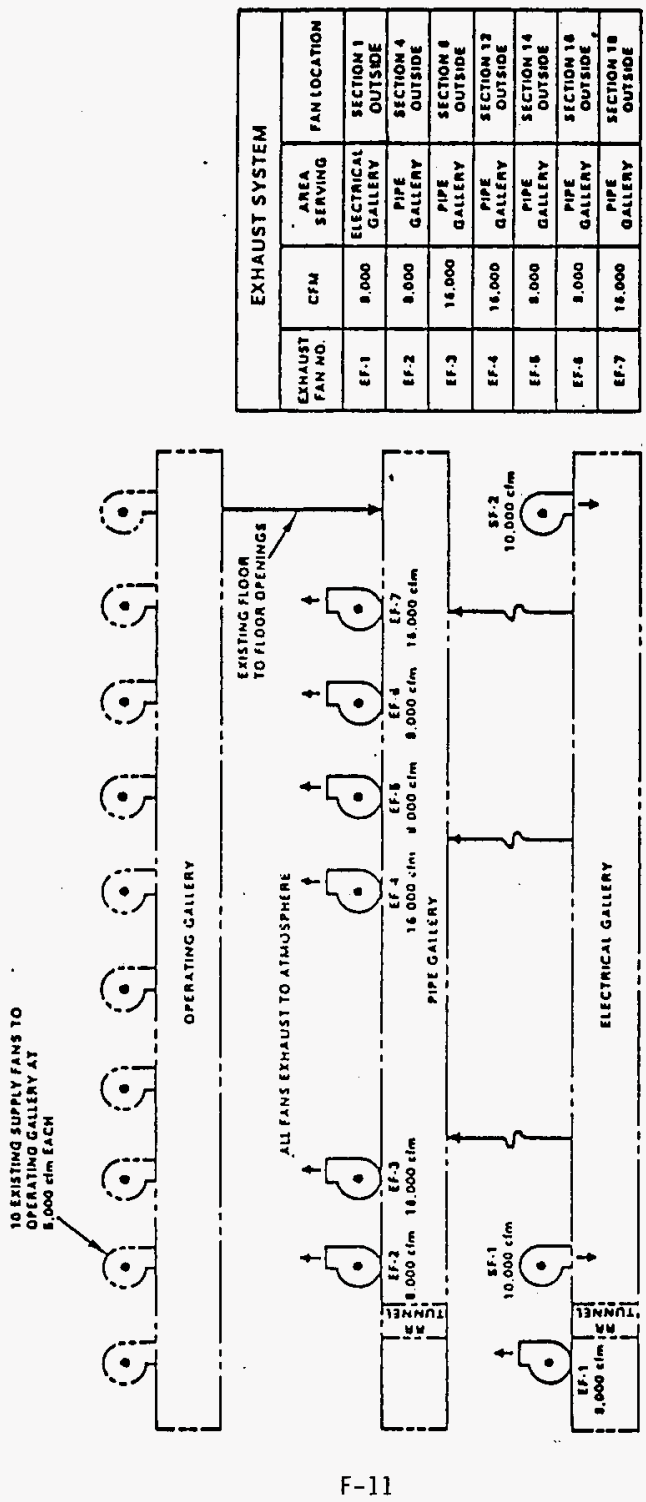
Figure 12. Electrical Gallery Supply System (Fans SF-1 and SF-2).

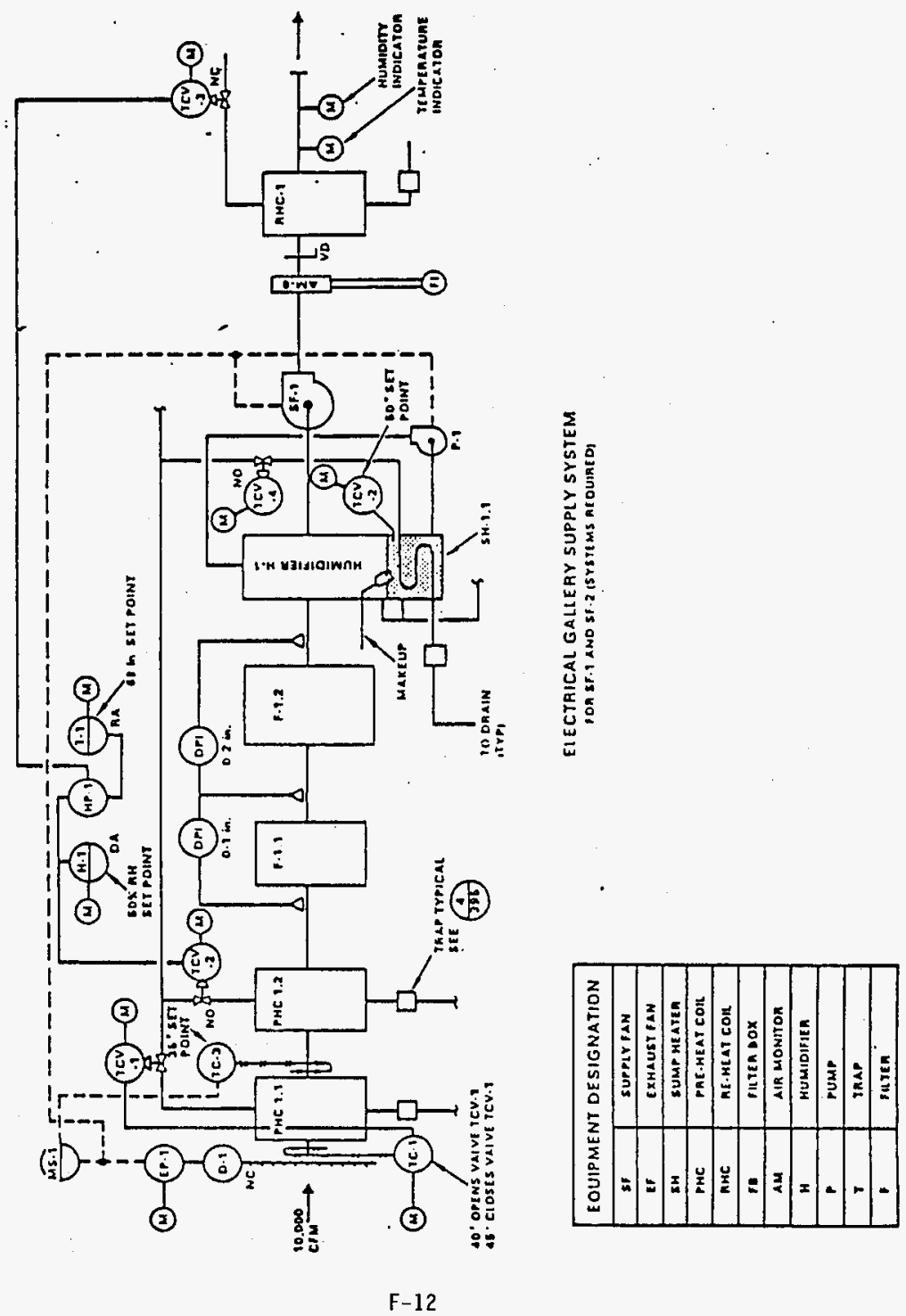


Figure 13. Pipe Gallery Exhaust System Fans (EF-1 through EF-7).
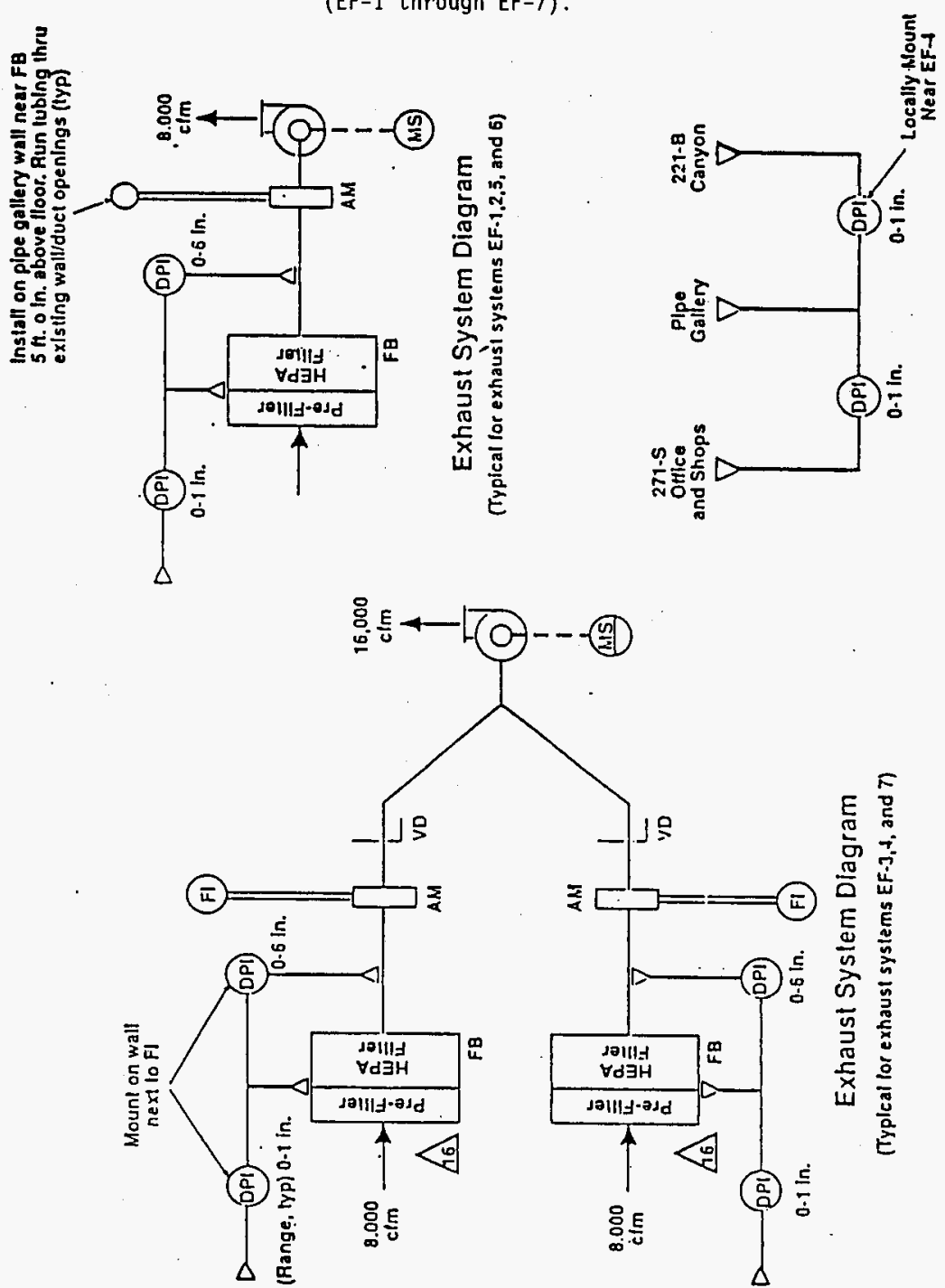<smiles>[CH]</smiles><smiles>CCCC</smiles> 
WHC-SD-WM-TM-004 REV 1

This page intentionally left blank.

F-14 


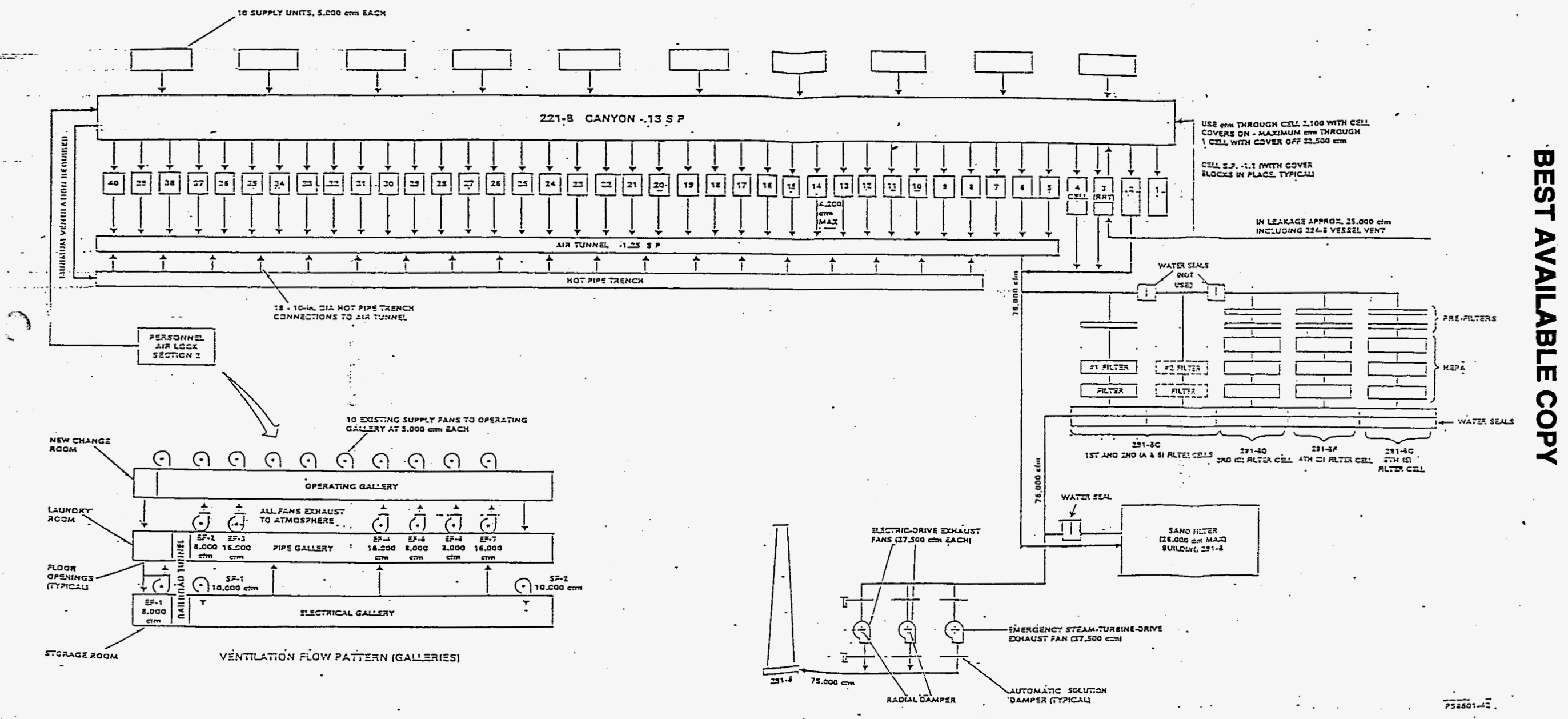


Figure 15. Ventilation Diagram of the B Plant Processing and Service Area.

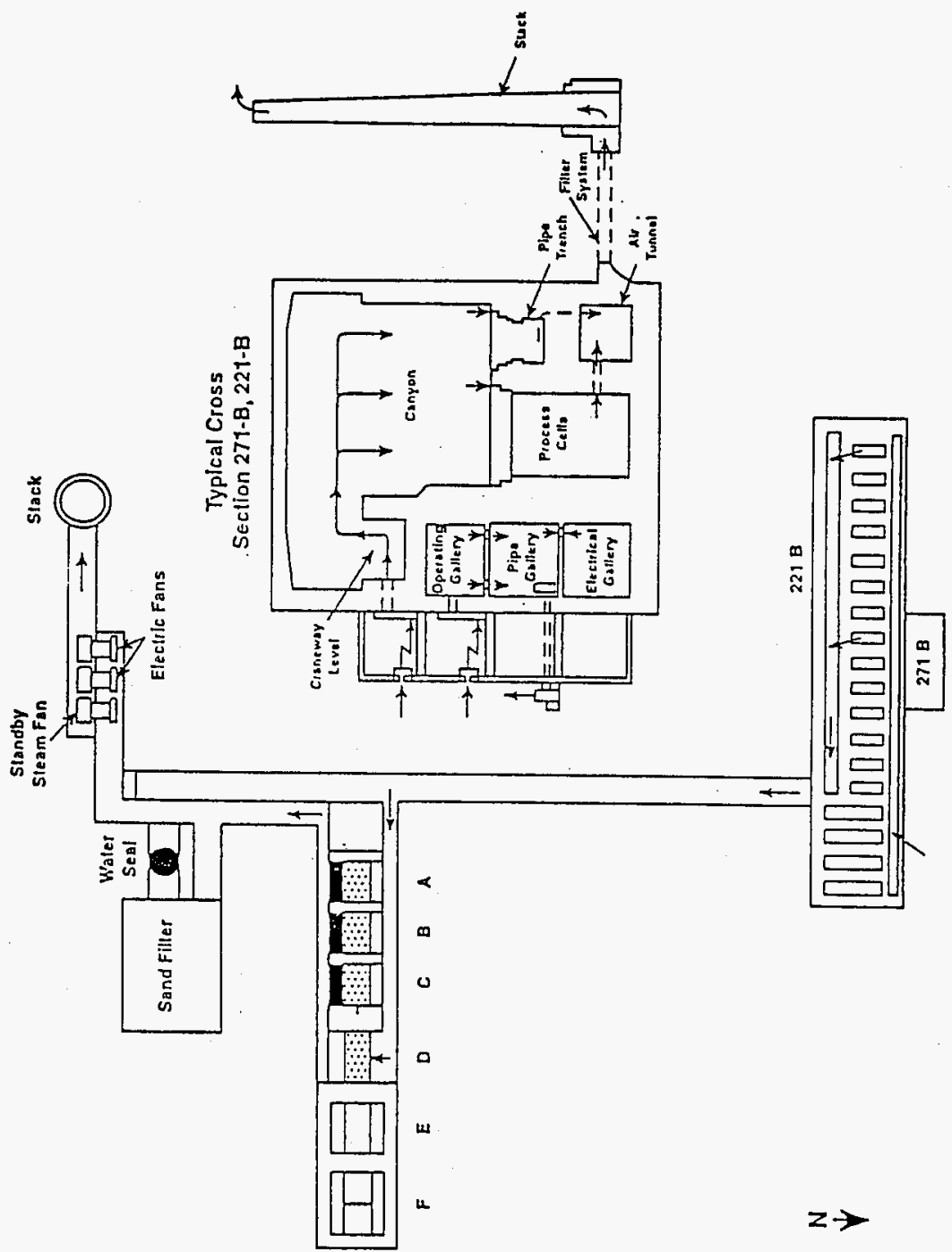


Figure 16. The 212-B Cask Station Ventilation System.

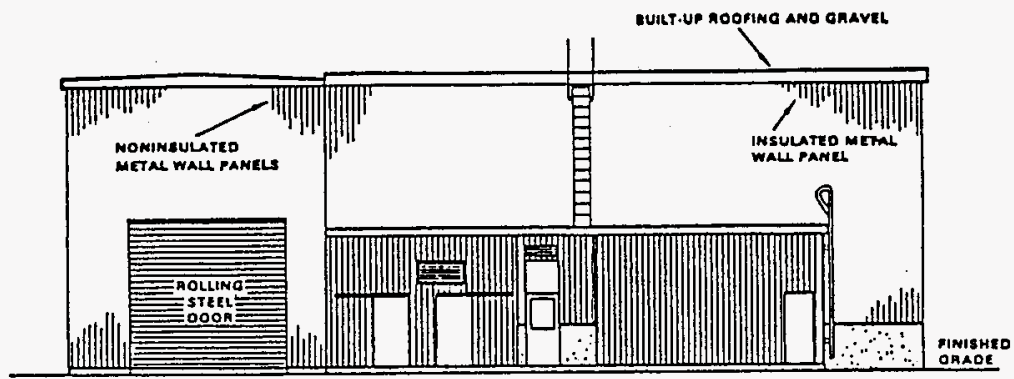

EAST ELEVATIOA
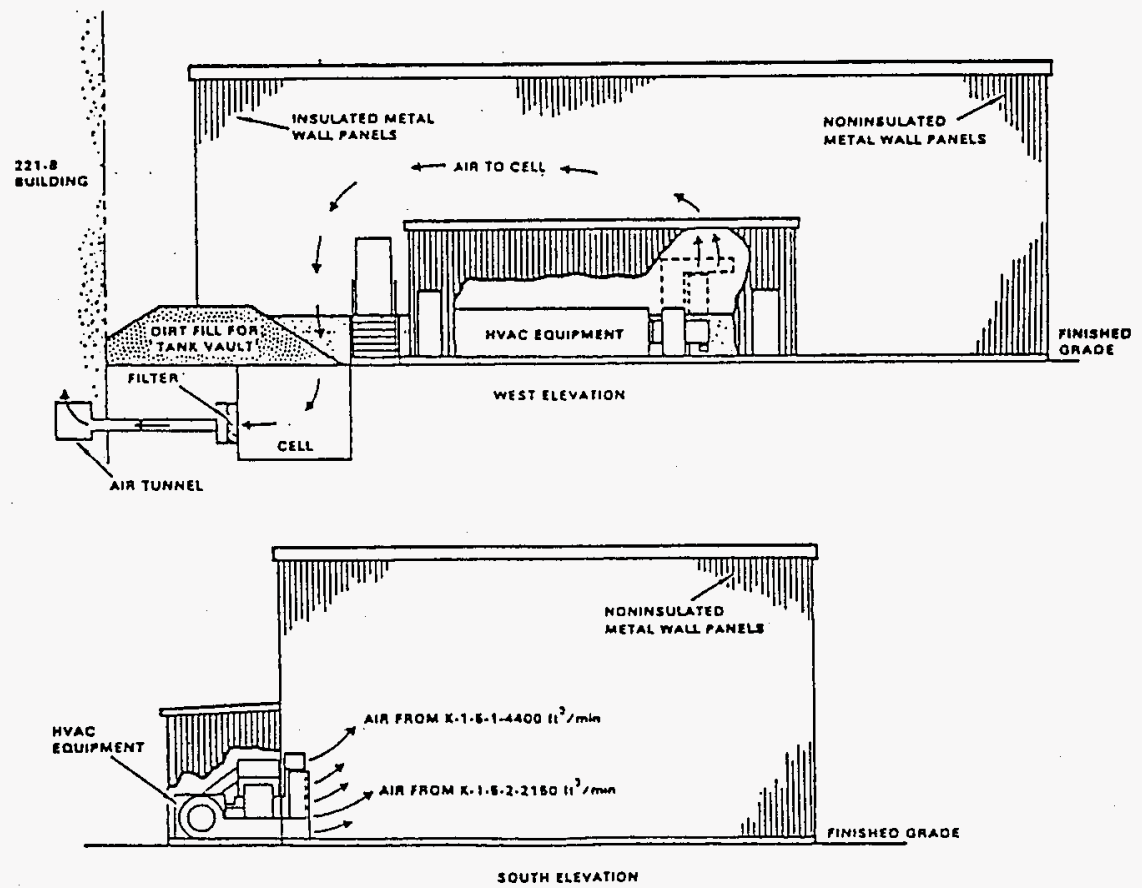

212.B BUILOING AIR FLOW 
Figure 17. The K2 System: 212-B Operating Gallery and Entrance Ventilation System.

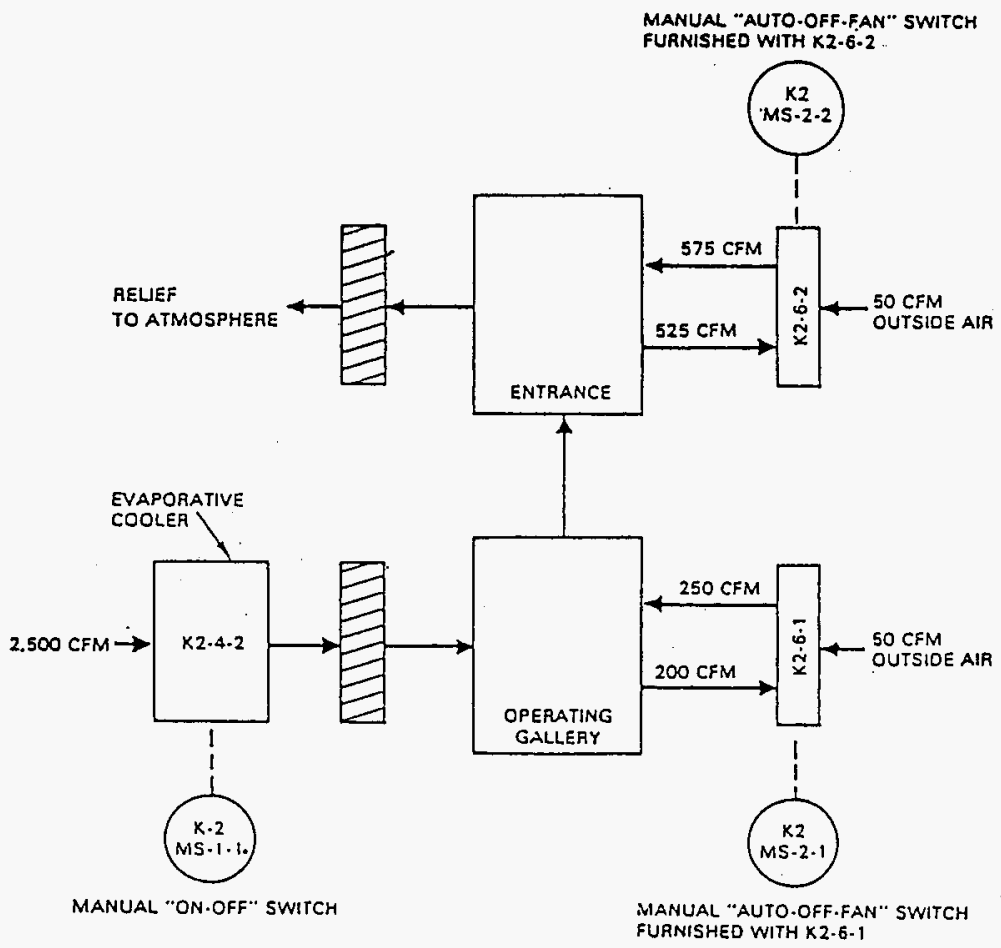

K2.SYSTEM

$155601 \cdot 24$ 
WHC-SD-WM-TM-004 REV 1

This page intentionally left blank. 

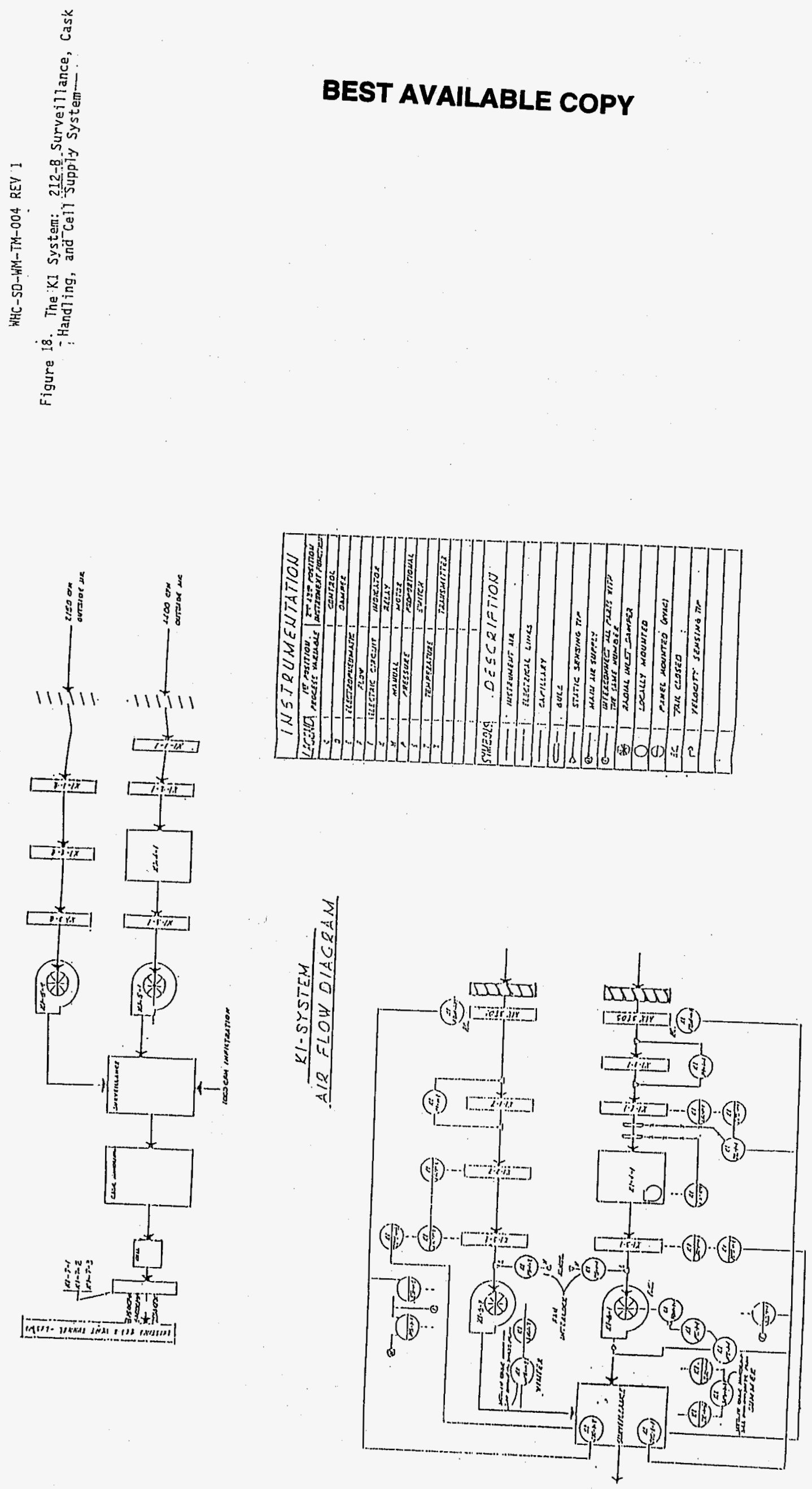

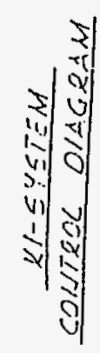




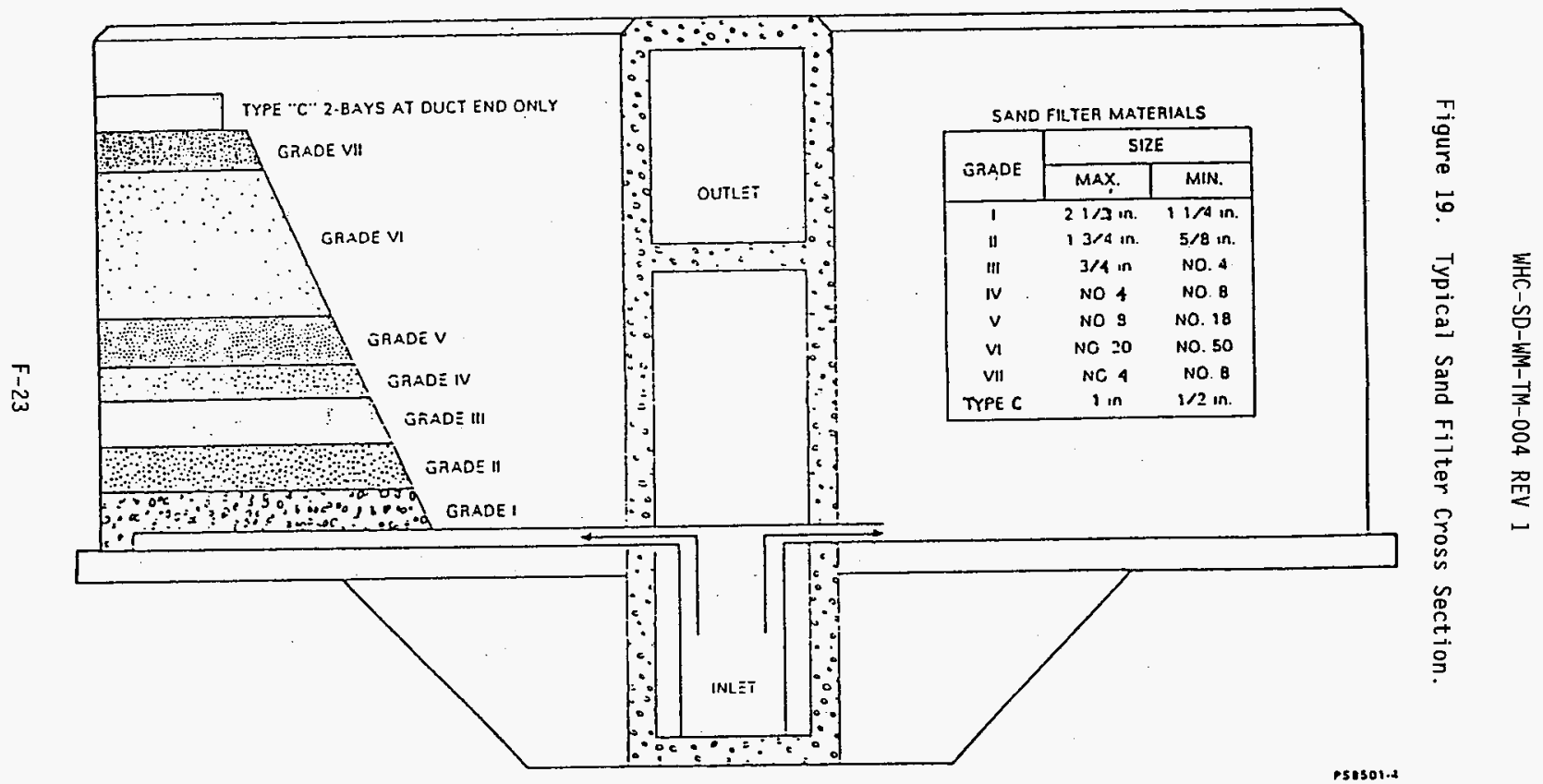


WHC-SD-WM-TM-004 REV 1

This page intentionally left blank. 


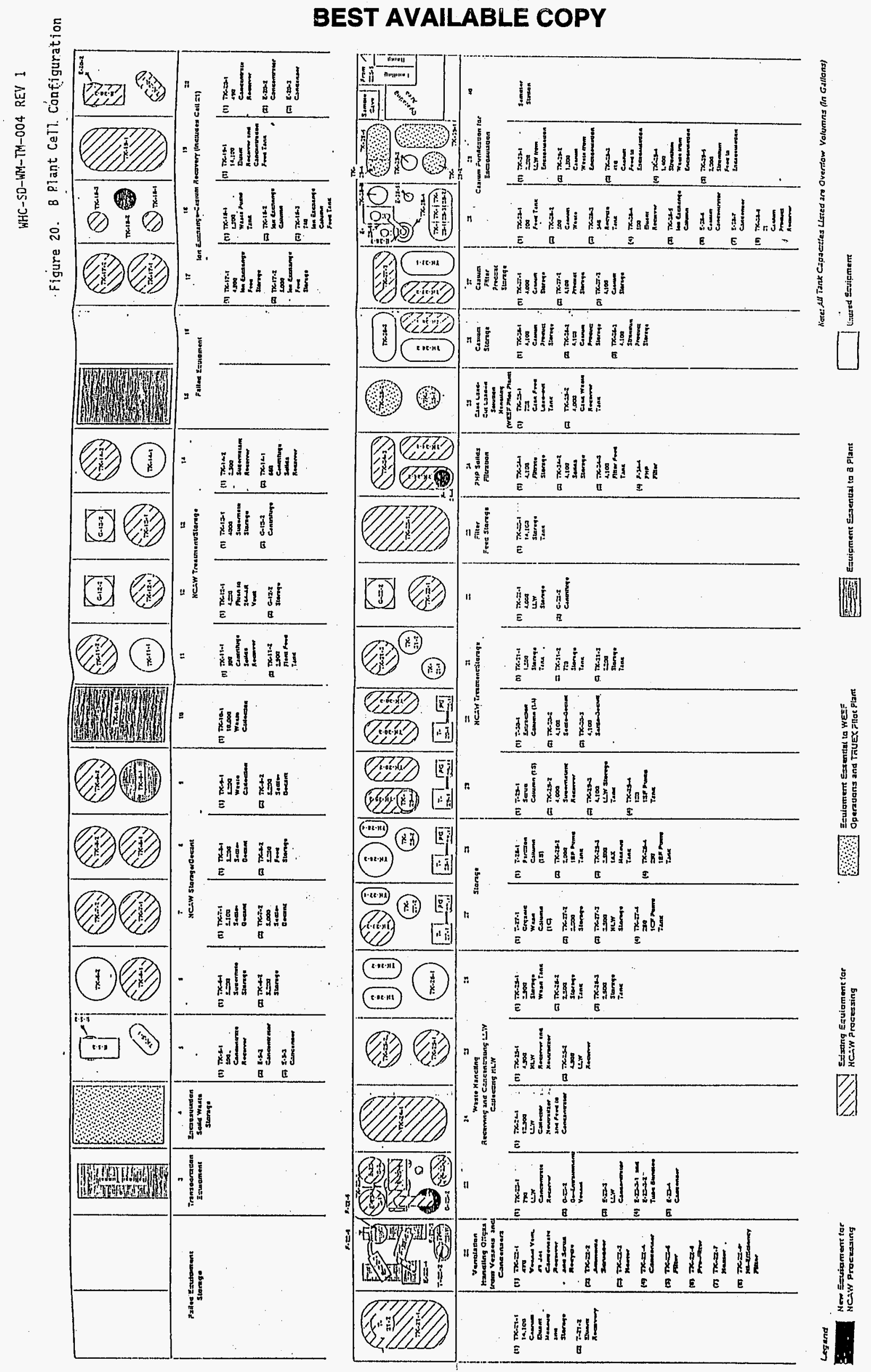


WHC-SD-WM-TM-004 REV 1

Figure 21. 211-BA Neutralization Facility.

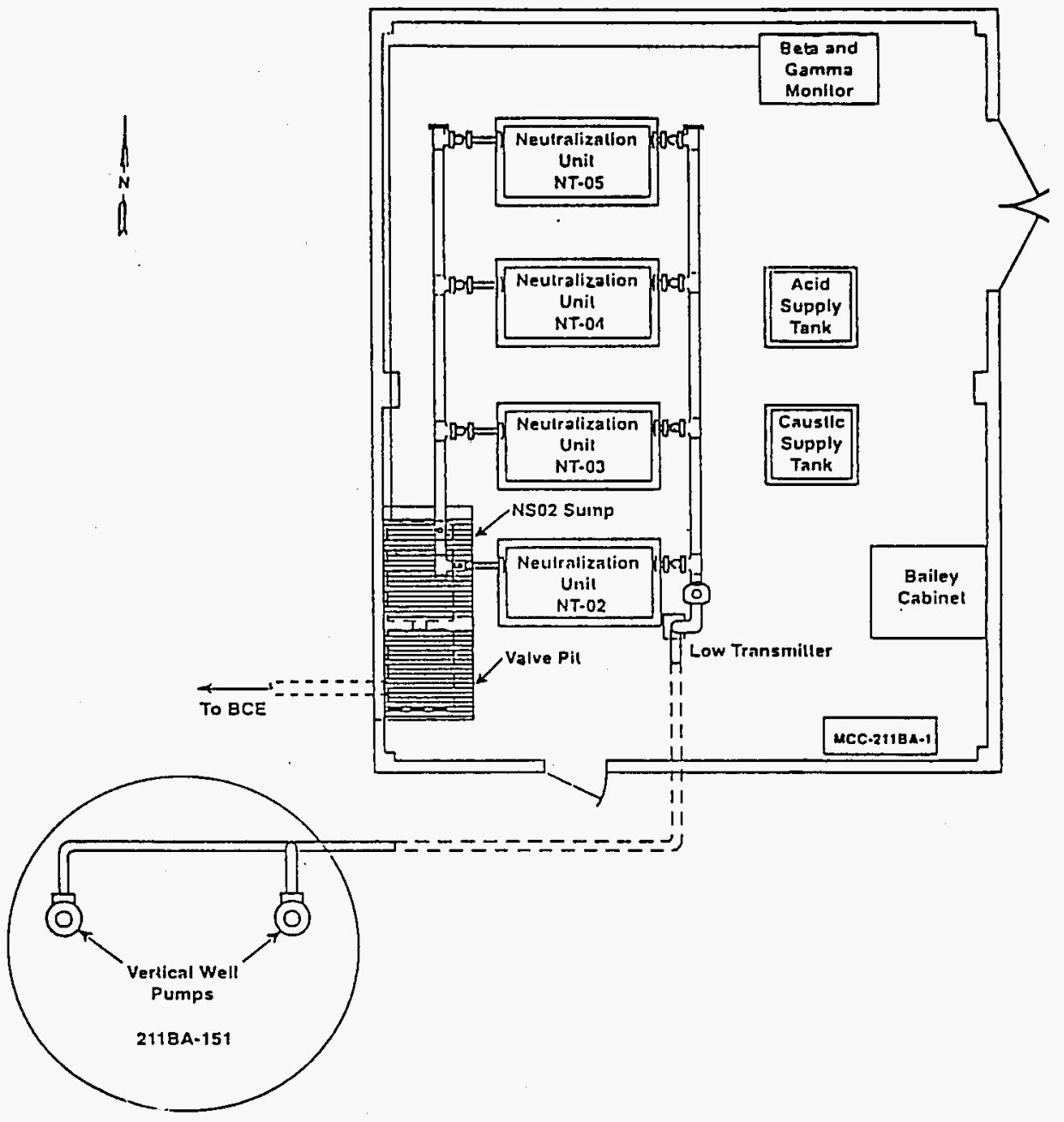


WHC-SD-WM-TM-004 REV 1

Figure 22. Chemical Storage Area Plot Plan.

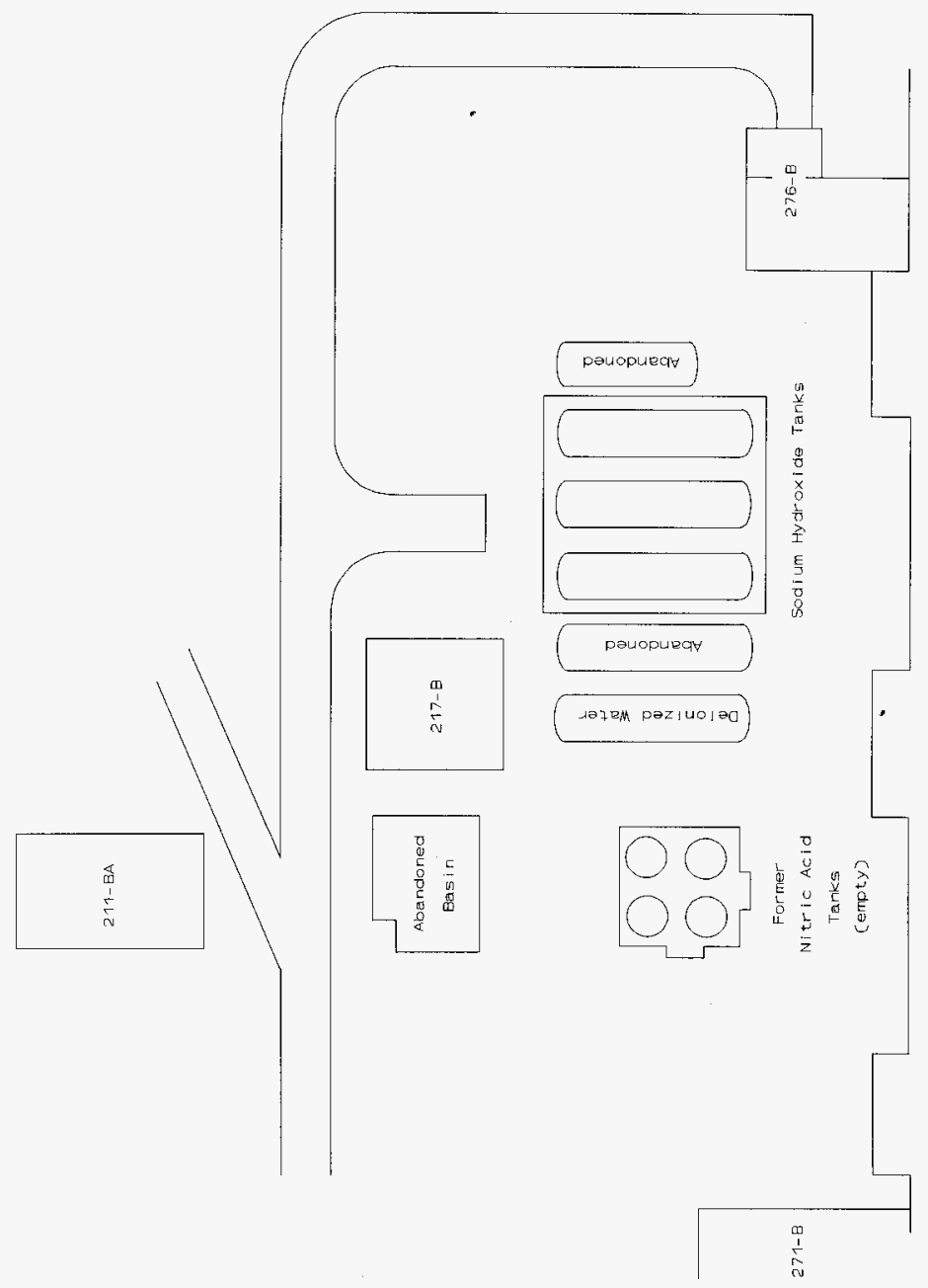


Table 1. Specific Buildings Within B Plant Facility.

(2 sheets)

\begin{tabular}{|c|c|}
\hline Identifier & Common name \\
\hline 1. 207-B & Retention Basin \\
\hline 2. 207-BA & CBC Sampling Building \\
\hline 3. $211-B$ & Chemical Tank Farm \\
\hline 4. 211-BA & Chemical Sewer Neutralization Facility \\
\hline 5. $212-B$ & Cask Transfer Station \\
\hline 6. $216-B$ & $\begin{array}{l}\text { Cribs } \\
\text { chemical sewer } \\
\text { - } 216-\mathrm{B}-62,221-\mathrm{B} \text { process condensate } \\
\text { - } 216-\mathrm{B}-55,221-\mathrm{B} \text { steam condensate }\end{array}$ \\
\hline 7. $217-B$ & Former Demineralized Water Facility \\
\hline 8. 218-B & Emergency Equipment Storage Shed \\
\hline 9. $219-\mathrm{B}$ & Emergency Equipment Storage Shed \\
\hline 10. 221-B & $\begin{array}{l}\text { B Plant Canyon } \\
\text { - Electrical gallery } \\
\text { - Pipe gallery } \\
\text { - Operating gallery } \\
\text { - Railroad tunnel }\end{array}$ \\
\hline 11. 221-BA & 15-in. Sewer Monitor Facility \\
\hline 12. 221-BB & Process Steam and Condensate Building \\
\hline 13. 221-BC & Change house and dumbwaiter \\
\hline 14. 221-BD & Laundry Storage Building \\
\hline 15. 221-BE & Fork Lift Storage Building \\
\hline 16. 221-BF & BCP Storage Pit \\
\hline 17. 221-BG & 24-in. Sewer Monitor Facility \\
\hline 18. $225-B$ & WESF \\
\hline 19. $226-B$ & Hazardous Waste Storage Area \\
\hline 20. 271-B & $\begin{array}{l}\text { B Plant support building } \\
\text { - Offices } \\
\text { - } \text { Distributive control system } \\
\text { - Third floor AMU } \\
\text { - Basement shops } \\
\text { Cold side ventilation equipment }\end{array}$ \\
\hline 21. 271-BA & Laundry Storage Building \\
\hline 22. $272-B$ & Electrical Shop \\
\hline 23. 272-BA & Maintenance Storage \\
\hline
\end{tabular}


Table 1. Specific Buildings Within B Plant Facility.

(2 sheets)

\begin{tabular}{|c|c|}
\hline Identifier & Common name \\
\hline 24. 272-BB & Insulation Shop \\
\hline 25. $276-B$ & Paint Shop \\
\hline 26. 282-B & Emergency Water Pump House \\
\hline 27. 282-BA & Emergency Water Pump House \\
\hline 28. 291-B & Main stack/sand filter/turbine building \\
\hline 29. 291-BA & Exhaust Air Sample House \\
\hline 30. 291-BB & Instrument Building - A and B filters \\
\hline 31. 291-BC & $A$ and $B$ filters \\
\hline 32. $291-\mathrm{BD}$ & C filter and Instrument Building \\
\hline 33. 291-BF & D filter and Instrument Building \\
\hline 34. 291-BG & E filter Instrument Building \\
\hline 35. 291-BH & E filter \\
\hline 36. $291-\mathrm{BJ}$ & F filter \\
\hline 37. 292-B & Stack Monitoring Station \\
\hline 38. 294-B & Back flow Preventer Building \\
\hline 39. $2711-\mathrm{B}$ & Breathing Air Compressor House \\
\hline 40. $2711-B A$ & Breathing Air Compressor WESF \\
\hline 41. 2712-B & Electrical Instrumentation Building \\
\hline 42. $2715-B$ & Paint Storage Building \\
\hline 43. $2716-B$ & Laundry storage - railroad tunnel \\
\hline 44. $2902-B$ & Emergency sanitary water supply tank \\
\hline 45. 2904-EA & Chemical Sewer Sampling Building \\
\hline 46. $M 0-029$ & Office trailer \\
\hline 47. MO-232 & Office trailer \\
\hline 48. MO-400 & office trailer \\
\hline 49. MO-408 & Office trailer \\
\hline 50. MO-410 & office trailer \\
\hline 51. MO-995 & Office trailer \\
\hline
\end{tabular}

AMU $=$ aqueous makeup unit.

$B C P=B$ Plant process condensate.

$\mathrm{CBC}=\mathrm{B}$ Plant cooling water.

WESF = Waste Encapsulation and storage Facility. 
Table 2. Canyon Tanks Information.

\begin{tabular}{|c|l|c|c|}
\hline Tank number & \multicolumn{1}{|c|}{ Function } & $\begin{array}{c}\text { Dimensions } \\
(\mathrm{ft} / \text { diameter })^{\mathrm{a}}\end{array}$ & $\begin{array}{c}\text { Capacity } \\
(\mathrm{ga} 1)^{\mathrm{b}}\end{array}$ \\
\hline $9-1$ & Low-level waste & 8 by 14 & $5,200.0$ \\
\hline $10-1$ & Low-level waste & 18 by 11 by 7 & $10,000.0$ \\
\hline $22-1$ & Condensate receiver & 3.25 by 7 by 4 & 460.9 \\
\hline $24-1$ & Low-level waste & 10 by 16 by 14 & $11,090.0$ \\
\hline $25-2$ & Aqueous & & $4,879.9$ \\
\hline $26-1$ & Organic & 9 by 9 & $3,932.1$ \\
\hline $26-3$ & Organic/aqueous & & $2,621.3$ \\
\hline $27-2$ & Organic/aqueous & 7 by 14 & $2,002.4$ \\
\hline $27-3$ & Organics & 7 by 14 & $3,790.0$ \\
\hline $28-3$ & Organics & 9.5 by 5 by 14 & $3,987.4$ \\
\hline $29-2$ & Low-level waste & 9.5 by 5 by 14 & $4,135.5$ \\
\hline $30-3$ & Organics & 5.5 by 9 by 14 & $4,400.0$ \\
\hline $36-1$ & Flush water & 9.5 by 5 by 12 & $3,700.0$ \\
\hline $39-1$ & Low-level waste & &
\end{tabular}

a To convert feet to meters, multiply by 0.3048 .

To convert gallons to liters, mult iply by 3.7854 . 
Table 3. Chemical Storage Tanks in 211-B.

\begin{tabular}{|c|c|c|c|c|c|}
\hline \multicolumn{1}{|c|}{ Chemical } & \multicolumn{2}{|c|}{ Tank } & \multicolumn{2}{|c|}{ Pump } & \multirow{2}{*}{ Drawing } \\
\hline Stored & Number & $\begin{array}{c}\text { Max Volume } \\
\text { gal }\end{array}$ & Number & Header & H-2-36123 \\
\hline 1. Deionized water & TK-SD-111 & 18,000 & $2118-$ PSD-1 & DH-111 & Th \\
\hline
\end{tabular}

*To convert gal to $L$, multiply by 3.7854 . 
Table 4. Chemical Headers to Operating Gallery Scale Tanks. (Swanson 1986)

\begin{tabular}{|c|c|c|}
\hline Scale tank & Chemical headers & Cell tanks \\
\hline$T K-5 B$ & 111 No. 1 & None \\
\hline TK-5A & 111 No. 1 & None \\
\hline TK-6A & 111 No. 1 & $6-1,6-2$ \\
\hline TK-7A & 111 No. 1 & $7-1,7-1$ \\
\hline $\mathrm{TK}-8 \mathrm{~A}$ & 111 No. 1; H313,314; H309,312 & 8-1, 8-2 \\
\hline TK-9A & 111 No. 1; H313,314; H309,312 & $9-1,9-2$ \\
\hline TK-11C & 111 No. 1 & $11-2$ \\
\hline TK-11B & $\begin{array}{l}111 \text { No.1; H313,314; H309,312; } \mathrm{H3} 10,311 \\
\mathrm{H305}, \mathrm{H} 303,304\end{array}$ & $11-1,11-2,12-2$ \\
\hline IK-11A & 111 No. 1 & $11-1,11-2,12-2$ \\
\hline$T K-12 A$ & 111 No. 1 & $12-2$ \\
\hline IK-14B & 111 No. 1 & $13-1,14-2$ \\
\hline IK-13B & 111 No.1 & $13-2$ \\
\hline TK-13A & 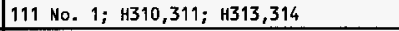 & None \\
\hline IK-14A & 111 No. 1 & $14-1$ \\
\hline IK-15A & 111 No. $1 ; \mathrm{H} 313,314$ & $22-2,23-2$ \\
\hline TK-17A & 111 No. 1 & $17-1,17-2,18-1$ \\
\hline TK-18A & $1 \uparrow 1$ No. 1 & None \\
\hline IK-19A & 111 No. $1 ;$ H313,314 & 19-1 \\
\hline TK-20A & 111 No. 1 & $20-1,20-2$ \\
\hline TK-23A & 111 No. $1 ; \mathrm{H} 313,314 ; \mathrm{H} 310,311$ & $23-1,23-3,22-1$ \\
\hline IK-24A & 111 No. $1 ; \mathrm{H} 310,311 ; \mathrm{H3} 13,314$ & $24-1,25-2$ \\
\hline TK-25A & 111 No. $1 ; \mathrm{H} 310,311 ; \mathrm{H} 315,316$ & $25-2,24-1$ \\
\hline$T K-26 A$ & 111 No.1; H310,311 & 26-1 \\
\hline IK-26B & 111 No.1; H310,311; & $26-2,26-3$ \\
\hline TK-28C & 111 No. $1 ;$ H310,311; & $28-3$ \\
\hline IK-28A & 111 No. 1 & $28-1$ \\
\hline $\mathrm{TK}-2 \mathrm{BB}$ & $\uparrow 11$ No. 1 & $28-2,27-2$ or $28-4,27-4$ \\
\hline IK-29A & 111 No. 1; H313,314 (isolated) & 29-1 \\
\hline TK-29D & 111 No. $1 ; \mathrm{H310}, 311$ & $29-3,29-2$ \\
\hline TK-29B & 111 No. $1 ; H 310,311$ & $29-2$ \\
\hline$T K-29 C$ & 111 No. 1 & $29-2$ \\
\hline $\mathrm{TK}-30 \mathrm{~A}$ & 111 No. 1 & $30-1,30-2$ \\
\hline TK-31B & 111 No. $1 ;$ H313,314 & $31-1,31-3$ \\
\hline TK-31A & 111 No. $1 ; \mathrm{H} 313,314 ; \mathrm{H} 310,311$ & $31-1,31-2,31-3$ \\
\hline $\mathrm{TK}-31 \mathrm{C}$ & 111 No. $1 ;$ H309,312 & $31-3,31-1,31-2$ \\
\hline TK-32A & $111 \mathrm{No} .1 ; \mathrm{H313}, 314 ; \mathrm{H310}, 311$ & $32-1,33-1$ \\
\hline $\mathrm{TK}-32 \mathrm{~B}$ & 111 No.1; H313,314; H309,312; H310,311 & $G-32-2$ \\
\hline TK-34A & 111 No. 1; H313,314; H309, 312 & $34-1,34-2,34-3$ \\
\hline TK-35A & 111 No.1; H313,314; H309,312; H310,311 & $35-1,35-2,2-25 \mathrm{cs}-1$ \\
\hline TK-37A & 111 No. 1 & $37-1,37-2,37-3$ \\
\hline TK $-36 \mathrm{~A}$ & 111 No. $1 ; \mathrm{H} 309,312$ & $36-1,36-2$ \\
\hline$T K-36 B$ & 111 No. 1; H309,312 & $36-3$ \\
\hline TK-38A & 111 No.1; H309,312; H310,311; H313,314 & $38-1,38-2,38-3,39-1,39-2,39-4, E-38-7$ \\
\hline TK-39A & 111 No.1; H309,312; H313,314 & $37-1,37-2,39-3,39-5, E-38-6$, Cell $40,38-8$ \\
\hline
\end{tabular}


Table 5. Aqueous Makeup Tanks.

\begin{tabular}{|l|c|c|c|}
\hline \multicolumn{1}{|c|}{ Tank } & $\begin{array}{c}\text { Capacity } \\
(\mathrm{gal})^{\mathrm{a}}\end{array}$ & $\begin{array}{c}\text { Coils cooling } \\
\text { area }_{\left(\mathrm{ft}^{2}\right)^{\mathrm{b}}}\end{array}$ & $\begin{array}{c}\text { Duty } \\
(\mathrm{Btu} / \mathrm{h})\end{array}$ \\
\hline $\mathrm{H}-309$ & 600 & -- & -- \\
\hline $\mathrm{H}-310$ & 600 & -- & -- \\
\hline $\mathrm{H}-311$ & 600 & -- & -- \\
\hline $\mathrm{H}-312^{\mathrm{c}}$ & 600 & 12 & $1.0 \times 10^{5}$ \\
\hline $\mathrm{H}-313^{\mathrm{c}}$ & 600 & 13.5 & $3.0 \times 10^{5}$ \\
\hline $\mathrm{H}-314^{\mathrm{c}}$ & 600 & 13.5 & $3.0 \times 10^{5}$ \\
\hline $\mathrm{H}-315^{\mathrm{c}}$ & 600 & 27 & $2.5 \times 10^{5}$ \\
\hline $\mathrm{H}-316^{\mathrm{c}}$ & 600 & 27 & $2.5 \times 10^{5}$ \\
\hline $\mathrm{H}-101$ & 1000 & 35 & $2.5 \times 10^{5}$ \\
\hline $\mathrm{H}-102$ & 2500 & 25 & $1.0 \times 10^{5}$ \\
\hline
\end{tabular}

a $_{\text {To }}$ convert gal to $L_{2}$ multiply by 3.7854 .

bo convert $\mathrm{ft}^{2}$ to $\mathrm{m}^{2}$, multiply by 0.0929 .

Tanks with agitators. 


\section{DISTRIBUTION SHEET}

\begin{tabular}{|c|c|c|c|c|c|}
\hline \multirow{2}{*}{$\begin{array}{l}\text { To } \\
\text { Distribution }\end{array}$} & \multirow{2}{*}{\multicolumn{3}{|c|}{$\begin{array}{l}\text { From } \\
\text { S.E. Chalk }\end{array}$}} & \multicolumn{2}{|c|}{ Page 1 of 1} \\
\hline & & & & \multicolumn{2}{|c|}{ Date $7 / 12 / 96$} \\
\hline \multirow{2}{*}{\multicolumn{4}{|c|}{$\begin{array}{l}\text { Project Title/Work Order } \\
\text { B Plant ISB Facility Description, WHC-SD-WM-TM-004, Rev. } 1\end{array}$}} & \multicolumn{2}{|c|}{ EDT No. $\quad N / A$} \\
\hline & & & & \multicolumn{2}{|c|}{ ECN No. 632050} \\
\hline Name & MSIN & $\begin{array}{c}\text { Text } \\
\text { With All } \\
\text { Attach. }\end{array}$ & Text Only & $\begin{array}{c}\text { Attach. } \\
\text { Appendi } \\
\text { Only }\end{array}$ & $\begin{array}{l}\text { EDT/ECN } \\
\text { Only }\end{array}$ \\
\hline
\end{tabular}

Correspondence Control

Bliss

S. D. Godfrey

R. E. Heineman, Jr.

W. A. Holstein

B. H. Lueck

J. C. Midgett

P. E. Roege

D. K. Smith

D. W. Wilson

A. B. Rau

S. E. Chalk

M. K. Ullah

M. A. Hill

S. E. Killoy

G. L. McCormick

J. E. Mecca

R. J. Cash

Central filea (origti)

$\begin{array}{ll}\text { A3-01 } & X \\ \text { B3-04 } & \\ \text { S6-70 } & \\ \text { S6-65 } & X \\ \text { S6-65 } & \\ \text { S6-62 } & \\ \text { S6-65 } & X \\ \text { S6-81 } & X \\ \text { S6-60 } & X \\ \text { S6-70 } & \\ \text { A2-25 } & X \\ \text { A2-25 } & X \\ \text { S6-69 } & X \\ \text { S4-69 } & X \\ \text { S4-66 } & X \\ \text { H5-31 } & X \\ \text { R3-79 } & \\ \text { S7-14 } & \\ \text { A3 - 8 } & X\end{array}$

$\hat{x}$

$x$

A3-01

$x$

$x$

$x$$$
\text { X }
$$

$X$

$x$

$X$

$X$

$x$
$x$ 